\title{
CAMA
}

Centre for Applied Macroeconomic Analysis

\section{A Cross-Country Database of Fiscal Space}

\section{CAMA Working Paper 48/2017 August 2017}

\section{Ayhan Kose}

Development Prospects Group, World Bank

Brookings Institution

CEPR and

Centre for Applied Macroeconomic Analysis, ANU

\section{Sergio Kurlat}

Development Prospects Group, World Bank

\section{Franziska Ohnsorge}

Development Prospects Group, World Bank and

Centre for Applied Macroeconomic Analysis, ANU

\section{Naotaka Sugawara}

Development Prospects Group, World Bank 


\section{Abstract}

This paper presents a comprehensive cross-country database of fiscal space, broadly defined as the availability of budgetary resources for a government to service its financial obligations. The database covers up to 200 countries over the period 1990-2016, and includes 28 indicators of fiscal space grouped into four categories: debt sustainability, balance sheet vulnerability, external and private sector debt related risks as potential causes of contingent liabilities, and market access. We illustrate potential applications of the database by analyzing developments in fiscal space across three time frames: over the past quarter century; during financial crises; and during oil price plunges. The main results are as follows. First, fiscal space had improved in many countries before the global financial crisis. In advanced economies, following severe deteriorations during the crisis, many indicators of fiscal space have virtually returned to levels in the mid-2000s. In contrast, fiscal space has shrunk in many emerging market and developing economies since the crisis. Second, financial crises tend to coincide with deterioration in multiple indicators of fiscal space, but they are often followed by reduced reliance on short-term borrowing. Finally, fiscal space narrows in energy-exporting emerging market and developing economies during oil price plunges but later expands, often because of procyclical fiscal tightening and, in some episodes, a recovery in oil prices.

\section{Keywords}

Fiscal policy, sovereign debt, fiscal deficit, private debt, financial crises, oil prices.

\section{JEL Classification}

E62, H62, H63

\section{Address for correspondence:}

(E) cama.admin@anu.edu.au

ISSN 2206-0332

The Centre for Applied Macroeconomic Analysis in the Crawford School of Public Policy has been established to build strong links between professional macroeconomists. It provides a forum for quality macroeconomic research and discussion of policy issues between academia, government and the private sector.

The Crawford School of Public Policy is the Australian National University's public policy school, serving and influencing Australia, Asia and the Pacific through advanced policy research, graduate and executive education, and policy impact. 


\title{
A Cross-Country Database of Fiscal Space
}

\author{
M. Ayhan Kose, Sergio Kurlat, Franziska Ohnsorge, and Naotaka Sugawara*
}

August 2017

\begin{abstract}
This paper presents a comprehensive cross-country database of fiscal space, broadly defined as the availability of budgetary resources for a government to service its financial obligations. The database covers up to 200 countries over the period 1990-2016, and includes 28 indicators of fiscal space grouped into four categories: debt sustainability, balance sheet vulnerability, external and private sector debt related risks as potential causes of contingent liabilities, and market access. We illustrate potential applications of the database by analyzing developments in fiscal space across three time frames: over the past quarter century; during financial crises; and during oil price plunges. The main results are as follows. First, fiscal space had improved in many countries before the global financial crisis. In advanced economies, following severe deteriorations during the crisis, many indicators of fiscal space have virtually returned to levels in the mid2000s. In contrast, fiscal space has shrunk in many emerging market and developing economies since the crisis. Second, financial crises tend to coincide with deterioration in multiple indicators of fiscal space, but they are often followed by reduced reliance on short-term borrowing. Finally, fiscal space narrows in energy-exporting emerging market and developing economies during oil price plunges but later expands, often because of procyclical fiscal tightening and, in some episodes, a recovery in oil prices.
\end{abstract}

Key Words: Fiscal policy; sovereign debt; fiscal deficit; private debt; financial crises; oil prices. JEL Codes: E62; H62; H63.

\footnotetext{
${ }^{*}$ Kose (Development Prospects Group, World Bank; Brookings Institution; CEPR; CAMA; akose@worldbank.org); Ohnsorge (Development Prospects Group, World Bank; CAMA; fohnsorge@worldbank.org); Sugawara (Development Prospects Group, World Bank; nsugawara@worldbank.org). Kurlat was a consultant at the Development Prospects Group when the early analysis was conducted for this study. We would like to thank Carlos Arteta, Eduardo Borenzstein, Kevin Clinton, Raphael Espinoza, Raju Huidrom, Anna Ivanova, Ugo Panizza, Evis Rucaj, Marc Stocker, Carlos Végh, Dana Vorisek and seminar participants at the World Bank for valuable comments, and Graeme Littler and Praveen Penmetsa for developing the database web interface. Xinghao Gong provided excellent research assistance. The findings, interpretations and conclusions expressed in this paper are entirely those of the authors and should not be attributed to the World Bank, its Executive Directors, or the countries they represent. The database is available at: http://www.worldbank.org/en/research/brief/fiscal-space.
} 


\section{Introduction}

The need for support to economic activity in the aftermath of the global financial crisis presented a painful reminder of the importance of a government's ability to implement effective fiscal stimulus. This ability is ultimately predicated on the availability of fiscal space. Ample fiscal space provides a government with the necessary budgetary resources to stimulate activity. Just as important, it provides credibility about the sustainability of the budget, and thereby helps to ensure that fiscal stimulus is effective in promoting growth. ${ }^{1}$ The availability of fiscal space has also been at the center of recent debates on the deployment of fiscal policy to accelerate growth in advanced and developing economies (IMF 2017; World Bank 2017a).

Fiscal space is a complex concept as evident from multiple definitions and measures used in the literature. Some authors define fiscal space simply as the budgetary room to create and allocate funding for a certain purpose, such as smoothing the business cycle, or undertaking growthenhancing investment projects, without threatening liquidity and sustainability of a sovereign's financial position (Heller 2005; Ley 2009). Perotti (2007) regards the notion of fiscal space as an alternative way of expressing a sovereign's intertemporal budget constraint. Others consider fiscal space as the difference between the current level of public debt and a country-specific debt limit (Ostry et al. 2010). ${ }^{2}$

Although there is no single definition, a core aspect of fiscal space is "the ability of a government to service its debt." Unless debt service capacity is maintained, a government cannot indefinitely finance its operations in a sound manner. Debt service capacity itself has multiple dimensions, including financing needs that are related to budget positions, access to liquid markets, resilience to valuation changes, and contingent liabilities.

Recent research presents databases that include select indicators of fiscal space, including those associated with the debt service capacity of sovereigns. ${ }^{3}$ Some authors focus on public debt series over a long period of time and/or for a large number of countries (Abbas et al. 2011; Jaimovich and Panizza 2010; Panizza 2008). Some others compile databases featuring the composition of government debt and provide data on contingent liabilities, revenues, and government investment and consumption for more limited country and time coverage. ${ }^{4}$ Others construct datasets that cover historical series of fiscal flow and stock indicators, but again with relatively limited country coverage (Mauro et al. 2015; Reinhart and Rogoff 2009).

Although the literature contains multiple measures of fiscal space, no database systematically brings together these measures for a large number of countries. Our paper aims to fill this gap. Specifically, our database expands on previous studies in two critical dimensions. First, it includes a

\footnotetext{
${ }^{1}$ Auerbach and Gorodnichenko (2013) and Huidrom et al. (2016) find that fiscal multipliers tend to be larger when fiscal space is wider.

${ }^{2}$ This is also the definition used by Ghosh et al. (2013) and Nerlich and Reuter (2015). Park (2012) defines fiscal space as revenue generating capacity which is the difference between current tax revenues and the maximum level that is estimated in a model. Aizenman and Jinjarak (2012) use de facto fiscal space, which is inversely related to tax-years needed for public debt to be repaid.

${ }^{3}$ We present a list of these studies in Supplementary Appendix Table A1.

${ }^{4}$ For studies on government debt, see Arslanalp and Tsuda (2014a, 2014b) and Cowan et al. (2006). For databases on government revenues, see Mansour (2014) and Prichard, Cobham, and Goodall (2014); for databases on government investment and consumption, see Ilzetzki, Mendoza, and Végh (2013). For fiscal consolidation data, see Guajardo, Leigh, and Pescatori (2014); for contingent liabilities, see Bova et al. (2016); for private debt data, see Bernardini and Forni (2017).
} 
wide range of indicators that go beyond simple measures of solvency. These consist of 28 indicators covering four broad aspects: government debt sustainability, balance sheet composition, external and private sector debt, and market perception of sovereign risk. These aspects materially affect the availability of fiscal space. For example, a higher share of short-term and foreign currency debt could raise rollover and exchange rate risks, respectively. A high share of nonresident holdings of government debt may imply liquidity risk as well as currency risk in the event of confidence losses among foreign investors. The maturity profile of debt is important since debt principal coming due often constitutes an important portion of an economy's upcoming financing needs, and a bunching of maturities can constrain fiscal space. Market participants' perceptions of sovereign risk reflect and, in turn, influence an economy's ability to tap markets and service its obligations.

The second innovative characteristic of our database is its wide country coverage. It contains data for up to 200 economies over the period 1990-2016. For most of the indicators, it relies on multiple cross-country sources. In Section 2, we describe indicators for government debt sustainability; balance sheet composition; external and private sector debt; and market perception. To facilitate cross-country comparisons, we look separately at advanced economies, and emerging market and developing economies (EMDEs) - the former contains 41 economies and the latter 159 economies. ${ }^{5}$

In Section 3, we first analyze the basic features of the fiscal space indicators. Simple correlations across indicators support their division into four groups, in that cross-indicator correlations are on average considerably larger within than across groups. We then describe the evolution of fiscal space since 2000. Our findings indicate widespread improvements in fiscal space before the global financial crisis. For example, most indicators improved in more than half of advanced economies, and virtually all improved in more than half of EMDEs.

However, mounting domestic contingent liabilities were a warning sign during this period. In advanced economies, following severe deteriorations during the crisis, many indicators of fiscal space have virtually returned to levels in the mid-2000s. In contrast, fiscal positions have worsened sharply in EMDEs since the crisis. Both the pre-crisis improvements and post-crisis deteriorations have been particularly marked among commodity-exporting EMDEs, in line with the pre-crisis run-up and post-crisis slide in commodity prices.

In Section 4, we provide two more applications to illustrate the potential use of our database. We first analyze the behavior of fiscal space during financial crises. Financial crises tend to coincide with a significant deterioration in multiple indicators of fiscal space, including fiscal debt sustainability and, to a lesser extent, sovereign credit ratings. Crises are often followed by reduced reliance on short-term borrowing. We then examine the behavior of fiscal space in energy-exporting EMDEs during oil price plunges. Collapses in oil prices also coincide with shrinking fiscal space. These episodes are typically followed by a rebound in indicators of fiscal space, often as a result of procyclical fiscal tightening and, in some episodes, a recovery in oil prices. In Section 5, we provide a short summary of our findings and discuss possible research directions.

\footnotetext{
${ }^{5}$ Countries are included in the database if data are available in any one of 28 indicators. Since country coverage does not always overlap between indicators, data are available up to 200 countries. While there are some countries for which only one indicator is available, the average number of available indicators per country is 19 .
} 


\section{Database}

\subsection{Data Sources}

In order to ensure quality and consistency, most series are obtained from databases maintained by international organizations in cooperation with national statistical agencies, using harmonized methodologies. Our data sources include four databases maintained by the World Bank: the World Development Indicators (WDI); International Debt Statistics (IDS); Quarterly External Debt Statistics (QEDS); and Quarterly Public Sector Debt (QPSD). We also employ four databases managed by the IMF - the World Economic Outlook (WEO); International Financial Statistics (IFS); World Revenue Longitudinal Dataset; and Government Financial Statistics. For some of the data series, information is gathered from the Joint External Debt Hub (JEDH) - a joint initiative by the World Bank, Bank for International Settlements (BIS), IMF, and Organisation for Economic Cooperation and Development (OECD) - and databases provided by the BIS, OECD, Bloomberg, J.P. Morgan, and Arslanalp and Tsuda (2014a, 2014b). We provide details of these sources in Table 1.

\subsection{Country and Time Coverage}

The database contains annual data for up to 200 economies from 1990 to 2016 in an unbalanced panel. It is nearly balanced since mid-2000 when data become available for a wider range of countries. Countries are classified into two groups (see Table 2 for details) - 41 advanced economies, and 159 EMDEs. The latter group is further classified into commodity exporters and importers, by applying the classification criteria used in World Bank (2017a). As a result, there are 91 commodityexporting EMDEs and 68 commodity-importing EMDEs. Out of 91 commodity exporters, 36 EMDEs are considered energy exporters.

\subsection{Indicators of Fiscal Space}

\subsubsection{Government Debt Sustainability}

Measures of debt sustainability and fiscal balance refer to the longer-run capacity of the government to finance its obligations. The set of indicators of government debt sustainability consists of twelve variables. The first three are available in, or can be computed from, the WEO dataset and QPSD database: general government gross debt and general government (primary and overall) net lending/borrowing in percent of GDP.

The longer-run viability of actual budgets may be gauged from the cyclically-adjusted balance, defined as the difference between cyclically-adjusted revenues and cyclically-adjusted expenditures. The cyclically-adjusted balance is defined as:

$$
c b=r e v \cdot(1+o g a p)^{-\left(\epsilon_{\text {rev }}-1\right)}-x p \cdot(1+o g a p)^{-\left(\epsilon_{x p}-1\right)}
$$

where $c b$ is the cyclically-adjusted balance expressed in percent of potential GDP; rev and $x p$ are revenues and expenditures in percent of GDP; and ogap is the difference between actual and potential output in percent of potential output (defined as the Hodrick-Prescott-filtered trend). We assume that an output gap elasticity of revenues, $\epsilon_{r e v}$, is one and an output gap elasticity of expenditures, $\epsilon_{x p}$, is close to zero, specifically 0.1 . When sub-components are aggregated, the 
elasticity of revenues to the output gap tends to be close to one, whereas most expenditures, except for benefits of a cyclical nature, are little correlated with output gaps (Fedelino, Ivanova, and Horton 2009). The cyclically-adjusted balance defined in equation (1) differs from a typical structural balance in its exclusion of one-off temporary expenditures (Bornhorst et al. 2011). Since our objective is to provide comparable definitions for as broad a set of countries as possible, these country-specific, one-off adjustments are not taken into consideration.

In many EMDEs, institutional weaknesses in the tax collection systems constrain the government's ability to service debt, even when debt ratios are moderate by the standards of advanced economies (Aizenman and Jinjarak 2012). Realized tax collection or the size of the tax base may provide a better gauge of a government's ability to service its debt than GDP. Hence, we calculate an additional pair of debt and fiscal balance indicators, as a percent of long-term average (since 1990) government tax revenues.

The sustainability of government debt depends, not only on debt and deficits, but also on growth and borrowing cost. Fiscal sustainability gaps are indicators for the pressures that could emerge from large fiscal deficits accumulating over time to unsustainable debt stocks, even when initial stocks are modest. These gap indicators provide a simple snapshot of the adjustments that may be needed to reach debt targets under different macroeconomic conditions (Buckle and Cruickshank 2013). Ley (2009) and Escolano (2010) outline the concept of sustainability that underlies the definition of this gap measure. The first of these indicators that we compute is the overall fiscal balance sustainability gap (fbsusgap):

$$
\text { fbsusgap }=b-\left(\frac{-\gamma}{1+\gamma}\right) d^{*}
$$

where $\gamma$ represents nominal output growth and $b$ the overall fiscal balance (in percent of GDP). The last term of equation (2) shows the overall fiscal balance that stabilizes the stock of debt (in percent of GDP) targeted at $d^{*}$. A positive gap indicates a fiscal balance that would diminish government debt, if sustained, over time, while a negative gap indicates a fiscal balance that would increase the stock of debt over time.

Nominal output growth $(\gamma)$ is calculated as a weighted average of percent changes in GDP expressed in local currency and in U.S. dollars at current exchange rates. The weights are defined as the long-term average (since 1990) share of general government debt denominated in foreign and local currency (as discussed in Section 2.3.2). For countries missing data on the currency composition of government debt, the median ratio of peer countries (advanced economies and EMDEs) is applied. ${ }^{6}$

The target debt ratio, $d^{*}$, is defined as being equal to the historical median value in an economy's peer group (advanced economies or EMDEs). Implicitly, compared with benchmarking against each economy's own historical median, this approach implies more favorable debt target in economies

\footnotetext{
${ }^{6}$ For Euro Area countries, two separate average shares are computed: before and after euro adoption. In EMDEs where the share of government debt in foreign currency is not available, the weight is computed by the share of government debt held by nonresidents as a proxy. The median share of foreign currency-denominated government debt for advanced economies is 1.5 percent (based on 17 countries). For Euro Area countries, the median share is 17 percent before euro adoption (6 countries) and 2.1 percent after euro adoption (12 countries). The median share for EMDEs is 42 percent (based on 45 countries).
} 
with debt below the peer-group median and less favorable debt target in economies with debt above the peer-group median. The target (and median) debt ratios for advanced economies and EMDEs are, respectively, 52.3 percent of GDP and 45.2 percent of GDP. While there is no mechanical rule to determine the threshold for "safe" levels of debt, the underlying assumption is that advanced economies tend to have a higher debt tolerance (BIS 2012).

We calculate sustainability indicators for primary balances as the primary balance sustainability gap, i.e., the difference between the primary balance and the debt-stabilizing primary balance (pbsusgap) with this equation:

$$
\text { pbsusgap }=p-\left(\frac{r-g}{1+g}\right) d^{*}=p-\left(\frac{i-\gamma}{1+\gamma}\right) d^{*}
$$

where $p$ is the primary balance (in percent of GDP), $i$ is the nominal long-term interest rate, $\gamma$ nominal GDP growth, $r$ the real interest rate (defined as the nominal interest rate deflated by the GDP deflator), $g$ real GDP growth, and $d^{*}$ the target debt ratio (in percent of GDP). Primary balance sustainability gaps are computed with the second half of equation (3), once again calculating $\gamma$ as a weighted average of percent changes in current local currency GDP and dollardenominated GDP. We calculate the sustainability gap indicators under five different assumptions for growth rates, interest rates, and target debt ratio as we discuss below. The derivation of the nominal long-term interest rate differs across countries because of data constraints (see Table A2 for details).

We derive five indicators using equation (3), applying country-specific and group-specific assumptions about input variables. The actual primary balance remains the same in all cases. We start out by calculating equation (3) using country-specific median values for GDP growth and interest rates over the full sample period. This is what we call the "primary balance sustainability gap under historical market conditions." Second, by using GDP growth and interest rates at their current levels in equation (3), we obtain the "primary balance sustainability gap under current market conditions."

The third indicator within this set is the "primary balance sustainability gap under stressed conditions." For this indicator, $\gamma$ is defined as the country-specific sample median of nominal GDP growth minus one country-specific standard deviation of growth. The nominal interest rate $(i)$ is calculated as the country-specific median plus one country-specific standard deviation. Hence, this variable shows whether the primary balance would be debt-stabilizing if conditions were to worsen sharply (but within reasonable bounds).

The fourth indicator is a "primary balance sustainability gap under benign conditions" based on country-specific minimum interest rates and maximum growth rates. To avoid identifying extremely low interest and high growth rates, we first compute 10-year moving averages of interest and growth rates and define minimum and maximum values from these averages.

These four indicators are based on the historical country-group median debt stocks as the target debt ratio, as in the overall balance sustainability gap. Finally, we calculate an additional primary balance sustainability gap at historical conditions, by using country-specific median values for interest rates, GDP growth, and the target debt level. 


\subsubsection{Balance Sheet Composition}

Balance sheet composition may affect exposures to the risks of a sudden change in financial market conditions. The set of indicators focuses on the structure of sovereign balance sheets, including sources of funding, currency structure and maturity profile. These indicators gauge the risk that sharp swings in interest rates or exchange rates, or a shut-off of capital inflows, might undermine liquidity or solvency. For example, concentration of short-term and foreign currency-denominated debt makes a government's balance sheet vulnerable to rollover and exchange rate risks, respectively, and a high share of nonresident holdings of government debt would imply liquidity risk in the event of confidence losses among foreign investors. ${ }^{7}$

The variables included in this category are: general government debt in foreign currency in percent of total general government debt; debt securities held by nonresidents in percent of total debt securities; general government debt held by nonresidents in percent of total general government debt; concessional external debt stocks in percent of general government gross debt; sovereign debt average maturity; and central government debt maturing in 12 months or less in percent of GDP.

These six variables are constructed with information collected from multiple data sources. The share of foreign currency debt over total government debt is computed from the OECD and QPSD databases. The value of debt securities held by nonresidents is reported in JEDH, which is derived from the IMF's bilateral portfolio investment database. The total amount of outstanding debt securities is taken from the debt securities statistics of the BIS. ${ }^{8}$ The share of government debt held by nonresidents is obtained from the QPSD database. For countries not covered by the preceding databases, the share is extracted from Arslanalp and Tsuda (2014a, 2014b), who maintain datasets documenting the sovereign investor base for advanced economies and emerging markets. Their datasets are also used to extend the main series if there are missing data points. Data on concessional finance are available from the WDI, and expressed as a ratio to general government gross debt (from the WEO). This is a useful measure of fiscal space, especially for low-income countries.

The average maturity of sovereign debt is derived from two sources. Within the emergingmarket debt universe, sovereign bonds denominated in foreign currency constitute a significant share in many countries, and provide a vehicle for these economies to access the world's largest and most liquid funding pools. The average maturity of sovereign debt for EMDEs and some advanced economies is proxied by the annual average life (average time of principal repayment) of the national sub-indices of the J.P. Morgan EMBI Global index. ${ }^{9}$ For other advanced economies, the maturity

\footnotetext{
${ }^{7}$ Similar variables are used by previous studies. The composition of advanced economies' sovereign bond investor pool is analyzed in IMF (2012), noting the risks of sudden changes in investor sentiment to exchange rate and interest rate stability, and, consequently, the possible emergence of funding gaps. Martínez Carrera and Vergara (2012) analyze the magnitude of the fiscal adjustment needed to restore fiscal sustainability after a devaluation. Currency composition and maturity structure variables are commonly used in the literature on early warning exercises of fiscal problems (Baldacci et al. 2011).

${ }^{8}$ The series includes debt securities in the private sector but, in view of the large share of general government in portfolio debt securities liabilities, this variable can also show the balance sheet vulnerability of sovereigns. The median share of general government in the liability position of portfolio debt securities (classified as in the Sixth edition of Balance of Payments Manual) is 72 percent, based on the data for 100 countries over 1990-2015. In the debt securities statistics of the BIS, data on currency decomposition of international debt securities issued by general government are also available.

${ }^{9}$ These indices are made up of sovereign and quasi-sovereign instruments denominated in U.S. dollars. Bonds also have to comply with a strict set of rules in order to be included: they must have legal jurisdiction in a G7 economy, a minimum issue size of $\$ 500$ million, a maturity of at least 2.5 years at the time of entry (and 1 year overall minimum) and they must be sufficiently liquid for prices to be available daily (Kim 2014).
} 
profile of government debt is obtained from the FTSE via Bloomberg. Central government debt maturing within 12 months is sourced from Bloomberg and calculated in percent of GDP. Debt principal coming due usually constitutes the largest portion of an economy's upcoming financing needs, and may impose a constraint on a government's ability to raise new money to finance the current budget deficit.

\subsubsection{External and Private Sector Debt}

The group of external and private sector debt indicators includes measures of the size and composition of a country's total external debt, their relation to foreign exchange reserves and the liabilities of the private sector. The variables in this category are: total external debt stocks in percent of GDP; external debt in foreign currency in percent of total external debt; private external debt stocks in percent of GDP; domestic credit to the private sector in percent of GDP; short-term external debt stocks in percent of total external debt stocks; short-term external debt stocks in percent of total reserves; total external debt stocks in percent of total reserves; and total external debt stocks in percent of reserves excluding gold.

Private sector debt (domestic and external) has the potential to impact fiscal sustainability if explicit or implicit bailout guarantees create contingent liabilities, which would oblige governments to assume private liabilities in the event of the failure of the borrower (Cebotari 2008). The costs associated with such interventions would rise with the overall size of private sector obligations and maturity or currency mismatches. For example, one channel through which private obligations generate fiscal costs is in the resolution of failing banks. This may include explicit guarantees (e.g., through deposit insurance), nationalization, recapitalizations, and the setup of asset management companies. External and (private) domestic vulnerabilities are also closely linked: when private firms are hit by a sharp depreciation shock or an asset price collapse, currency mismatches and excessive borrowing can feed into their solvency problems (Hausmann and Panizza 2011).

The most encompassing variable within this group is the share of total external debt over GDP. The data on external debt are available in the QEDS and IDS. We use the QEDS as the primary source of data and then use the IDS for countries or years not covered by the QEDS. The share of external debt in foreign currency is computed from QEDS. Likewise, the share of short-term debt in total external debt is based on the QEDS and IDS.

The share of private external debt over GDP is calculated as the difference between a country's gross external debt position and public sector external debt position in QEDS. However, the data on public sector external debt are not always available in the QEDS dataset. For those countries that do not have data for public external debt, the sum of general government and central bank external debt stocks are used, though this ignores debt of public banks and other public corporations. When the QEDS data are unavailable, the series of long-term private sector external debt stocks from IDS are reported (as IDS does not report the short-term private external debt). ${ }^{10}$

The share of domestic credit to the private sector in percent of GDP is available through the WDI and IFS, and in BIS's dataset of credit to the non-financial sector. It refers to the sum of commercial banks' and other financial corporations' claims on the non-financial private sector (and, for some countries, on public enterprises too). Rising levels of private debt may reflect financial

\footnotetext{
${ }^{10}$ Because of different definitions of private external debt between QEDS (which includes both short and long-term private debt) and IDS (which includes only long-term private debt), cross-country comparisons of these series require caution. The database explains the sources of external debt data in each country.
} 
deepening or unsustainable credit booms; in practice and in real time, these two causes of rising debt are often impossible to disentangle. Regardless of the underlying causes for high or rising private debt, the full amount of private debt risks, under stress conditions, to impose fiscal cost.

The last three variables in this group capture aspects of a country's reserve adequacy, calculated as the ratio of short-term external debt over reserves, the ratio of total external debt over reserves, and the ratio of total external debt over foreign exchange reserves excluding gold.

\subsubsection{Market Perception}

Our dataset includes market perception indicators on a country's ability to roll over debt, or to issue new debt, and on its market cost of borrowing. Market participants' perceptions of sovereign risk reflect and, in turn, shape an economy's ability to tap markets and service its obligations. Market perception indicators can serve as high-frequency proxies for fiscal sustainability. They are often available when timely information on macroeconomic fundamentals is not. The variables included are the 5-year sovereign CDS spread and foreign currency long-term debt ratings by major international rating agencies.

The first indicator, the sovereign CDS spread, is taken from Bloomberg and J.P. Morgan and monitors investor sentiment about sovereign credit risk. ${ }^{11}$ Our second variable is an annual average of foreign currency long-term sovereign debt ratings by Moody's, Standard \& Poor's, and Fitch Ratings, which are available in Bloomberg on a daily basis. As rating agencies clearly state that rating stability is among their objectives, sovereign ratings provide an alternative perspective of investor sentiment to high-frequency market indicators. Credit rating agencies base their sovereign ratings on a combination of economic, institutional, and political factors in order to assess an issuer's creditworthiness based not only on its ability, but also on its willingness to pay. Sovereign ratings are ultimately determined by a wider range of indicators than those included in the database, but there is significant overlap in evaluation of risk factors affecting public finances. Ratings of each agency are converted to a numerical scale to construct an index. We assign 1 to the worst rating and 21 to the best one and then take a simple average of three ratings.

\section{Main Features of Fiscal Space}

This section first briefly presents the main features of the indicators of fiscal space. We then analyze the evolution of fiscal space over time.

\subsection{Comovement, Volatility and Size}

Comovement. Our allocation of fiscal space indicators into four distinct groups is supported by cross-indicator correlations. Within each group, the correlations across the various individual indicators are considerably larger on average, and a larger number of them are significant, than across groups. For example, the 66 correlations between the twelve indicators within the debt sustainability grouping average 0.58 and all the individual correlations are statistically significantly different from zero (at least at the 5 percent level) (Tables 3 and A3).

\footnotetext{
${ }^{11} \mathrm{CDS}$ spreads tend to be cointegrated with sovereign bond yields. Both are affected by factors such as counterparty and liquidity risk. The causal relationship between the two depends on specific market and macroeconomic conditions (IMF 2012).
} 
In contrast, only a half ( 36 of 72 ) of the correlations between the indicators in the debt sustainability group and the balance sheet group are statistically significant; on average, the correlation across these two groups is near-zero (0.09). Similarly, the cross-indicator correlations within the group of balance sheet indicators average 0.27 and those within the group of external and private sector debt average 0.42 . Cross-indicator correlations for advanced economies, as well as for EMDEs, point to the distinctive information presented by these four separate groups of indicators.

Volatility. The volatility of government debt sustainability indicators has declined over time but that of external and private sector debt has increased. The volatility of debt and fiscal balance indicators relative to tax revenues tends to be larger than that of those relative to GDP, indicating that the former has a wider range and contains some large outliers. In most cases, variation in the volatility of fiscal space indicators is larger when indicators are compared across countries than compared over time within a country (Table A4).

Size. On average over the full sample, as well as separately in the 1990s and 2000s, fiscal space in advanced economies has been considerably narrower than in EMDEs in most dimensions, with two critical exceptions. Government debt sustainability measures in advanced economies were weaker, and private as well as government balance sheet exposures to various risks larger (Tables 4-6). For example, since 2008, debt levels have been higher in advanced economies (66.5 percent of GDP) than in EMDEs (45.6 percent of GDP), and sovereign debt has been of shorter maturity in advanced economies.

However, in two critical dimensions, advanced economies have greater fiscal space than EMDEs. First, advanced economies have persistently had considerably lower debt-to-revenue ratios, possibly reflecting greater revenue-raising capacity and stronger institutions. Second, advanced economies owe a considerably lower share of foreign currency-denominated debt, reflecting reserve currency status and more credible monetary policy frameworks. This may account for the more favorable market perception indicators for advanced economies than for EMDEs (Dell'Erba, Hausman, and Panizza 2013).

\subsection{Evolution of Fiscal Space}

After improving during 2000-07 from the 1990s, fiscal space has shrunk around the world since the global financial crisis (Tables 4-6 and A5). The improving trend prior to the crisis was widely shared: virtually all indicators of fiscal space expanded in more than half of EMDEs; and most indicators improved in more than half of advanced economies (Tables A6 and A7). After the crisis, however, government debt as well as fiscal sustainability gaps have deteriorated in at least threequarters of countries in the world. External and private debt stocks have also increased in more than half of all countries and perceptions of market participants have worsened.

The post-crisis deterioration in fiscal space was more strongly synchronized than the pre-crisis improvement. From 2007, almost half of the indicators deteriorated in at least two-thirds of the countries in the sample. As a result, fiscal space in the majority of EMDEs ended 2016 narrower in most dimensions than in 2000 or 1995 . This was partly mitigated by record low interest rates and high reserve buffers. The broad patterns were particularly pronounced in commodity-exporting economies and in regions with predominantly commodity-exporting EMDEs.

Pre-crisis improvements in fiscal space. In EMDEs, and to a considerably lesser extent in advanced economies, government debt sustainability improved significantly as rapid growth reduced 
deficits, and helped reduce debt stocks prior to the global financial crisis (Figure 1). Fiscal deficits during the global slowdown of 2001 ( 0.7 percent of GDP in advanced economies, 2.8 percent of GDP in EMDEs) turned into surpluses by 2007 (1.8 percent of GDP in advanced economies, 1.4 percent of GDP in EMDEs). In low-income developing economies, relief initiatives such as the Heavily Indebted Poor Countries initiative and the Multilateral Debt Relief Initiative helped reduce debt burdens. These improvements helped reduce general government gross debt by 33 percentage points of GDP over 2001-07 in EMDEs, to 47 percent of GDP. Government debt in advanced economies was also stabilized at about 47 percent of GDP. By 2007, fiscal positions in 90 percent of countries in the world were sustainable under current as well as, to a lesser degree (75 percent of countries), historical conditions.

In advanced economies, government balance sheet indicators moved in different directions. While the share of government debt held by nonresidents increased, the foreign currency share declined and the maturity of debt became longer (Figure 2 and Table A6). External debt increased by 90 percentage points to exceed 320 percent of GDP in 2007 from the early 2000s. Domestic currency liabilities dominated this growth, as the share of foreign currency-denominated external debt declined by around 10 percentage points to 53 percent. In addition, mounting domestic contingent liabilities were a warning sign of risks ahead, evidenced by the rise in private sector credit to 110 percent of GDP. In more than three-quarters of advanced economies, private sector credit rose in tandem with external debt (Table A6).

In EMDEs, external debt declined. By 2007, the external debt-to-GDP ratio was below the levels of the early 2000s in three-quarters of EMDEs - but external debt had become increasingly short-term. Sovereign spreads in EMDEs became markedly smaller between 2000 and 2007 (Figure 3). In more than two-thirds of EMDEs, declining external exposures were accompanied by rising domestic private sector credit (Table A7).

Post-crisis deterioration in fiscal space. Since the crisis, fiscal positions have deteriorated sharply in EMDEs as activity has slowed. In contrast, in advanced economies, following severe deteriorations during the 2009 global recession, most indicators of government debt sustainability have virtually returned to levels in the mid-2000s.

In advanced economies, the fiscal primary balance has turned into a surplus of 0.6 percent of GDP in 2016 from a deficit of near 4 percent of GDP in 2009. Sustainability gaps have closed such that, on average and especially under current or benign conditions, debt stocks would stabilize or even slowly decline (Botev, Fournier, and Mourougane 2016). Government debt, which grew by more than 15 percentage points of GDP between 2007 and 2010, has stabilized around at elevated 70 percent of GDP (Dobbs et al. 2015). As a result of narrower fiscal deficits, fiscal positions now appear to be sustainable in more than two-thirds of advanced economies at current financing conditions, and in more than half of advanced economies under (less benign) historical financing conditions. Despite these improvements since the crisis, advanced economy credit ratings remain lower than before the crisis.

In EMDEs, in contrast, debt sustainability indicators have steadily deteriorated since 2011 (Figure 1). Partly as a result of steep revenue losses in commodity-exporting EMDEs, sustainability gaps and fiscal deficits have, on average, widened to 3-5 percent of GDP in 2016. Sustainability gaps in EMDEs have worsened since the pre-crisis level, and, in around three-quarters of EMDEs, fiscal positions are clearly debt-increasing under current conditions (Figure 4). Government debt 
has risen to 53 percent of GDP, on average, in 2016, exceeds 2000 levels in more than one third of EMDEs and is increasingly held by non-residents (Table A7).

External debt and private sector credit have risen from 2007 levels in at least three-quarters of EMDEs. A rapid increase in private sector credit, especially for corporates, since the global financial crisis has been accompanied by weaker solvency and profitability positions (Alfaro et al. 2017). Reflecting deteriorating debt sustainability, balance sheet risks and contingent liabilities, credit ratings of EMDEs have (marginally) worsened on average and, in more than half of EMDEs, have weakened since 2007. As a result of the post-crisis deterioration, most indicators of fiscal space were narrower in 2016 than in the late 1990s in the majority of EMDEs. The exception is external vulnerabilities, which have been mitigated by a reserve buildup.

Divergence between commodity exporters and importers. The evolution of fiscal space has diverged sharply between commodity exporters and importers (Figure 5). Both the pre-crisis improvement and the post-crisis deterioration have been particularly pronounced among commodity-exporting EMDEs, in line with the cycle in commodity prices (World Bank 2017b).

By 2007, sustainability gaps in excess of 5 percent of GDP set government debt on a declining path in 80 percent of commodity-exporting EMDEs. A sharp deterioration during the global recession of 2009 was reversed within a year. However, since the onset of the commodity price slide in 2011, fiscal sustainability gaps have steadily deteriorated, and since 2014 they have been materially below those of commodity importers. This has also been reflected in a sharp deterioration in credit ratings.

In commodity-importing EMDEs, the post-crisis deterioration in fiscal space has been more gradual than in commodity-exporting EMDEs. On the eve of the global financial crisis, in 2007, public debt stocks were much higher than those of commodity exporters. Post-crisis, sustainability gaps have reverted to debt-increasing positions. Accordingly, this has contributed a decline in credit ratings, although it has been more gradual than in commodity exporters. Under current conditions, sustainability gaps were below zero (i.e., debt-increasing) in three-fifths of commodity importers in 2016.

\section{How Does Fiscal Space Evolve During Periods of Financial Stress?}

The global financial crisis of 2008-09 is an exceptional episode, among many periods of financial stress. Past financial stress episodes have often been associated with financial crises, including collapses of currencies, acute fiscal challenges, or with collapses of commodity prices for those relying heavily on commodity revenues. In this section, we first analyze the behavior of fiscal space during different types of financial crises. ${ }^{12}$ We then briefly examine the evolution of fiscal space in energy-exporting EMDEs during oil price plunges.

\subsection{Fiscal Space During Financial Crises}

We group financial crises into currency crises, banking crises and government debt distress episodes following Gourinchas and Obstfeld (2012), and Laeven and Valencia (2013). Our sample of crises

\footnotetext{
${ }^{12}$ An extensive literature discusses the impact of crises on fiscal positions and the linkages between sovereign and banking sector issues during financial crises (Fratzscher, Mehl, and Vansteenkiste 2011; Reinhart and Rogoff 2009; Tagkalakis 2013).
} 
covers 33 financial crisis episodes for advanced economies, and 160 crises for EMDEs (Table A8). We consider the behavior of a wide range of fiscal space measures, including government debt sustainability, private and external debt, and market perception indicators. Fiscal debt sustainability in advanced economies deteriorated sharply during and in the immediate aftermath of crises, especially after banking crises (Figure 6 and Table A9).

Debt sustainability. The deterioration after banking crises to some extent reflects the cost of government bail-outs (Tagkalakis 2013). The average level of government debt in advanced economies was 49 percent of GDP just before a banking crisis and jumped to 66 percent of GDP afterwards. Similarly, in EMDEs, government debt surged, on average, from 37 percent of GDP to 53 percent of GDP. With rising debt, sharply widening primary deficits and slowing growth, fiscal sustainability deteriorated significantly during crises. For example, the primary balance sustainability gap under current conditions in advanced economies was 3 percent of GDP before a banking crisis but worsened to -8 percent of GDP, on average, in the two years after the crisis. In EMDEs, positive sustainability gaps of 2.3 percent of GDP, which had put debt on a declining path, before a banking crisis turned into negative (debt-increasing) gaps of -2.7 percent of GDP, on average, in the two years after the crisis. Indeed, fiscal positions sharply deteriorated in a year after a banking crisis with sustainability gaps of -10 percent of GDP but became debt-reducing in two years (3 percent of GDP).

Balance sheet composition. Crises were often followed by reduced reliance on short-term external borrowing, in both advanced economies and EMDEs. The share of short-term external debt fell, on average, by 2-3 percentage points in the wake of banking and currency crises and debt distress in EMDEs. After a debt distress episode in EMDEs, sovereign debt maturities shortened significantly more than after other types of crises.

Private and external debt. During crises deleveraging that reduced private and external debt proceeded. Crises were associated with significant declines in private sector credit. Prior to crises, the ratio of private sector debt-to-GDP grew on average by around 2.5 percentage points. In the two years following crises, private sector credit declined on average by 2 percentage points of GDP in EMDEs, and by 2.7 percentage points of GDP in advanced economies (and in both country groups, changes are statistically significant after banking crises). Similarly, external debt also declined, or the pace of debt accumulation decelerated. In EMDEs, external debt contracted sharply after currency crises and debt distress by 3.3 percentage points of GDP, on average. In advanced economies, in contrast, external debt continued to grow after banking crises but at a slower rate.

Market perception. Deteriorating sovereign debt sustainability was accompanied by statistically significant downgrades in credit ratings. In advanced economies, after banking and currency crises, credit ratings declined by two notches. In EMDEs, any type of financial crisis is, on average, associated with a decline in credit ratings by more than two notches.

In advanced economies, government debt has recently been about 71 percent of GDP, a historic high, and well above the roughly 50 percent of GDP in the year before past banking and currency crises. In contrast, in EMDEs, the recent level of government debt (53 percent of GDP) has been lower than on the eve of historical debt distress episodes (73 percent of GDP) or currency crises (69 percent of GDP), although above that during banking crises (37 percent of GDP). These developments have been reflected in weaker sovereign credit ratings in advanced economies, and stronger ratings than before past currency crises and debt distress in EMDEs (Figure 6). Almost 
all indicators of fiscal space currently compare unfavorably, especially in EMDEs, with the previous periods leading up to crises (Table A10). In particular, private debt is more elevated now than on the eve of the observed crises in EMDEs. Private sector credit is higher now than before previous crises. In advanced economies, private sector credit is as high as those seen before earlier crisis episodes. The share of short-term external debt is somewhat lower in advanced economies and almost the same in EMDEs, compared to those in past crises.

\subsection{Fiscal Space During Oil Price Plunges}

Fiscal space in energy-exporting EMDEs is closely related to the behavior of oil prices, as these economies tend to heavily rely on fiscal revenues from the energy sector. In some of energyexporting EMDEs, hydrocarbon revenues account for more than half of these revenues. Collapses in oil and other energy prices can therefore force them into sharp fiscal adjustment. We focus on 36 energy-exporting EMDEs and study how fiscal space evolves during episodes of major oil price plunges - 1991, 1998, 2001, 2008 and 2014 (Table 2). These major collapses of global oil prices are identified as nonconsecutive decline episodes in prices where an average of Brent, Dubai, and West Texas Intermediate oil prices dropped by more than 30 percent over a six-month period.

Fiscal space deteriorated sharply during past oil price plunges but rebounded quickly as a result of procyclical fiscal tightening and, in some cases, a recovery in oil prices (Figure 7; Danforth, Medas, and Salins 2016). Prior to past oil price plunges, energy-exporting EMDEs had highly favorable debt sustainability indicators: primary surpluses were accompanied by positive sustainability gaps and government debt was on a declining path. Fiscal positions significantly worsened during and in the immediate aftermath of oil price collapses as primary surpluses turned into deficits and government debt was set on a firmly rising trajectory (Table A11).

Within three years after the plunges, however, sustainability gaps returned to being debtreducing and were restored close to the pre-plunge levels. Sovereign debt maturities shortened only marginally. Despite the deterioration in fiscal positions, the adverse impact on sovereign ratings was small. External debt rose during oil price plunges but stabilized quickly. The rebound in indicators of fiscal space was often as a result of procyclical fiscal tightening and, in some episodes, a recovery in oil prices. Compared to these earlier oil price plunges, energy-exporting EMDEs entered the most recent plunge of 2014 with lower government debt but underwent a sharper deterioration in fiscal positions than in previous plunges.

\section{Conclusion}

We present a new, comprehensive, cross-country database of fiscal space for up to 200 countries over the period 1990-2016. Drawing on a wide range of sources, we bring together 28 indicators of fiscal space that are grouped into four broad categories: government debt sustainability, balance sheet composition, external and private sector debt, and market perception of sovereign risk. Each of these categories covers a different dimension of fiscal space.

After describing the data sources and methodology employed to construct our indicators, we analyze the basic features of fiscal space indicators. Simple correlations across indicators lend support to our four-part categorization: the cross-indicator correlations are considerably larger within groups than across groups. We then analyze the evolution of fiscal space since 2000. There were significant improvements during the 2000s, but this was followed by a shrinkage of fiscal space 
around the world since the global financial crisis. Specifically, fiscal space has shrunk in many emerging market and developing economies since the global financial crisis, although it remains larger than during the late 1990s. In contrast, in advanced economies, most indicators of government debt sustainability have virtually returned to levels in the mid-2000s. We also examine how fiscal space evolves during financial crises and oil price plunges. Financial crises coincide with a deterioration in multiple indicators of fiscal space but are often followed by reduced short-term borrowing. Although fiscal space worsens during oil price plunges, indicators of government debt sustainability typically rebound close to pre-plunge levels within three years, partly as a result of procyclical fiscal tightening and recovering oil prices.

Fiscal space is a multi-dimensional concept at the heart of often contentious policy debates. Our cross-country database provides a source to analyze a broad set of fiscal space measures for informed debate about policy options. Our findings also suggest promising avenues for future research. For example, it would be useful to analyze which dimensions of fiscal space are most relevant in assessing the effectiveness of fiscal policy. Another interesting question is on the relative importance of determinants of market perception indicators in different country groups. Specifically, it would be useful to undertake an empirical study of the role of revenue raising capacity, institutional quality, and other possible factors in explaining differences in market perception indicators of different country groups. 


\section{References}

[1] Abbas, S. M. A., N. Belhocine, A. El-Ganainy, and M. Horton. 2011. "Historical Patterns and Dynamics of Public Debt-Evidence from a New Database." IMF Economic Review 59 (4): $717-742$.

[2] Abbas, S. M. A., and J. E. Christensen. 2010. "The Role of Domestic Debt Markets in Economic Growth: An Empirical Investigation for Low-Income Countries and Emerging Markets." IMF Staff Papers 57 (1): 209-255.

[3] Aizenman, J., and Y. Jinjarak. 2012. "The Fiscal Stimulus of 2009-2010: Trade Openness, Fiscal Space, and Exchange Rate Adjustment." In NBER International Seminar on Macroeconomics 2011, edited by J. Frankel and C. Pissarides, 301-342. Chicago: University of Chicago Press.

[4] Alfaro, L., G. Asis, A. Chari, and U. Panizza. 2017. "Lessons Unlearned? Corporate Debt in Emerging Markets." NBER Working Paper 23407, National Bureau of Economic Research, Cambrdige.

[5] Arslanalp, S., and T. Tsuda. 2014a. "Tracking Global Demand for Advanced Economy Sovereign Debt." IMF Economic Review 62 (3): 430-464.

[6] Arslanalp, S., and T. Tsuda. 2014b. "Tracking Global Demand for Emerging Market Sovereign Debt." IMF Working Paper 14/39, International Monetary Fund, Washington, DC.

[7] Auerbach, A. J., and Y. Gorodnichenko. 2013. "Fiscal Multipliers in Recession and Expansion." In Fiscal Policy after the Financial Crisis, edited by A. Alesina and F. Giavazzi, 63-98. Chicago: University of Chicago Press.

[8] Baldacci, E., I. Petrova, N. Belhocine, G. Dobrescu, and S. Mazraani. 2011. "Assessing Fiscal Stress." IMF Working Paper 11/100, International Monetary Fund, Washington, DC.

[9] Bernardini, M., and L. Forni. 2017. "Private and Public Debt: Are Emerging Markets at Risk?" IMF Working Paper 17/61, International Monetary Fund, Washington, DC.

[10] BIS (Bank for International Settlements). 2012. "Fiscal Policy, Public Debt and Monetary Policy in Emerging Market Economies." BIS Paper 67, Bank for International Settlements, Basel.

[11] Bornhorst, F., G. Dobrescu, A. Fedelino, J. Gottschalk, and T. Nakata. 2011. "When and How to Adjust Beyond the Business Cycle? A Guide to Structural Fiscal Balances." IMF Technical Notes and Manuals 11/02, International Monetary Fund, Washington, DC.

[12] Botev, J., J.-M. Fournier, and A. Mourougane. 2016. "A Re-Assessment of Fiscal Space in OECD Countries." OECD Economics Department Working Papers 1352, Organisation for Economic Co-operation and Development, Paris.

[13] Bova, E., M. Ruiz-Arranz, F. Toscani, and H. E. Ture. 2016. "The Fiscal Costs of Contingent Liabilities: A New Dataset." IMF Working Paper 16/14, International Monetary Fund, Washington, DC.

[14] Bua, G., J. Pradelli, and A. F. Presbitero. 2014. "Domestic Public Debt in Low-Income Countries: Trends and Structure." Review of Development Finance 4 (1): 1-19. 
[15] Buckle, R. A., and A. A. Cruickshank. 2013. "The Requirements for Long-Run Fiscal Sustainability." New Zealand Treasury Working Paper 13/20, New Zealand Treasury, Wellington.

[16] Cebotari, A. 2008. "Contingent Liabilities: Issues and Practice." IMF Working Paper 08/245, International Monetary Fund, Washington, DC.

[17] Cowan, K., E. Levy-Yeyati, U. Panizza, and F. Sturzenegger. 2006. "Sovereign Debt in the Americas: New Data and Stylized Facts." IADB Working Paper 577, Inter-American Development Bank, Washington, DC.

[18] Danforth, J., P. Medas, and V. Salins. 2016. "Fiscal Policy: How to Adjust to a Large Fall in Commodity Prices." IMF How to Notes 1, International Monetary Fund, Washington, DC.

[19] Dell'Erba, S., R. Hausmann, and, U. Panizza. 2013. "Debt Levels, Debt Composition, and Sovereign Spreads in Emerging and Advanced Economies." Oxford Review of Economic Policy 29 (3): $518-547$.

[20] Dobbs, R., S. Lund, J. Woetzel, and M. Mutafchieva. 2015. "Debt and (Not Much) Deleveraging." McKinsey Global Institute report, February, McKinsey \& Company, New York.

[21] Escolano, J. 2010. "A Practical Guide to Public Debt Dynamics, Fiscal Sustainability, and Cyclical Adjustment of Budgetary Aggregates." IMF Technical Notes and Manuals 10/02, International Monetary Fund, Washington, DC.

[22] Fedelino, A., A. Ivanova, and M. Horton. 2009. "Computing Cyclically Adjusted Balances and Automatic Stabilizers." IMF Technical Notes and Manuals 09/05, International Monetary Fund, Washington, DC.

[23] Fratzscher, M., A. Mehl, and I. Vansteenkiste. 2011. "130 Years of Fiscal Vulnerabilities and Currency Crashes in Advanced Economies." IMF Economic Review 59 (4): 683-716.

[24] Ghosh, A. R., J. I. Kim, E. G. Mendoza, J. D. Ostry, and M. S. Qureshi. 2013. "Fiscal Fatigue, Fiscal Space and Debt Sustainability in Advanced Economies." The Economic Journal 123 (February): F4-F30.

[25] Gourinchas, P.-O., and M. Obstfeld. 2012. "Stories of the Twentieth Century for the TwentyFirst." American Economic Journal: Macroeconomics 4 (1): 226-265.

[26] Guajardo, J., D. Leigh, and A. Pescatori. 2014. "Expansionary Austerity? International Evidence." Journal of the European Economic Association 12 (4): 949-968.

[27] Hausmann, R., and U. Panizza. 2011. "Redemption or Abstinence? Original Sin, Currency Mismatches and Counter Cyclical Policies in the New Millennium." Journal of Globalization and Development 2 (1): Article 4.

[28] Heller, P. S. 2005. "Understanding Fiscal Space." IMF Policy Discussion Paper 05/4, International Monetary Fund, Washington, DC.

[29] Huidrom, R., M. A. Kose, J. J. Lim, and F. L. Ohnsorge. 2016. "Do Fiscal Multipliers Depend on Fiscal Positions?" World Bank Policy Research Working Paper 7724, World Bank, Washington, DC.

[30] Ilzetzki, E., E. G. Mendoza, and C. A. Végh. 2013. "How Big (Small?) Are Fiscal Multipliers?" Journal of Monetary Economics 60 (2): 239-254. 
[31] IMF (International Monetary Fund). 2012. Global Financial Stability Report: The Quest for Lasting Stability. April. Washington, DC: International Monetary Fund.

[32] IMF. 2017. "Global Prospects and Policy Challenges." Staff note prepared for the G-20 Finance Ministers and Central Bank Governors' Meetings in Baden-Baden, Germany, March 17-18. International Monetary Fund, Washington, DC.

[33] Jaimovich, D., and U. Panizza. 2010. "Public Debt around the World: A New Data Set of Central Government Debt." Applied Economics Letters 17 (1): 19-24.

[34] Jeanne, O., and A. Guscina. 2006. "Government Debt in Emerging Market Countries: A New Data Set." IMF Working Paper 06/98, International Monetary Fund, Washington, DC.

[35] Kim, G. 2014. "EMBI Global and EMBI Global Diversified: Rules and Methodology." Global Index Research, June 30, J.P. Morgan Securities LLC, New York.

[36] Laeven, L., and F. Valencia. 2013. "Systemic Banking Crises Database." IMF Economic Review $61(2): 225-270$.

[37] Ley, E. 2009. "Fiscal Policy for Growth." PREM Note 131, World Bank, Washington, DC.

[38] Mansour, M. 2014. "A Tax Revenue Dataset for Sub-Saharan Africa: 1980-2010." FERDI Working Paper I19, Foundation for International Development Study and Research, ClermontFerrand.

[39] Martínez Carrera, C., and R. Vergara. 2012. "Fiscal Sustainability: The Impact of Real Exchange Rate Shocks on Debt Valuation, Interest Rates and GDP Growth." World Development 40 (9): 1762-1783.

[40] Mauro, P., R. Romeu, A. Binder, and A. Zaman. 2015. "A Modern History of Fiscal Prudence and Profligacy." Journal of Monetary Economics 76 (November): 55-70.

[41] Nerlich, C., and W. H. Reuter. 2015. "Fiscal Rules, Fiscal Space and Procyclical Fiscal Policy." ECB Working Paper 1872, European Central Bank, Frankfurt am Main.

[42] Ostry, J. D., A. R. Ghosh, J. I. Kim, and M. S. Qureshi. 2010. "Fiscal Space." IMF Staff Position Note 10/11, International Monetary Fund, Washington, DC.

[43] Panizza, U. 2008. "Domestic and External Public Debt in Developing Countries." UNCTAD Discussion Paper 188, United Nations Conference on Trade and Development, Geneva.

[44] Park, S. G. 2012. "Quantifying Impact of Aging Population on Fiscal Space." IMF Working Paper 12/164, International Monetary Fund, Washington, DC.

[45] Perotti, R. 2007. "Fiscal Policy in Developing Countries: A Framework and Some Questions." World Bank Policy Research Working Paper 4365, World Bank, Washington, DC.

[46] Prichard, W., A. Cobham, and A. Goodall. 2014. "The ICTD Government Revenue Dataset." ICTD Working Paper 19, International Centre for Tax and Development, Brighton.

[47] Reinhart, C. M., and K. S. Rogoff. 2009. This Time is Different: Eight Centuries of Financial Folly. Princeton: Princeton University Press. 
[48] Reinhart, C. M., and K. S. Rogoff. 2011. "The Forgotten History of Domestic Debt." The Economic Journal 121 (552): 319-350.

[49] Tagkalakis, A. 2013. "The Effects of Financial Crisis on Fiscal Positions." European Journal of Political Economy 29 (March): 197-213.

[50] World Bank. 2017a. Global Economic Prospects: Weak Investment in Uncertain Times. January. Washington, DC: World Bank.

[51] World Bank. 2017b. Leaning against the Wind: Fiscal Policy in Latin America and the Caribbean in a Historical Perspective. April. Washington, DC: World Bank. 
Figure 1. Debt sustainability indicators

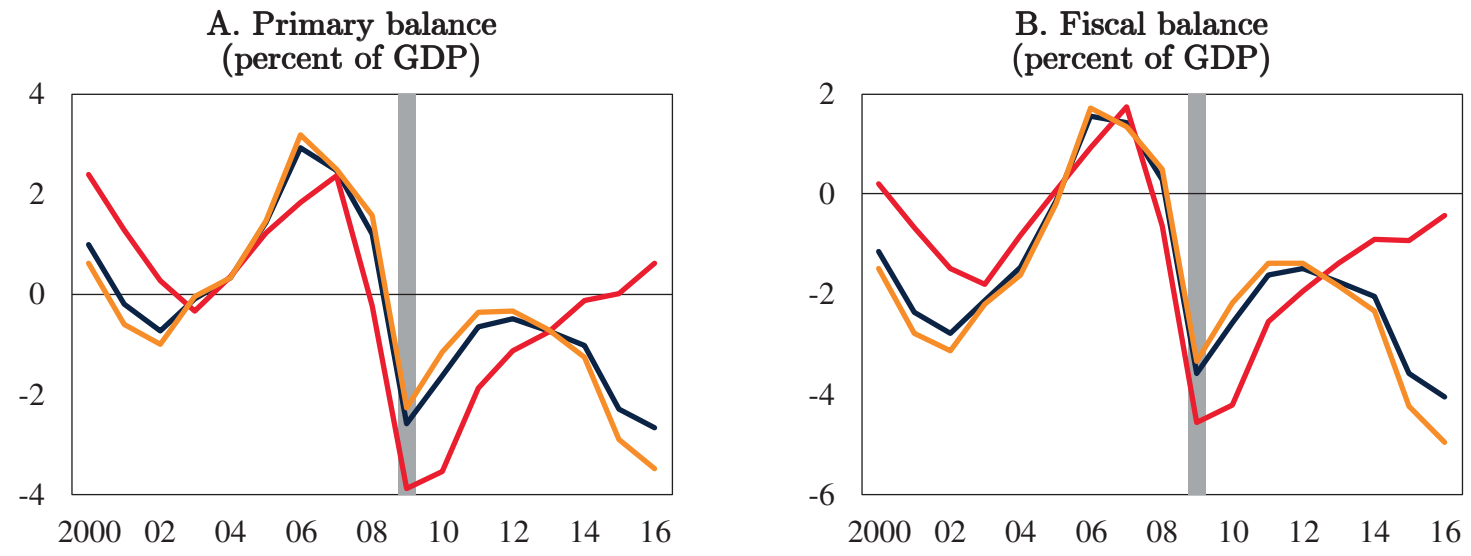

C. General government gross debt (percent of GDP)

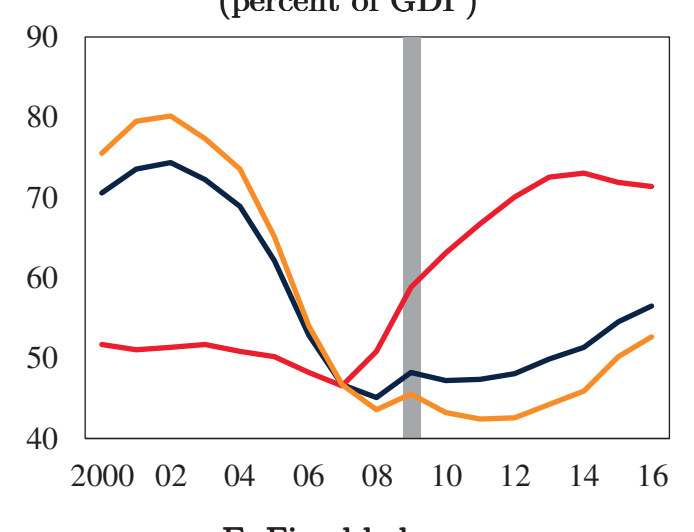

D. Sustainability gap, primary balance (current conditions, percent of GDP)

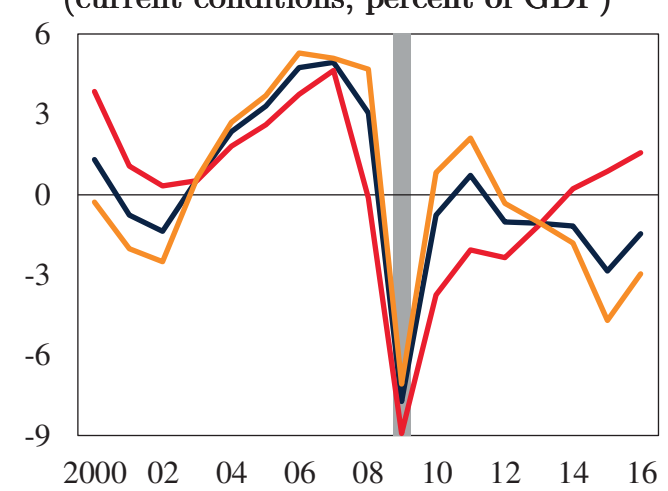

E. Fiscal balance

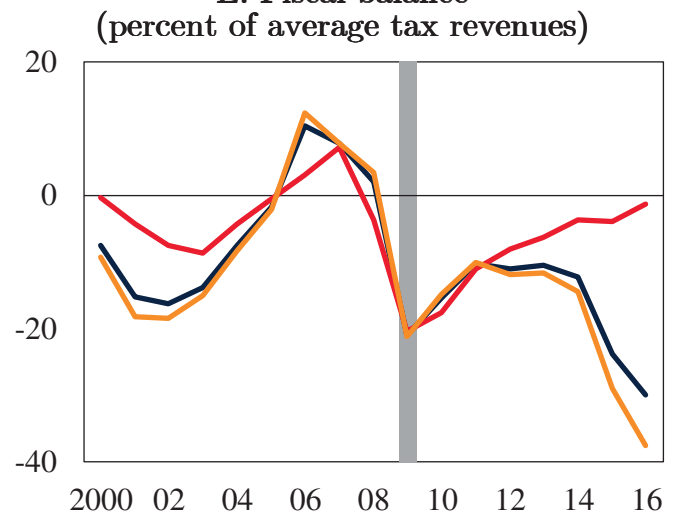

F. General government gross debt (percent of average tax revenues)

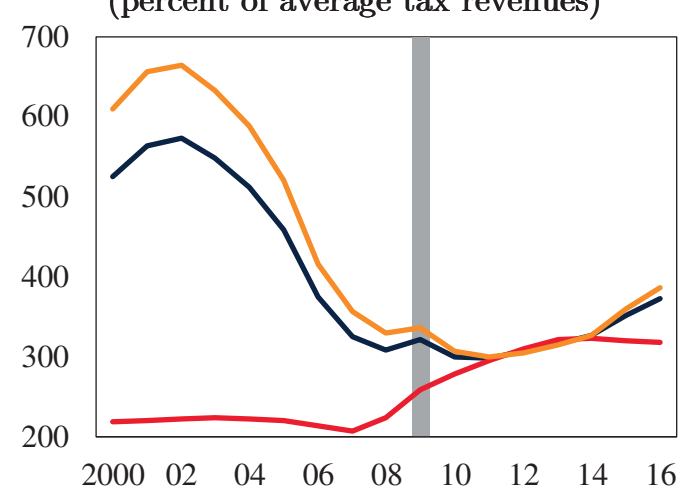

-All countries -Advanced economies -EMDEs

Note: Simple averages. The year of global recession (2009) is shaded in gray. The numbers for 2016 are estimates. E.F. Countries with extremely high ratios are excluded. 
Figure 2. Balance sheet and external and private debt indicators

A. General government debt held by nonresidents (percent of total)

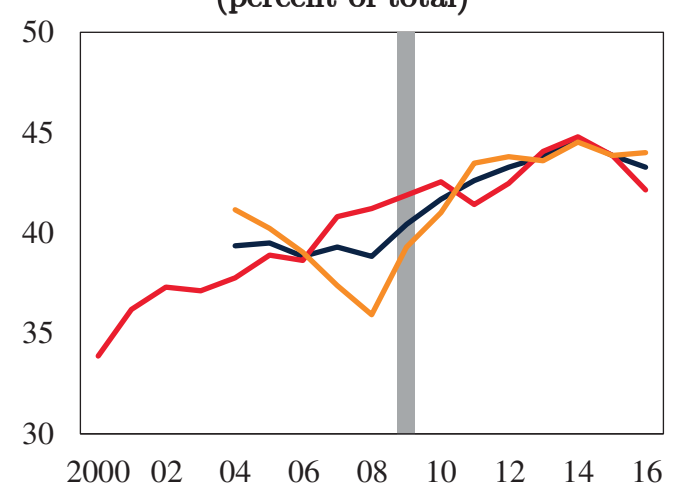

C. Total external debt stocks (percent of GDP)

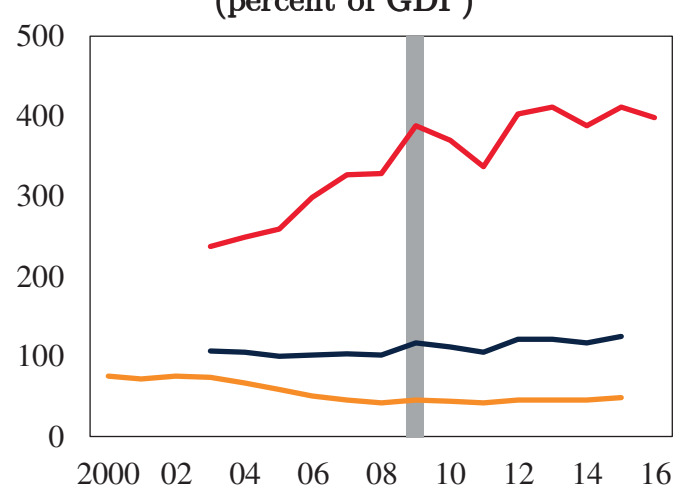

E. Short-term external debt stocks (percent of total)

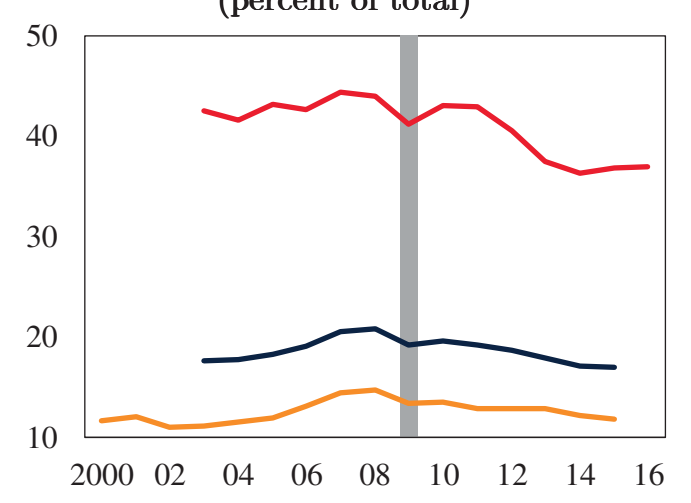

B. Sovereign debt average maturity (years)

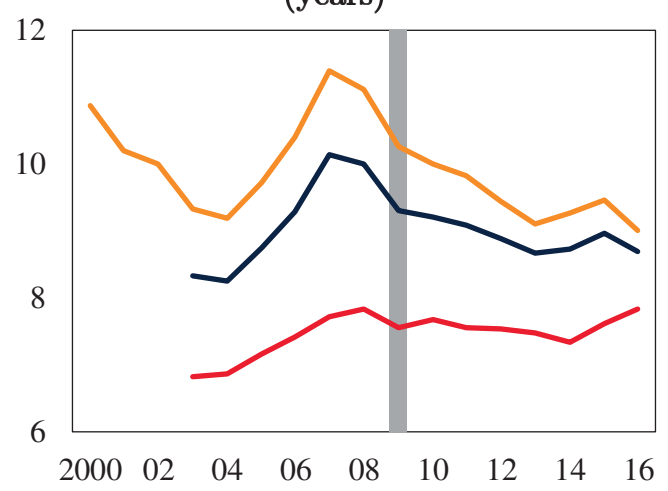

D. External debt in foreign currency (percent of total)

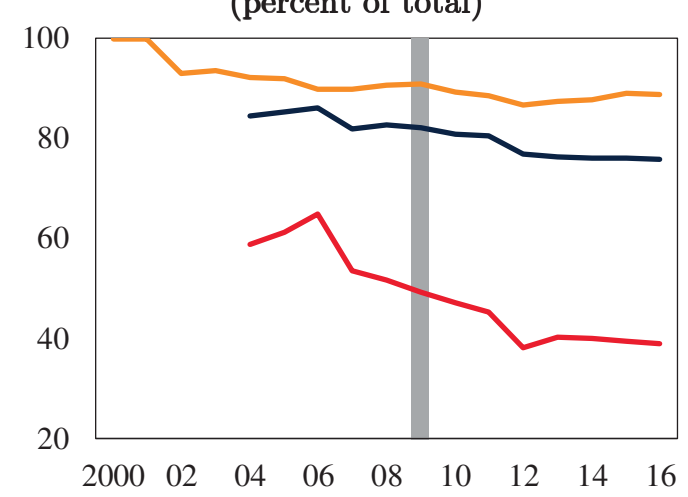

F. Domestic credit to private sector (percent of GDP)

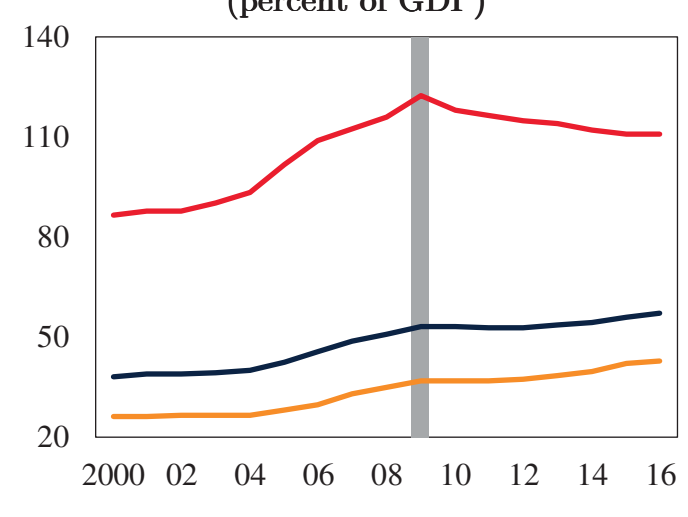

-All countries -Advanced economies

-EMDEs

Note: Simple averages. The year of global recession (2009) is shaded in gray. Data are not presented in some years, because data are not available or the sample size is smaller than in the other years. 
Figure 3. Market perception indicators

\section{A. 5-year dollar sovereign CDS spreads}

(basis points)

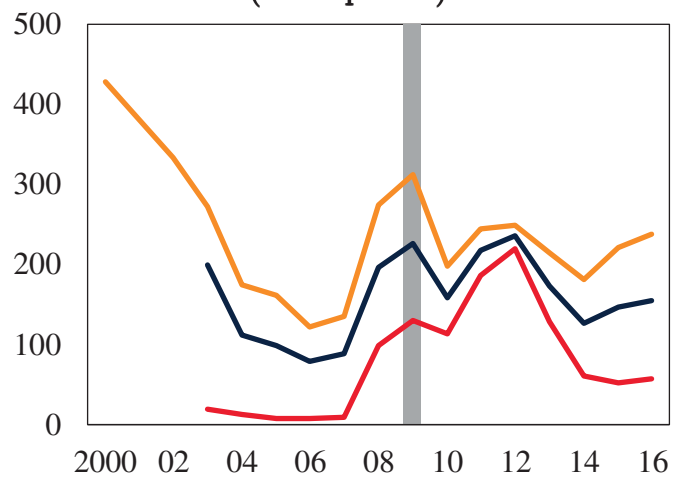

B. Long-term sovereign debt ratings (index ranging from 1 to 21 [best])

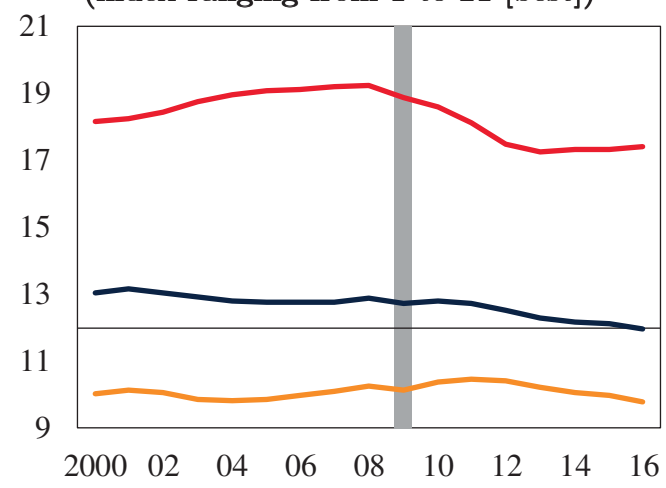

-All countries -Advanced economies -EMDEs

Note: Simple averages. The year of global recession (2009) is shaded in gray.

A. Countries with extremely high spreads are excluded. Due to the small sample size, the data for advanced economies up to 2002 are not presented.

B. The sovereign debt ratings are converted to a numerical scale ranging from 1 to 21 (higher, better rating). The horizontal line is the border between investment grade (above the line) and non-investment grade (below the line). 
Figure 4. Primary balance sustainability gaps

Average by indicator (percent of GDP)

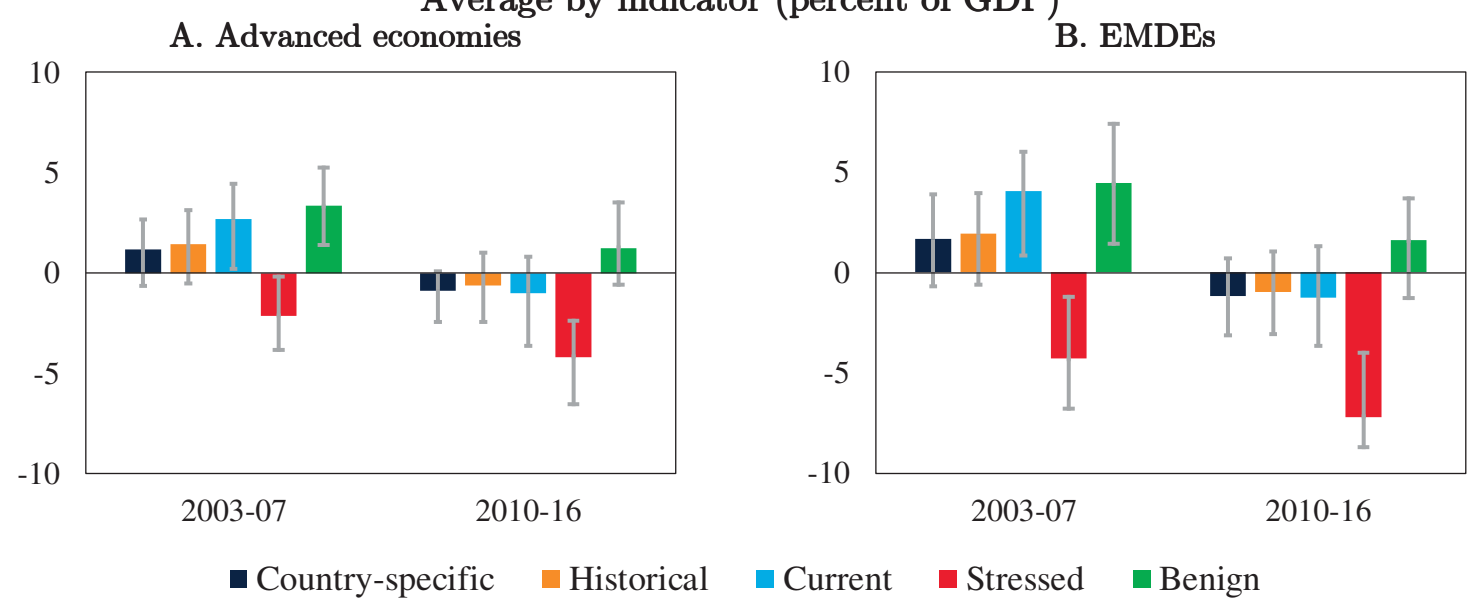

Share of countries with negative sustainability gap (percent of countries)

C. Advanced economies

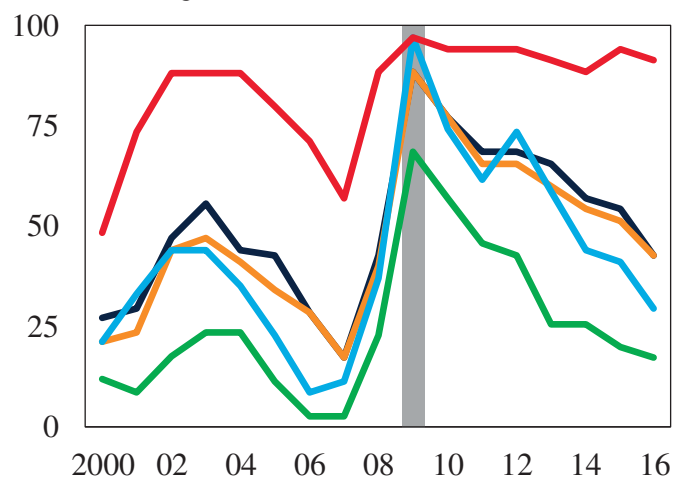

D. EMDEs

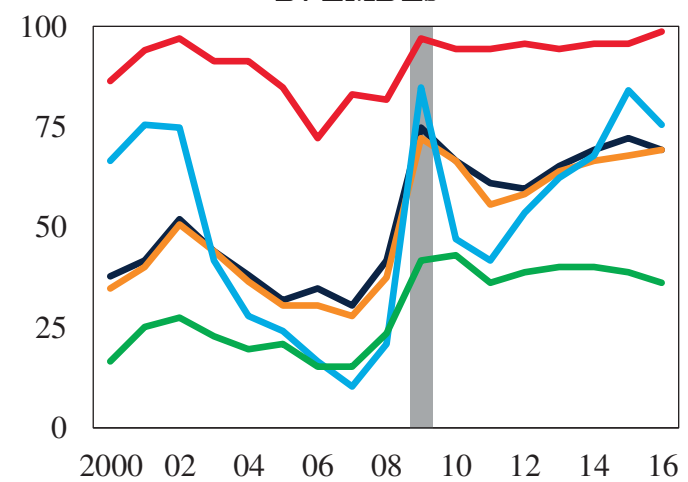

-Country-specific - Historical —Current —Stressed - Benign

Note: A positive gap indicates a primary balance that would diminish government debt, if sustained, over time, while a negative gap shows a primary balance that would increase the stocks of debt. Sustainability gap indicators are computed under five different assumptions for GDP growth rates, interest rates, and target debt ratio. (1) Under country-specific conditions, a sustainability gap is based on country-specific median values in GDP growth rate, interest rate, and debt ratio. (2) Under historical conditions, country-specific median GDP growth and interest rates and median debt ratio by country group (advanced economies and EMDEs) are used. (3) A sustainability gap under current conditions is computed with contemporaneous values in GDP growth and interest rates and medina debt ratio by country group. (4) Stressed conditions are defined as country-specific median GDP growth minus one country-specific standard deviation, country-specific median interest rate plus one country-specific standard deviation, and country-group median debt ratio. (5) A sustainability gap under benign conditions is computed with maximum GDP growth and minimum interest rates based on 10-year moving averages and country-group median debt ratio.

A.B. Period average sustainability gaps in respective country groups. Lines in gray show the interquartile range. C.D. Share of countries in respective groups with negative sustainability gap in respective years (in percent). Data availability varies by year and indicator but they cover at most 35 advanced economies and 72 EMDEs. The year of global recession (2009) is shaded in gray and the numbers for 2016 are estimates. 
Figure 5. Fiscal space indicators, by EMDE commodity exporter status

A. General government gross debt (percent of GDP)

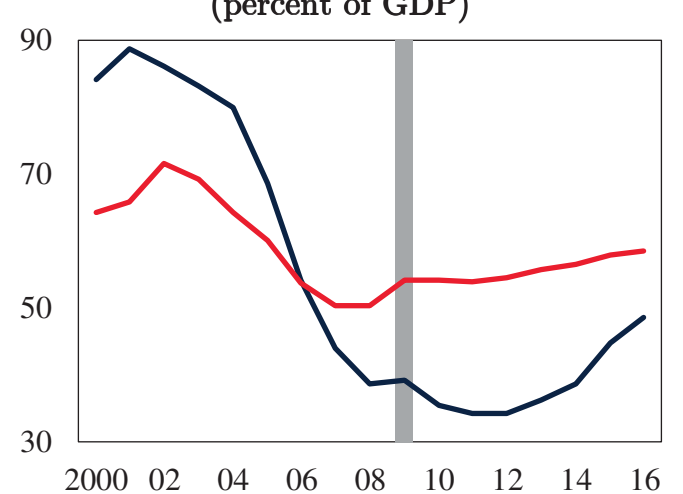

C. Sovereign debt average maturity (years)

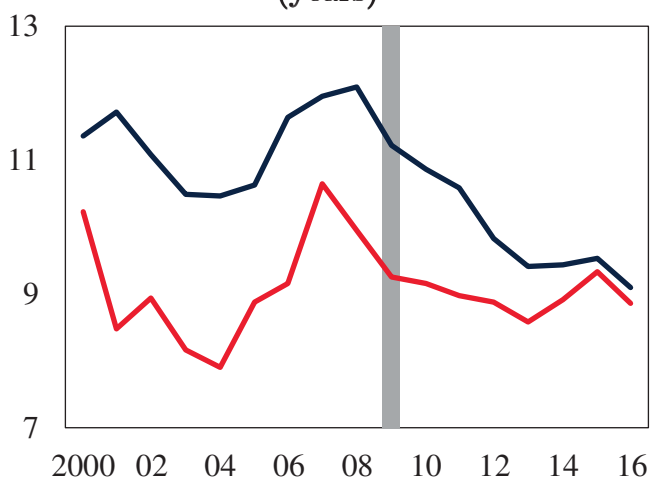

E. Domestic credit to private sector (percent of GDP)

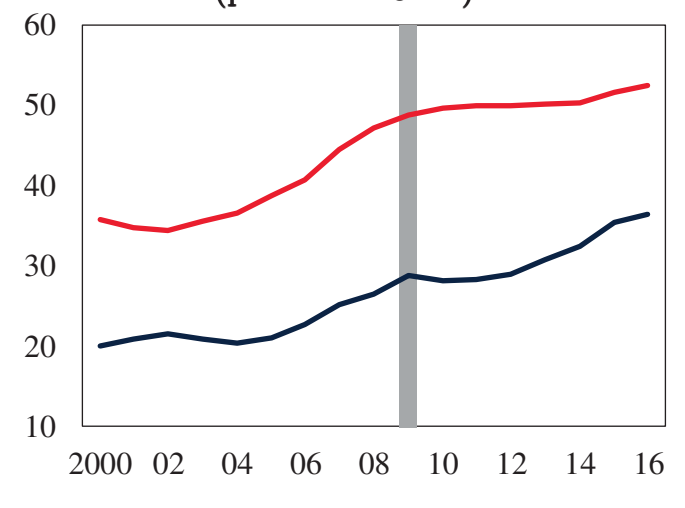

-Commodity exporters
B. Sustainability gap, primary balance (current conditions, percent of GDP)

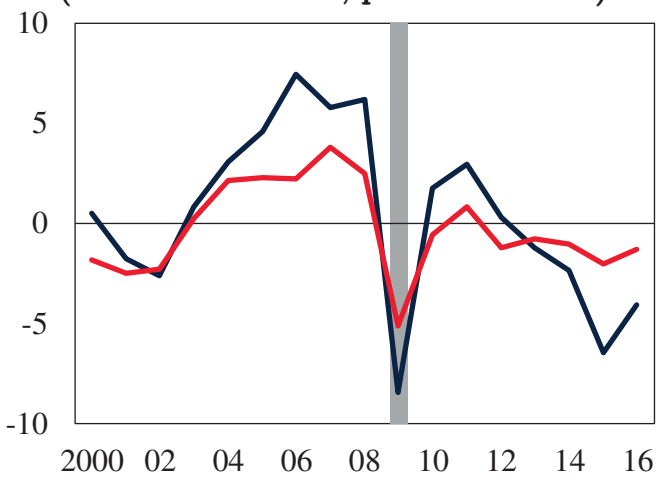

D. Total external debt stocks (percent of GDP)

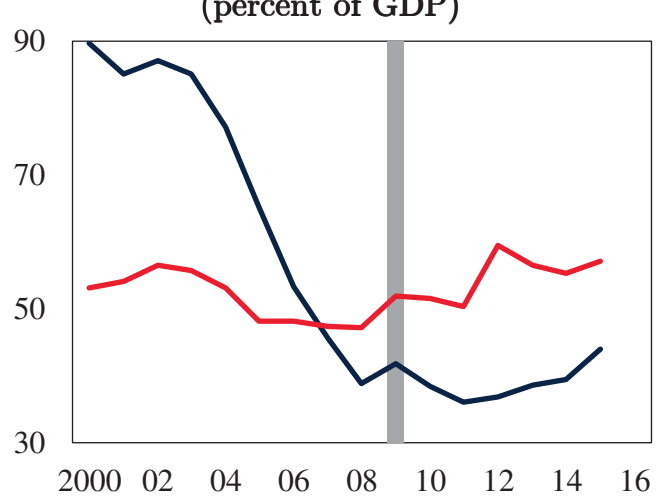

F. Long-term sovereign debt ratings (index ranging from 1 to 21 [best])

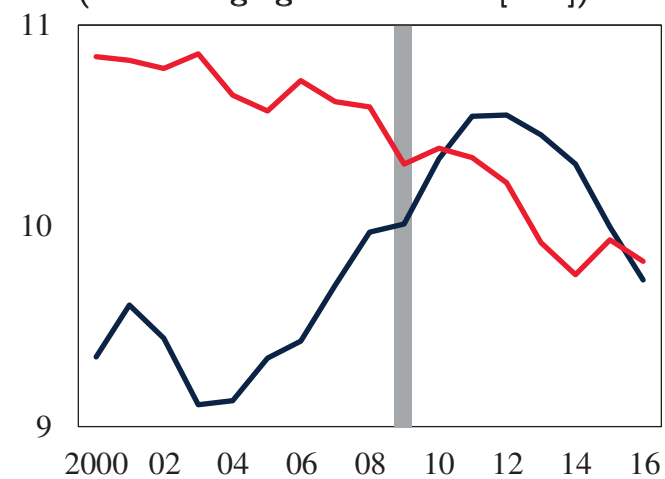

-Commodity importers

Note: Simple averages. The commodity exporter status is based on the criteria used in World Bank (2017a). The year of global recession (2009) is shaded in gray.

A.B. The numbers for 2016 are estimates.

F. The sovereign ratings are converted to a numerical scale ranging from 1 to 21 (higher, better rating). 
Figure 6. Fiscal space around crisis episodes

Advanced economies

EMDEs

A. Sustainability gap, primary balance (current conditions, percent of GDP)
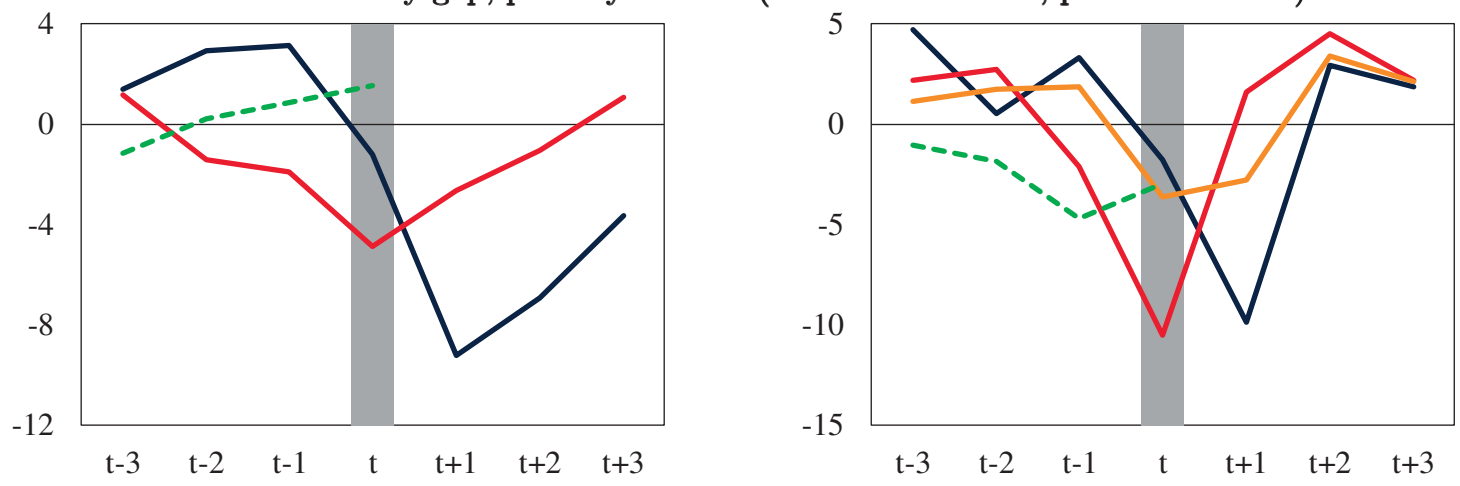

B. Long-term sovereign debt ratings (index ranging from 1 to 21 [best])
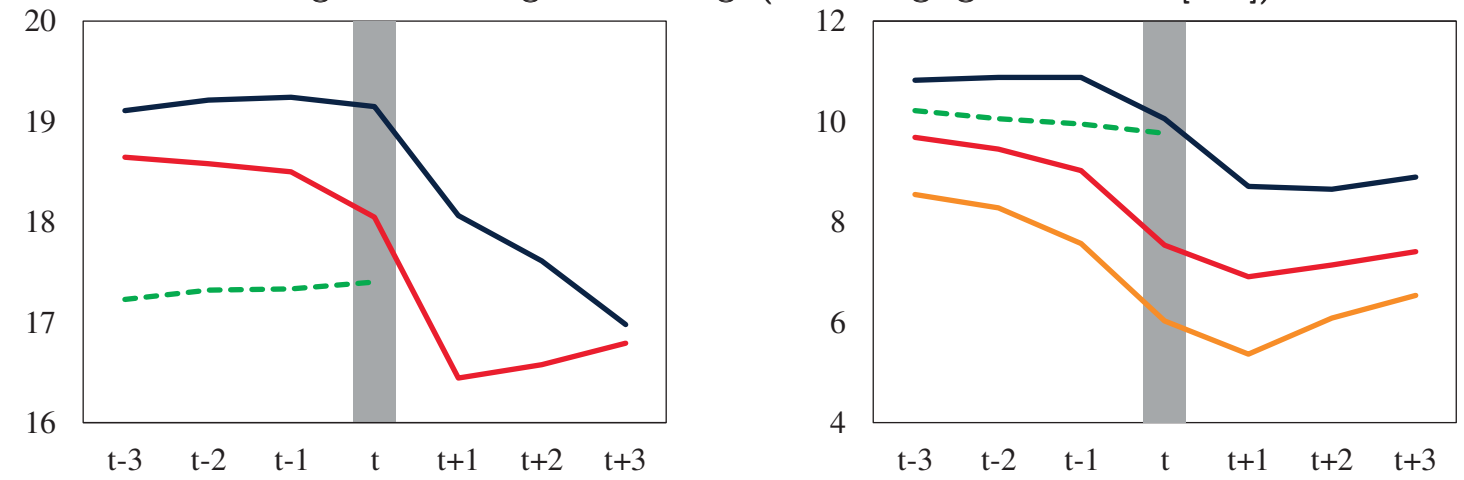

C. Short-term external debt stocks (percent of GDP)
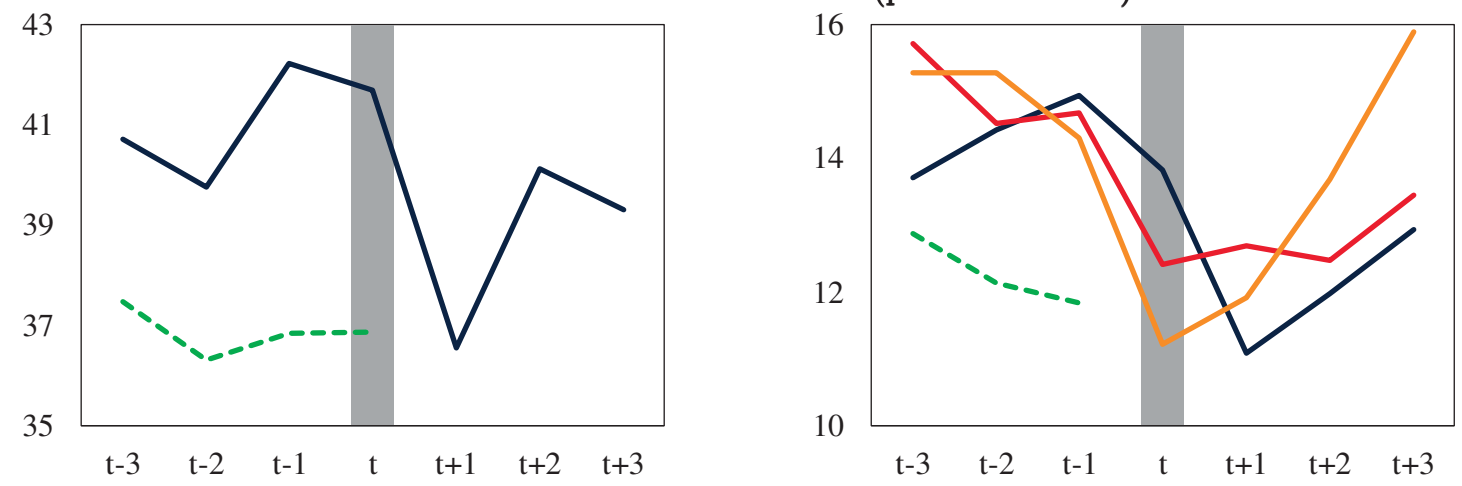

-Banking crises - Currency crises $\longrightarrow$ Debt distress $\quad--$ Current period $(\mathrm{t}=2016)$

Note: Simple averages. Crisis episodes are based on Gourinchas and Obstfeld (2012) and Laeven and Valencia (2013). In any country, when consecutive crises are identified within the next five years, the one associated with the lowest real GDP growth is used. For the full list of crisis episodes used in the figure, refer to Table A8. Due to the small sample size, the aggregate numbers for advanced economies in the case of debt distress episodes are not presented.

B. The sovereign ratings are converted to a numerical scale ranging from 1 to 21 (higher, better rating).

C. Due to the small sample size, the aggregated data for advanced economies in currency crisis episodes are not presented. 
Figure 7. Fiscal space during oil price plunges

A. General government gross debt (percent of GDP)

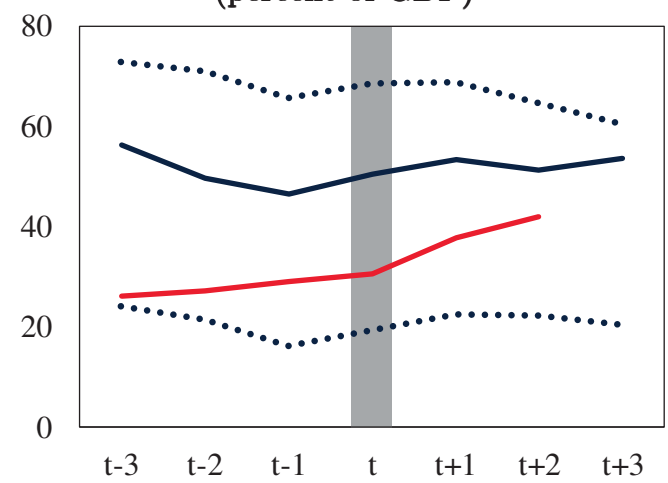

C. Sovereign debt average maturity (years)

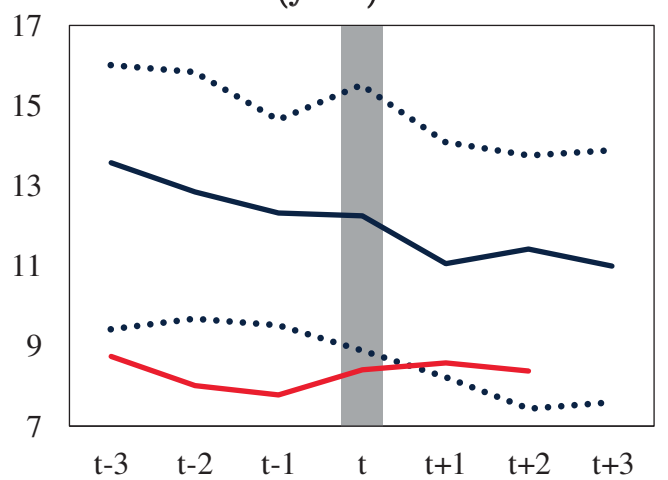

E. Domestic credit to private sector (percent of GDP)

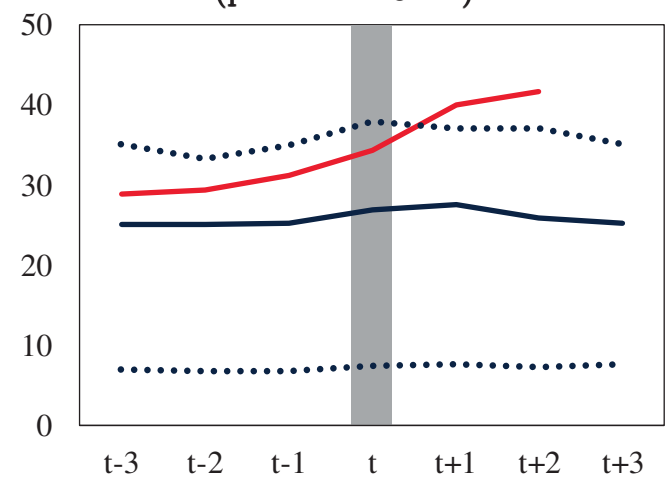

B. Sustainability gap, primary balance (current conditions, percent of GDP)

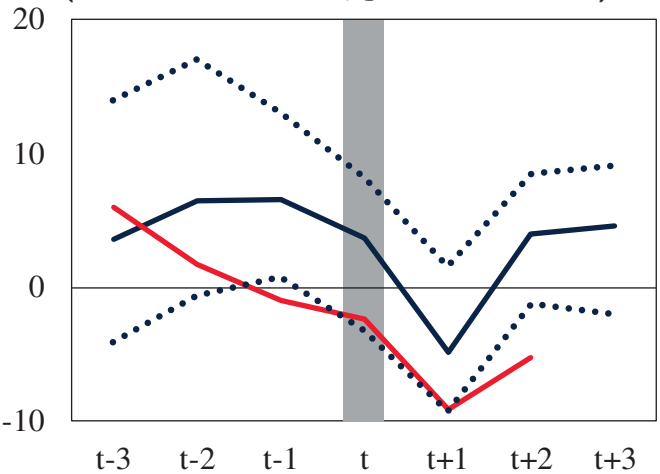

D. Total external debt stocks (percent of GDP)

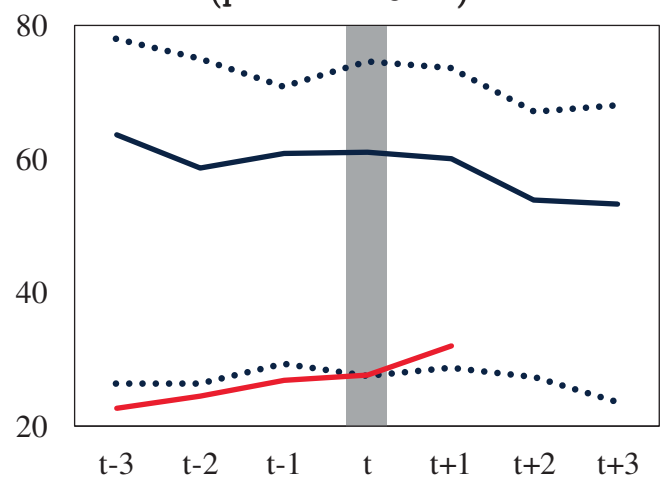

F. Long-term sovereign debt ratings (index ranging from 1 to 21 [best])

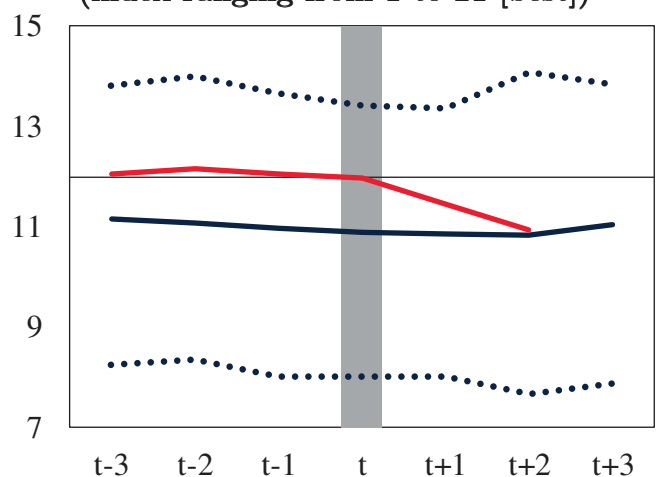

—Past oil price plunges $\cdots \cdot$ Interquartile range — Latest plunge $(t=2014)$

Note: Simple averages. Oil price plunges are episodes where global oil prices dropped significantly over a short period of time and include 1991, 1998, 2001, 2008, and 2014. Data are not presented in some years, because data are not available or the sample size is smaller than in the other years.

F. The sovereign ratings are converted to a numerical scale ranging from 1 to 21 (higher, better rating). The horizontal line is the border between investment grade (above the line) and non-investment grade (below the line). 
Table 1. Variable list, sources and data coverage

\begin{tabular}{|c|c|c|c|c|}
\hline \multirow[b]{2}{*}{ Variable } & \multirow[b]{2}{*}{ Sources } & \multirow[b]{2}{*}{ Obs. } & \multicolumn{2}{|c|}{ Coverage } \\
\hline & & & Country & Year \\
\hline \multicolumn{5}{|l|}{ Government debt sustainability } \\
\hline General government gross debt (percent of GDP) & IMF; World Bank & 3,907 & 186 & $1990-2016$ \\
\hline Primary balance (percent of GDP) & IMF & 4,191 & 184 & $1990-2016$ \\
\hline Cyclically-adjusted balance (percent of potential GDP) & Authors' calculations & 3,610 & 153 & 1990-2016 \\
\hline Fiscal balance (percent of GDP) & IMF & 4,374 & 191 & $1990-2016$ \\
\hline $\begin{array}{l}\text { General government gross debt } \\
\text { (percent of average tax revenues) }\end{array}$ & IMF; OECD; World Bank & 3,868 & 182 & 1990-2016 \\
\hline Fiscal balance (percent of average tax revenues) & IMF; OECD & 4,342 & 187 & 1990-2016 \\
\hline Sustainability gap, fiscal balance (percent of GDP) & Authors' calculations & 4,352 & 191 & 1990-2016 \\
\hline $\begin{array}{l}\text { Sustainability gap, primary balance, country-specific conditions } \\
\text { (percent of GDP) }\end{array}$ & Authors' calculations & 2,476 & 107 & 1990-2016 \\
\hline $\begin{array}{l}\text { Sustainability gap, primary balance, historical conditions } \\
\text { (percent of GDP) }\end{array}$ & Authors' calculations & 2,476 & 107 & 1990-2016 \\
\hline $\begin{array}{l}\text { Sustainability gap, primary balance, current conditions } \\
\text { (percent of GDP) }\end{array}$ & Authors' calculations & 1,961 & 107 & 1990-2016 \\
\hline $\begin{array}{l}\text { Sustainability gap, primary balance, stressed conditions } \\
\text { (percent of GDP) }\end{array}$ & Authors' calculations & 2,476 & 107 & 1990-2016 \\
\hline $\begin{array}{l}\text { Sustainability gap, primary balance, benign conditions } \\
\quad \text { (percent of GDP) }\end{array}$ & Authors' calculations & 2,476 & 107 & 1990-2016 \\
\hline \multicolumn{5}{|l|}{ Balance sheet composition } \\
\hline $\begin{array}{l}\text { General government debt in foreign currency } \\
\text { (percent of total) } 1 /\end{array}$ & OECD; World Bank & 505 & 48 & 1990-2016 \\
\hline Debt securities held by nonresidents (percent of total) & JEDH; BIS & 640 & 43 & 2001-2016 \\
\hline $\begin{array}{l}\text { General government debt held by nonresidents } \\
\text { (percent of total) } 1 /\end{array}$ & $\begin{array}{l}\text { Arslanalp and Tsuda (2014a, } \\
\text { 2014b); World Bank }\end{array}$ & 893 & 73 & $1995-2016$ \\
\hline $\begin{array}{l}\text { Concessional external debt stocks } \\
\text { (percent of general government gross debt) }\end{array}$ & IMF; World Bank & 2,211 & 121 & $1990-2015$ \\
\hline Sovereign debt average maturity (years) & Bloomberg; J.P. Morgan & 1,132 & 89 & 1993-2016 \\
\hline $\begin{array}{l}\text { Central government debt maturing in } 12 \text { months or less } \\
\text { (percent of GDP) }\end{array}$ & Bloomberg; IMF & 795 & 146 & 2011-2016 \\
\hline \multicolumn{5}{|l|}{ External and private sector debt } \\
\hline Total external debt stocks (percent of GDP) & IMF; World Bank & 3,727 & 170 & 1990-2016 \\
\hline External debt in foreign currency (percent of total) & World Bank & 391 & 39 & 1998-2016 \\
\hline Private external debt stocks (percent of GDP) & IMF; World Bank & 3,727 & 170 & 1990-2016 \\
\hline Domestic credit to private sector (percent of GDP) & BIS; IMF; World Bank & 4,636 & 185 & 1990-2016 \\
\hline Short-term external debt stocks (percent of total) & World Bank & 3,785 & 170 & 1990-2016 \\
\hline Short-term external debt stocks (percent of reserves) & IMF; World Bank & 3,597 & 164 & 1990-2016 \\
\hline Total external debt stocks (percent of reserves) & IMF; World Bank & 3,598 & 164 & 1990-2016 \\
\hline Total external debt stocks (percent of reserves excluding gold) & IMF; World Bank & 3,599 & 164 & 1990-2016 \\
\hline \multicolumn{5}{|l|}{ Market perception } \\
\hline 5-year sovereign CDS spreads (basis points) & Bloomberg; J.P. Morgan & 930 & 71 & 1997-2016 \\
\hline $\begin{array}{l}\text { Foreign currency long-term sovereign debt ratings } \\
\quad \text { (index ranging from } 1 \text { to } 21 \text { [best]) }\end{array}$ & Bloomberg & 2,786 & 148 & 1990-2016 \\
\hline
\end{tabular}

Note: Year coverage differs by country in each variable. 1/ Data cover public sector, instead of general government, for Kenya and Uganda. 
Table 2. Country coverage and groups

\begin{tabular}{|c|c|}
\hline Advanced economies (41) & $\begin{array}{l}\text { Andorra; Australia; Austria; Belgium; Canada; Cyprus; Czech } \\
\text { Republic; Denmark; Estonia; Finland; France; Germany; Greece; } \\
\text { Hong Kong SAR, China; Iceland; Ireland; Isle of Man; Israel; } \\
\text { Italy; Japan; Korea, Rep.; Latvia; Liechtenstein; Lithuania; } \\
\text { Luxembourg; Macao SAR, China; Malta; Netherlands; New } \\
\text { Zealand; Norway; Portugal; Puerto Rico; San Marino; Singapore; } \\
\text { Slovak Republic; Slovenia; Spain; Sweden; Switzerland; United } \\
\text { Kingdom; United States }\end{array}$ \\
\hline \multirow{2}{*}{\multicolumn{2}{|c|}{$\begin{array}{c}\text { Emerging market and developing economies (EMDEs) } \\
\text { Commodity exporters }(91)\end{array}$}} \\
\hline & \\
\hline $\begin{array}{l}\text { Commodity exporters ( } \\
\text { Energy exporters } \\
(36)\end{array}$ & $\begin{array}{l}\text { Albania; Algeria; Angola; Azerbaijan; Bahrain; Bolivia; Brunei } \\
\text { Darussalam; Cameroon; Chad; Colombia; Congo, Rep; Ecuador; } \\
\text { Equatorial Guinea; Gabon; Ghana; Indonesia; Iran, Islamic Rep; } \\
\text { Iraq; Kazakhstan; Kuwait; Libya; Malaysia; Myanmar; Nigeria; } \\
\text { Oman; Qatar; Russian Federation; Saudi Arabia; South Sudan; } \\
\text { Sudan; Timor-Leste; Trinidad \& Tobago; Turkmenistan; United } \\
\text { Arab Emirates; Venezuela, RB; Yemen, Rep. }\end{array}$ \\
\hline $\begin{array}{l}\text { Other commodity } \\
\text { exporters }(55)\end{array}$ & $\begin{array}{l}\text { Argentina; Armenia; Belize; Benin; Botswana; Brazil; Burkina } \\
\text { Faso; Burundi; Central African Rep.; Chile; Congo, Dem. Rep.; } \\
\text { Costa Rica; Cote d’Ivoire; Ethiopia; Gambia, The; Guatemala; } \\
\text { Guinea; Guinea-Bissau; Guyana; Honduras; Kenya; Kyrgyz } \\
\text { Republic; Lao PDR; Liberia; Madagascar; Malawi; Mali; } \\
\text { Mauritania; Mongolia; Morocco; Mozambique; Namibia; } \\
\text { Nicaragua; Niger; Papua New Guinea; Paraguay; Peru; Rwanda; } \\
\text { Sao Tome \& Principe; Senegal; Sierra Leone; South Africa; Sri } \\
\text { Lanka; Suriname; Tajikistan; Tanzania; Togo; Tonga; Uganda; } \\
\text { Ukraine; Uruguay; Uzbekistan; West Bank \& Gaza; Zambia; } \\
\text { Zimbabwe }\end{array}$ \\
\hline $\begin{array}{l}\text { Commodity importers } \\
(68)\end{array}$ & $\begin{array}{l}\text { Afghanistan; Antigua \& Barbuda; Aruba; Bahamas, The; } \\
\text { Bangladesh; Barbados; Belarus; Bermuda; Bhutan; Bosnia \& } \\
\text { Herzegovina; Bulgaria; Cabo Verde; Cambodia; Cayman Islands; } \\
\text { China; Comoros; Croatia; Cuba; Djibouti; Dominica; Dominican } \\
\text { Republic; Egypt, Arab Rep.; El Salvador; Eritrea; Fiji; Georgia; } \\
\text { Grenada; Haiti; Hungary; India; Jamaica; Jordan; Kiribati; } \\
\text { Kosovo; Lebanon; Lesotho; Macedonia, FYR; Maldives; Marshall } \\
\text { Islands; Mauritius; Mexico; Micronesia, Fed. States; Moldova; } \\
\text { Montenegro; Nauru; Nepal; Pakistan; Palau; Panama; Philippines; } \\
\text { Poland; Romania; Samoa; Serbia; Seychelles; Solomon Islands; } \\
\text { Somalia; St. Kitts \& Nevis; St. Lucia; St. Vincent \& the } \\
\text { Grenadines; Swaziland; Syrian Arab Republic; Thailand; Tunisia; } \\
\text { Turkey; Tuvalu; Vanuatu; Vietnam }\end{array}$ \\
\hline
\end{tabular}

Note: The number of countries in each country group is in parenthesis. 
Table 3. Correlations among indicators of fiscal space

A. All countries

\begin{tabular}{l||cccc}
\hline & $\begin{array}{c}\text { Government debt } \\
\text { sustainability }\end{array}$ & $\begin{array}{c}\text { Balance sheet } \\
\text { composition }\end{array}$ & $\begin{array}{c}\text { External and } \\
\text { private sector debt }\end{array}$ & $\begin{array}{c}\text { Market } \\
\text { perception }\end{array}$ \\
\hline \hline Government debt sustainability & 0.58 & & & \\
Balance sheet composition & {$[66,66]$} & & & \\
External and private sector debt & 0.09 & 0.27 & & \\
& {$[36,72]$} & {$[12,15]$} & 0.42 & \\
Market perception & 0.06 & 0.25 & {$[28,28]$} & 0.58 \\
& {$[55,96]$} & {$[38,48]$} & 0.27 & {$[1,1]$} \\
\hline
\end{tabular}

\section{B. Advanced economies}

\begin{tabular}{|c|c|c|c|c|}
\hline & $\begin{array}{c}\text { Government debt } \\
\text { sustainability }\end{array}$ & $\begin{array}{c}\text { Balance sheet } \\
\text { composition }\end{array}$ & $\begin{array}{c}\text { External and } \\
\text { private sector debt }\end{array}$ & $\begin{array}{c}\text { Market } \\
\text { perception }\end{array}$ \\
\hline Government debt sustainability & $\begin{array}{c}0.74 \\
{[66,66]}\end{array}$ & & & \\
\hline Balance sheet composition & $\begin{array}{c}0.13 \\
{[28,60]}\end{array}$ & $\begin{array}{c}0.22 \\
{[6,10]}\end{array}$ & & \\
\hline External and private sector debt & $\begin{array}{c}0.10 \\
{[30,96]}\end{array}$ & $\begin{array}{c}0.18 \\
{[23,40]}\end{array}$ & $\begin{array}{c}0.45 \\
{[19,28]}\end{array}$ & \\
\hline Market perception & $\begin{array}{c}0.22 \\
{[22,24]}\end{array}$ & $\begin{array}{c}0.16 \\
{[6,10]}\end{array}$ & $\begin{array}{c}0.15 \\
{[6,16]}\end{array}$ & $\begin{array}{l}0.52 \\
{[1,1]}\end{array}$ \\
\hline \multicolumn{5}{|c|}{ C. EMDEs } \\
\hline & $\begin{array}{l}\text { Government debt } \\
\text { sustainability }\end{array}$ & $\begin{array}{c}\text { Balance sheet } \\
\text { composition }\end{array}$ & $\begin{array}{c}\text { External and } \\
\text { private sector debt }\end{array}$ & $\begin{array}{c}\text { Market } \\
\text { perception }\end{array}$ \\
\hline Government debt sustainability & $\begin{array}{c}0.53 \\
{[66,66]}\end{array}$ & & & \\
\hline Balance sheet composition & $\begin{array}{c}0.13 \\
{[38,72]}\end{array}$ & $\begin{array}{c}0.28 \\
{[9,15]}\end{array}$ & & \\
\hline External and private sector debt & $\begin{array}{c}0.06 \\
{[41,96]}\end{array}$ & $\begin{array}{c}0.16 \\
{[27,48]}\end{array}$ & $\begin{array}{c}0.24 \\
{[24,28]}\end{array}$ & \\
\hline Market perception & $\begin{array}{c}0.14 \\
{[18,24]}\end{array}$ & $\begin{array}{c}0.24 \\
{[7,12]}\end{array}$ & $\begin{array}{c}0.19 \\
{[11,16]}\end{array}$ & $\begin{array}{l}0.51 \\
{[1,1]}\end{array}$ \\
\hline
\end{tabular}

Note: Average correlation coefficients between variables in respective groups. The numbers before and after the comma in bracket are, respectively, the number of statistically significant coefficients from zero at least at the 5-percent level and the total number of individual coefficients considered. Because of differences in coefficient signs, absolute values are used to compute averages. When computing individual correlations, observations smaller than the 1st percentile and larger than the 99th percentile are excluded. Due to the potential trends in the level, indicators of government debt level (percent of GDP and percent of tax revenues) are first difference series and multiplied by negative one to make it in line with fiscal and primary balances. All the individual coefficients are presented in Table A3. 
Table 4. Descriptive statistics of fiscal space, all countries

\begin{tabular}{|c|c|c|c|c|c|c|c|c|c|}
\hline All countries & Full period & 1990s & $2000-07$ & $2008-16$ & All countries & Full period & 1990s & $2000-07$ & $2008-16$ \\
\hline Government debt sustainability & & & & & Balance sheet composition (continued) & & & & \\
\hline $\begin{array}{l}\text { General government gross debt } \\
\quad \text { (percent of GDP) }\end{array}$ & $\begin{array}{r}58.0 \\
{[49.6]}\end{array}$ & $\begin{array}{r}63.0 \\
{[42.9]}\end{array}$ & $\begin{array}{r}64.8 \\
{[64.7]}\end{array}$ & $\begin{array}{r}49.8 \\
{[34.7]}\end{array}$ & $\begin{array}{l}\text { Concessional external debt stocks } \\
\text { (percent of general government gross debt) }\end{array}$ & $\begin{array}{r}37.1 \\
{[26.7]}\end{array}$ & $\begin{array}{r}38.5 \\
{[25.3]}\end{array}$ & $\begin{array}{r}39.8 \\
{[27.7]}\end{array}$ & $\begin{array}{r}33.9 \\
{[26.1]}\end{array}$ \\
\hline $\begin{array}{l}\text { Primary balance } \\
\quad \text { (percent of GDP) }\end{array}$ & $\begin{array}{r}-0.7 \\
{[13.4]}\end{array}$ & $\begin{array}{r}-2.1 \\
{[23.3]}\end{array}$ & $\begin{array}{r}0.9 \\
{[6.7]}\end{array}$ & $\begin{array}{l}-1.2 \\
{[6.2]}\end{array}$ & $\begin{array}{l}\text { Sovereign debt average maturity } \\
\text { (years) }\end{array}$ & $\begin{array}{r}9.5 \\
{[4.7]}\end{array}$ & $\begin{array}{r}12.6 \\
{[5.5]}\end{array}$ & $\begin{array}{r}9.3 \\
{[4.9]}\end{array}$ & $\begin{array}{r}9.0 \\
{[4.2]}\end{array}$ \\
\hline $\begin{array}{l}\text { Cyclically-adjusted balance } \\
\text { (percent of potential GDP) }\end{array}$ & $\begin{array}{r}-2.5 \\
{[12.0]}\end{array}$ & $\begin{array}{r}-4.1 \\
{[20.5]}\end{array}$ & $\begin{array}{r}-1.1 \\
{[5.9]}\end{array}$ & $\begin{array}{r}-2.6 \\
{[5.2]}\end{array}$ & $\begin{array}{l}\text { Central government debt maturing in } \\
12 \text { months or less (percent of GDP) }\end{array}$ & $\begin{array}{r}6.7 \\
{[7.7]}\end{array}$ & $\begin{array}{c}\cdots \\
{[\ldots]}\end{array}$ & $\begin{array}{c}\cdots \\
{[\ldots]}\end{array}$ & $\begin{array}{r}6.7 \\
{[7.7]}\end{array}$ \\
\hline $\begin{array}{l}\text { Fiscal balance } \\
\quad \text { (percent of GDP) }\end{array}$ & $\begin{array}{r}-2.4 \\
{[13.5]}\end{array}$ & $\begin{array}{r}-4.4 \\
{[22.7]}\end{array}$ & $\begin{array}{r}-0.9 \\
{[7.4]}\end{array}$ & $\begin{array}{r}-2.3 \\
{[7.2]}\end{array}$ & External and private sector debt & & & & \\
\hline $\begin{array}{l}\text { General government gross debt } \\
\text { (percent of average tax revenues) }\end{array}$ & $\begin{array}{r}497.0 \\
{[1,171.8]}\end{array}$ & $\begin{array}{r}588.0 \\
{[1,274.8]}\end{array}$ & $\begin{array}{r}588.8 \\
{[1,559.5]}\end{array}$ & $\begin{array}{r}371.4 \\
{[561.6]}\end{array}$ & $\begin{array}{l}\text { Total external debt stocks } \\
\text { (percent of GDP) }\end{array}$ & $\begin{array}{r}99.1 \\
{[303.3]}\end{array}$ & $\begin{array}{r}74.7 \\
{[91.6]}\end{array}$ & $\begin{array}{r}97.4 \\
{[255.2]}\end{array}$ & $\begin{array}{r}119.6 \\
{[423.3]}\end{array}$ \\
\hline $\begin{array}{l}\text { Fiscal balance } \\
\text { (percent of average tax revenues) }\end{array}$ & $\begin{array}{r}-9.9 \\
{[364.8}\end{array}$ & $\begin{array}{r}-56.7 \\
{[532.2]}\end{array}$ & $\begin{array}{r}16.8 \\
{[276.6]}\end{array}$ & $\begin{array}{r}0.5 \\
{[268.9]}\end{array}$ & $\begin{array}{l}\text { External debt in foreign currency } \\
\quad \text { (percent of total) } 1 /\end{array}$ & $\begin{array}{r}80.6 \\
{[24.8]}\end{array}$ & $\begin{array}{r}95.0 \\
{[10.6]}\end{array}$ & $\begin{array}{r}86.5 \\
{[20.3]}\end{array}$ & $\begin{array}{r}78.0 \\
{[26.1]}\end{array}$ \\
\hline $\begin{array}{l}\text { Sustainability gap, fiscal balance } \\
\text { (percent of GDP) }\end{array}$ & $\begin{array}{r}1.3 \\
{[14.7]}\end{array}$ & $\begin{array}{r}-0.2 \\
{[23.5]}\end{array}$ & $\begin{array}{r}3.8 \\
{[9.0]}\end{array}$ & $\begin{array}{r}0.3 \\
{[9.2]}\end{array}$ & $\begin{array}{l}\text { Private external debt stocks } \\
\quad \text { (percent of GDP) }\end{array}$ & $\begin{array}{r}52.4 \\
{[297.0]}\end{array}$ & $\begin{array}{r}9.6 \\
{[19.4]}\end{array}$ & $\begin{array}{r}49.2 \\
{[253.7]}\end{array}$ & $\begin{array}{r}88.7 \\
{[417.7]}\end{array}$ \\
\hline $\begin{array}{l}\text { Sustainability gap, primary balance, country- } \\
\text { specific conditions (percent of GDP) }\end{array}$ & $\begin{array}{r}0.2 \\
{[4.6]}\end{array}$ & $\begin{array}{r}0.5 \\
{[4.4]}\end{array}$ & $\begin{array}{r}1.2 \\
{[4.6]}\end{array}$ & $\begin{array}{r}-1.0 \\
{[4.4]}\end{array}$ & $\begin{array}{l}\text { Domestic credit to private sector } \\
\text { (percent of GDP) }\end{array}$ & $\begin{array}{r}43.8 \\
{[40.6]}\end{array}$ & $\begin{array}{r}35.9 \\
{[34.9]}\end{array}$ & $\begin{array}{r}41.6 \\
{[39.9]}\end{array}$ & $\begin{array}{r}53.8 \\
{[44.3]}\end{array}$ \\
\hline $\begin{array}{l}\text { Sustainability gap, primary balance, historical } \\
\text { conditions (percent of GDP) }\end{array}$ & $\begin{array}{r}0.4 \\
{[4.6]}\end{array}$ & $\begin{array}{r}0.7 \\
{[4.3]}\end{array}$ & $\begin{array}{r}1.5 \\
{[4.6]}\end{array}$ & $\begin{array}{r}-0.8 \\
{[4.4]}\end{array}$ & $\begin{array}{l}\text { Short-term external debt stocks } \\
\quad \text { (percent of total) }\end{array}$ & $\begin{array}{r}16.2 \\
{[16.5]}\end{array}$ & $\begin{array}{r}12.0 \\
{[13.4]}\end{array}$ & $\begin{array}{r}17.2 \\
{[17.4]}\end{array}$ & $\begin{array}{r}18.9 \\
{[17.2]}\end{array}$ \\
\hline $\begin{array}{l}\text { Sustainability gap, primary balance, current } \\
\text { conditions (percent of GDP) }\end{array}$ & $\begin{array}{r}0.0 \\
{[6.3]}\end{array}$ & $\begin{array}{r}-0.6 \\
{[5.5]}\end{array}$ & $\begin{array}{r}2.0 \\
{[6.1]}\end{array}$ & $\begin{array}{r}-1.4 \\
{[6.3]}\end{array}$ & $\begin{array}{l}\text { Short-term external debt stocks } \\
\text { (percent of reserves) }\end{array}$ & $\begin{array}{r}1,943.1 \\
{[20,394.1]}\end{array}$ & $\begin{array}{r}1,594.2 \\
{[15,665.6]}\end{array}$ & $\begin{array}{r}2,890.9 \\
{[29,896.7]}\end{array}$ & $\begin{array}{r}1,423.5 \\
{[12,215.7]}\end{array}$ \\
\hline $\begin{array}{l}\text { Sustainability gap, primary balance, stressed } \\
\text { conditions (percent of GDP) }\end{array}$ & $\begin{array}{r}-4.8 \\
{[5.4}\end{array}$ & $\begin{array}{r}-4.0 \\
{[4.8]}\end{array}$ & $\begin{array}{r}-3.8 \\
{[5.2]}\end{array}$ & $\begin{array}{r}-6.1 \\
{[5.7]}\end{array}$ & $\begin{array}{l}\text { Total external debt stocks } \\
\text { (percent of reserves) }\end{array}$ & $\begin{array}{r}5,256.2 \\
{[42,359.2]}\end{array}$ & $\begin{array}{r}5,711.2 \\
{[37,649.0]}\end{array}$ & $\begin{array}{r}6,020.9 \\
{[55,484.4]}\end{array}$ & $\begin{array}{r}4,263.9 \\
{[31,893.3]}\end{array}$ \\
\hline $\begin{array}{l}\text { Sustainability gap, primary balance, benign } \\
\text { conditions (percent of GDP) }\end{array}$ & $\begin{array}{r}2.6 \\
{[5.2]}\end{array}$ & $\begin{array}{r}2.8 \\
{[4.8]}\end{array}$ & $\begin{array}{r}3.8 \\
{[5.3]}\end{array}$ & $\begin{array}{r}1.5 \\
{[5.2]}\end{array}$ & $\begin{array}{l}\text { Total external debt stocks } \\
\quad \text { (percent of reserves excluding gold) }\end{array}$ & $\begin{array}{r}7,929.0 \\
{[59,726.6]}\end{array}$ & $\begin{array}{r}11,641.0 \\
{[74,895.0]}\end{array}$ & $\begin{array}{r}7,287.6 \\
{[65,684.4]}\end{array}$ & $\begin{array}{r}5,571.7 \\
{[36,627.3]}\end{array}$ \\
\hline Balance sheet composition & & & & & Mark & & & & \\
\hline $\begin{array}{l}\text { General government debt in foreign currency } \\
\text { (percent of total) }\end{array}$ & $\begin{array}{r}26.8 \\
{[29.7]}\end{array}$ & $\begin{array}{r}10.6 \\
{[13.2]}\end{array}$ & $\begin{array}{r}12.9 \\
{[23.2]}\end{array}$ & $\begin{array}{r}33.5 \\
{[30.7]}\end{array}$ & $\begin{array}{l}5 \text {-year sovereign CDS spreads } \\
\text { (basis points) }\end{array}$ & $\begin{array}{r}461.4 \\
{[2,962.0]}\end{array}$ & $\begin{array}{r}822.9 \\
{[1,491.9]}\end{array}$ & $\begin{array}{r}193.6 \\
{[304.6]}\end{array}$ & $\begin{array}{r}566.7 \\
{[3,717.1]}\end{array}$ \\
\hline $\begin{array}{l}\text { Debt securities held by nonresidents } \\
\text { (percent of total) }\end{array}$ & $\begin{array}{r}3.2 \\
{[3.6]}\end{array}$ & {$[\ldots]$} & $\begin{array}{r}3.3 \\
{[4.0]}\end{array}$ & $\begin{array}{r}3.1 \\
{[3.3]}\end{array}$ & $\begin{array}{l}\text { Foreign currency long-term sovereign debt } \\
\text { ratings (index ranging from } 1 \text { to } 21 \text { [best]) }\end{array}$ & $\begin{array}{r}13.1 \\
{[5.2]}\end{array}$ & $\begin{array}{r}14.8 \\
{[4.8]}\end{array}$ & $\begin{array}{r}12.9 \\
{[5.3]}\end{array}$ & $\begin{array}{r}12.5 \\
{[5.1]}\end{array}$ \\
\hline $\begin{array}{l}\text { General government debt held by nonresidents } \\
\text { (percent of total) }\end{array}$ & $\begin{array}{r}40.7 \\
{[21.6}\end{array}$ & $\begin{array}{r}22.6 \\
{[10.1]}\end{array}$ & $\begin{array}{r}39.0 \\
{[21.5]}\end{array}$ & $\begin{array}{r}42.6 \\
{[21.7]}\end{array}$ & & & & & \\
\hline
\end{tabular}

Note: Simple averages. Standard deviations are presented in bracket. 1/ Only six data points are available in 1990s. 
Table 5. Descriptive statistics of fiscal space, advanced economies

\begin{tabular}{|c|c|c|c|c|c|c|c|c|c|}
\hline Advanced economies & Full period & $1990 \mathrm{~s}$ & $2000-07$ & 2008-16 & Advanced economies & Full period & $1990 \mathrm{~s}$ & $2000-07$ & $2008-16$ \\
\hline Government debt sustainability & & & & & Balance sheet composition (continued) & & & & \\
\hline $\begin{array}{l}\text { General government gross debt } \\
\text { (percent of GDP) }\end{array}$ & $\begin{array}{r}58.4 \\
{[38.1]}\end{array}$ & $\begin{array}{r}57.1 \\
{[30.6]}\end{array}$ & $\begin{array}{r}50.2 \\
{[34.3]}\end{array}$ & $\begin{array}{r}66.5 \\
{[44.5]}\end{array}$ & $\begin{array}{l}\text { Concessional external debt stocks } \\
\text { (percent of general government gross debt) }\end{array}$ & $\begin{array}{c}\cdots \\
{[\ldots]}\end{array}$ & $\begin{array}{c}\cdots \\
{[\ldots]}\end{array}$ & $\begin{array}{c}\ldots \\
{[\ldots]}\end{array}$ & $\begin{array}{c}\cdots \\
{[\ldots]}\end{array}\left[\begin{array}{l}n \\
{[\ldots]}\end{array}\right]$ \\
\hline $\begin{array}{l}\text { Primary balance } \\
\text { (percent of GDP) }\end{array}$ & $\begin{array}{r}0.1 \\
{[4.0]}\end{array}$ & $\begin{array}{r}0.6 \\
{[4.2]}\end{array}$ & $\begin{array}{r}1.2 \\
{[3.3]}\end{array}$ & $\begin{array}{r}-1.2 \\
{[4.0]}\end{array}$ & $\begin{array}{l}\text { Sovereign debt average maturity } \\
\quad \text { (years) } 1 /\end{array}$ & $\begin{array}{r}7.4 \\
{[2.3]}\end{array}$ & $\begin{array}{r}7.2 \\
{[1.5]}\end{array}$ & $\begin{array}{r}7.1 \\
{[1.9]}\end{array}$ & $\begin{array}{r}7.6 \\
{[2.5]}\end{array}$ \\
\hline $\begin{array}{l}\text { Cyclically-adjusted balance } \\
\text { (percent of potential GDP) }\end{array}$ & $\begin{array}{r}-1.7 \\
{[4.5]}\end{array}$ & $\begin{array}{r}-2.0 \\
{[4.8]}\end{array}$ & $\begin{array}{r}-0.9 \\
{[4.0]}\end{array}$ & $\begin{array}{r}-2.1 \\
{[4.6]}\end{array}$ & $\begin{array}{l}\text { Central government debt maturing in } \\
12 \text { months or less (percent of GDP) }\end{array}$ & $\begin{array}{l}11.0 \\
{[9.8]}\end{array}$ & $\begin{array}{c}\cdots \\
{[\ldots]}\end{array}$ & $\begin{array}{c}\cdots \\
{[\ldots]}\end{array}$ & $\begin{array}{l}11.0 \\
{[9.8]}\end{array}$ \\
\hline $\begin{array}{l}\text { Fiscal balance } \\
\quad \text { (percent of GDP) }\end{array}$ & $\begin{array}{r}-1.5 \\
{[5.2]}\end{array}$ & $\begin{array}{r}-2.3 \\
{[4.9]}\end{array}$ & $\begin{array}{r}-0.2 \\
{[4.3]}\end{array}$ & $\begin{array}{r}-1.9 \\
{[5.8]}\end{array}$ & External and private sector debt & & & & \\
\hline $\begin{array}{l}\text { General government gross debt } \\
\text { (percent of average tax revenues) }\end{array}$ & $\begin{array}{r}251.9 \\
{[199.5]}\end{array}$ & $\begin{array}{r}234.4 \\
{[140.4]}\end{array}$ & $\begin{array}{r}218.9 \\
{[183.5]}\end{array}$ & $\begin{array}{r}294.7 \\
{[242.2]}\end{array}$ & $\begin{array}{l}\text { Total external debt stocks } \\
\text { (percent of GDP) }\end{array}$ & $\begin{array}{r}326.2 \\
{[750.8]}\end{array}$ & $\begin{array}{r}81.6 \\
{[48.0]}\end{array}$ & $\begin{array}{r}258.0 \\
{[580.4]}\end{array}$ & $\begin{array}{r}381.5 \\
{[853.2]}\end{array}$ \\
\hline $\begin{array}{l}\text { Fiscal balance } \\
\text { (percent of average tax revenues) }\end{array}$ & $\begin{array}{r}-6.2 \\
{[23.8]}\end{array}$ & $\begin{array}{r}-7.8 \\
{[26.7]}\end{array}$ & $\begin{array}{r}-1.9 \\
{[19.0}\end{array}$ & $\begin{array}{r}-8.5 \\
{[24.7]}\end{array}$ & $\begin{array}{l}\text { External debt in foreign currency } \\
\text { (percent of total) } 1 /\end{array}$ & $\begin{array}{r}51.2 \\
{[31.5]}\end{array}$ & $\begin{array}{r}90.0 \\
{[14.5]}\end{array}$ & $\begin{array}{r}68.9 \\
{[30.6]}\end{array}$ & $\begin{array}{r}42.3 \\
{[28.1]}\end{array}$ \\
\hline $\begin{array}{l}\text { Sustainability gap, fiscal balance } \\
\text { (percent of GDP) }\end{array}$ & $\begin{array}{r}1.0 \\
{[6.5]}\end{array}$ & $\begin{array}{r}0.9 \\
{[5.8]}\end{array}$ & $\begin{array}{r}3.2 \\
{[5.5]}\end{array}$ & $\begin{array}{r}-0.7 \\
{[7.3]}\end{array}$ & $\begin{array}{l}\text { Private external debt stocks } \\
\quad \text { (percent of GDP) }\end{array}$ & $\begin{array}{r}293.8 \\
{[745.1]}\end{array}$ & $\begin{array}{r}65.9 \\
{[49.3]}\end{array}$ & $\begin{array}{r}236.6 \\
{[582.9]}\end{array}$ & $\begin{array}{r}341.2 \\
{[844.9]}\end{array}$ \\
\hline $\begin{array}{l}\text { Sustainability gap, primary balance, country- } \\
\text { specific conditions (percent of GDP) }\end{array}$ & $\begin{array}{r}0.2 \\
{[4.1]}\end{array}$ & $\begin{array}{r}0.6 \\
{[4.4]}\end{array}$ & $\begin{array}{r}1.3 \\
{[3.4]}\end{array}$ & $\begin{array}{r}-1.1 \\
{[4.1]}\end{array}$ & $\begin{array}{l}\text { Domestic credit to private sector } \\
\quad \text { (percent of GDP) }\end{array}$ & $\begin{array}{r}96.6 \\
{[46.2]}\end{array}$ & $\begin{array}{r}79.4 \\
{[38.2]}\end{array}$ & $\begin{array}{r}96.1 \\
{[45.7]}\end{array}$ & $\begin{array}{r}114.9 \\
{[47.4]}\end{array}$ \\
\hline $\begin{array}{l}\text { Sustainability gap, primary balance, historical } \\
\text { conditions (percent of GDP) }\end{array}$ & $\begin{array}{r}0.4 \\
{[4.1]}\end{array}$ & $\begin{array}{r}0.7 \\
{[4.3]}\end{array}$ & $\begin{array}{r}1.5 \\
{[3.4]}\end{array}$ & $\begin{array}{r}-0.9 \\
{[4.1]}\end{array}$ & $\begin{array}{l}\text { Short-term external debt stocks } \\
\text { (percent of total) }\end{array}$ & $\begin{array}{r}40.8 \\
{[16.5]}\end{array}$ & $\begin{array}{r}37.9 \\
{[17.9]}\end{array}$ & $\begin{array}{r}42.5 \\
{[17.7]}\end{array}$ & $\begin{array}{r}39.9 \\
{[15.6]}\end{array}$ \\
\hline $\begin{array}{l}\text { Sustainability gap, primary balance, current } \\
\text { conditions (percent of GDP) }\end{array}$ & $\begin{array}{r}-0.1 \\
{[5.4]}\end{array}$ & $\begin{array}{r}-0.7 \\
{[4.5]}\end{array}$ & $\begin{array}{r}2.3 \\
{[4.2]}\end{array}$ & $\begin{array}{r}-1.8 \\
{[6.1]}\end{array}$ & $\begin{array}{l}\text { Short-term external debt stocks } \\
\text { (percent of reserves) }\end{array}$ & $\begin{array}{r}7,898.5 \\
{[39,278.9]}\end{array}$ & $\begin{array}{r}637.1 \\
{[1,504.9]}\end{array}$ & $\begin{array}{r}11,329.6 \\
{[55,473.8]}\end{array}$ & $\begin{array}{r}6,059.2 \\
{[25,133.2]}\end{array}$ \\
\hline $\begin{array}{l}\text { Sustainability gap, primary balance, stressed } \\
\text { conditions (percent of GDP) }\end{array}$ & $\begin{array}{r}-3.1 \\
{[4.3]}\end{array}$ & $\begin{array}{r}-2.7 \\
{[4.4]}\end{array}$ & $\begin{array}{r}-2.1 \\
{[3.7]}\end{array}$ & $\begin{array}{r}-4.4 \\
{[4.3]}\end{array}$ & $\begin{array}{l}\text { Total external debt stocks } \\
\text { (percent of reserves) }\end{array}$ & $\begin{array}{r}18,563.4 \\
{[79,033.2]}\end{array}$ & $\begin{array}{r}1,210.2 \\
{[1,910.6]}\end{array}$ & $\begin{array}{r}21,566.1 \\
{[99,097.8]}\end{array}$ & $\begin{array}{r}17,482.6 \\
{[65,348.9]}\end{array}$ \\
\hline $\begin{array}{l}\text { Sustainability gap, primary balance, benign } \\
\text { conditions (percent of GDP) }\end{array}$ & $\begin{array}{r}2.3 \\
{[4.2]}\end{array}$ & $\begin{array}{r}2.6 \\
{[4.4]}\end{array}$ & $\begin{array}{r}3.4 \\
{[3.4]}\end{array}$ & $\begin{array}{r}1.0 \\
{[4.2]}\end{array}$ & $\begin{array}{l}\text { Total external debt stocks } \\
\text { (percent of reserves excluding gold) }\end{array}$ & $\begin{array}{r}24,579.6 \\
{[98,018.7]}\end{array}$ & $\begin{array}{r}1,424.9 \\
{[2,251.9]}\end{array}$ & $\begin{array}{r}28,601.6 \\
129,324.5]\end{array}$ & $\begin{array}{r}23,127.5 \\
{[74,378.9]}\end{array}$ \\
\hline Balance sheet composition & & & & & Market perception & & & & \\
\hline $\begin{array}{l}\text { General government debt in foreign currency } \\
\text { (percent of total) }\end{array}$ & $\begin{array}{r}7.4 \\
{[14.7]}\end{array}$ & $\begin{array}{r}8.6 \\
{[11.4]}\end{array}$ & $\begin{array}{r}6.6 \\
{[13.1]}\end{array}$ & $\begin{array}{r}7.7 \\
{[16.5]}\end{array}$ & $\begin{array}{l}\text { 5-year sovereign CDS spreads } \\
\text { (basis points) } 1 /\end{array}$ & $\begin{array}{r}257.5 \\
{[2,725.8]}\end{array}$ & $\begin{array}{r}190.4 \\
{[222.6]}\end{array}$ & $\begin{array}{r}13.7 \\
{[21.0]}\end{array}$ & $\begin{array}{r}346.5 \\
{[3,201.2]}\end{array}$ \\
\hline $\begin{array}{l}\text { Debt securities held by nonresidents } \\
\text { (percent of total) }\end{array}$ & $\begin{array}{r}3.9 \\
{[3.8}\end{array}$ & $\begin{array}{c}\cdots \\
{[\ldots]}\end{array}$ & $\begin{array}{r}4.1 \\
{[4.3]}\end{array}$ & $\begin{array}{r}3.8 \\
{[3.4]}\end{array}$ & $\begin{array}{l}\text { Foreign currency long-term sovereign debt } \\
\text { ratings (index ranging from } 1 \text { to } 21 \text { [best]) }\end{array}$ & $\begin{array}{r}18.4 \\
{[3.1]}\end{array}$ & $\begin{array}{r}18.4 \\
{[2.9]}\end{array}$ & $\begin{array}{r}18.7 \\
{[2.6}\end{array}$ & $\begin{array}{r}18.0 \\
{[3.7]}\end{array}$ \\
\hline $\begin{array}{l}\text { General government debt held by nonresidents } \\
\text { (percent of total) }\end{array}$ & $\begin{array}{r}39.7 \\
{[20.8]}\end{array}$ & $\begin{array}{r}24.3 \\
{[9.4]}\end{array}$ & $\begin{array}{r}38.2 \\
{[20.4]}\end{array}$ & $\begin{array}{r}42.7 \\
{[21.2]}\end{array}$ & & & & & \\
\hline
\end{tabular}

Note: Simple averages. Standard deviations are presented in bracket. 1/ Less than 10 data points are available in 1990s. 
Table 6. Descriptive statistics of fiscal space, EMDEs

\begin{tabular}{|c|c|c|c|c|c|c|c|c|c|}
\hline EMDEs & Full period & 1990s & 2000-07 & $2008-16$ & EMDEs & Full period & $1990 \mathrm{~s}$ & $2000-07$ & $2008-16$ \\
\hline Government debt sustainability & & & & & Balance sheet composition (continued) & & & & \\
\hline $\begin{array}{l}\text { General government gross debt } \\
\text { (percent of GDP) }\end{array}$ & $\begin{array}{r}57.9 \\
{[52.4]}\end{array}$ & $\begin{array}{r}65.6 \\
{[47.2]}\end{array}$ & $\begin{array}{r}68.6 \\
{[69.9]}\end{array}$ & $\begin{array}{r}45.6 \\
{[30.5]}\end{array}$ & $\begin{array}{l}\text { Concessional external debt stocks } \\
\text { (percent of general government gross debt) }\end{array}$ & $\begin{array}{r}37.1 \\
{[26.7]}\end{array}$ & $\begin{array}{r}38.5 \\
{[25.3]}\end{array}$ & $\begin{array}{r}39.8 \\
{[27.7]}\end{array}$ & $\begin{array}{r}33.9 \\
{[26.1]}\end{array}$ \\
\hline $\begin{array}{l}\text { Primary balance } \\
\quad \text { (percent of GDP) }\end{array}$ & $\begin{array}{r}-0.9 \\
{[14.8]}\end{array}$ & $\begin{array}{r}-2.8 \\
{[26.1]}\end{array}$ & $\begin{array}{r}0.8 \\
{[7.3]}\end{array}$ & $\begin{array}{r}-1.2 \\
{[6.6]}\end{array}$ & $\begin{array}{l}\text { Sovereign debt average maturity } \\
\text { (years) }\end{array}$ & $\begin{array}{r}10.2 \\
{[5.1]}\end{array}$ & $\begin{array}{r}12.9 \\
{[5.5]}\end{array}$ & $\begin{array}{r}10.2 \\
{[5.4]}\end{array}$ & $\begin{array}{r}9.6 \\
{[4.7]}\end{array}$ \\
\hline $\begin{array}{l}\text { Cyclically-adjusted balance } \\
\text { (percent of potential GDP) }\end{array}$ & $\begin{array}{r}-2.8 \\
{[13.5]}\end{array}$ & $\begin{array}{r}-4.8 \\
{[23.7]}\end{array}$ & $\begin{array}{r}-1.2 \\
{[6.3]}\end{array}$ & $\begin{array}{r}-2.7 \\
{[5.4]}\end{array}$ & $\begin{array}{l}\text { Central government debt maturing in } \\
12 \text { months or less (percent of GDP) }\end{array}$ & $\begin{array}{r}5.2 \\
{[6.1]}\end{array}$ & $\begin{array}{r}\ldots \\
{[\ldots]}\end{array}$ & {$[\ldots$} & $\begin{array}{r}5.2 \\
{[6.1]}\end{array}$ \\
\hline $\begin{array}{l}\text { Fiscal balance } \\
\quad \text { (percent of GDP) }\end{array}$ & $\begin{array}{r}-2.6 \\
{[14.9]}\end{array}$ & $\begin{array}{r}-5.0 \\
{[25.6]}\end{array}$ & $\begin{array}{r}-1.0 \\
{[8.0]}\end{array}$ & $\begin{array}{r}-2.4 \\
{[7.5]}\end{array}$ & External and private sector debt & & & & \\
\hline $\begin{array}{l}\text { General government gross debt } \\
\text { (percent of average tax revenues) }\end{array}$ & $\begin{array}{r}568.0 \\
{[1,318.0]}\end{array}$ & $\begin{array}{r}746.7 \\
{[1,505.1]}\end{array}$ & $\begin{array}{r}683.1 \\
{[1,732.1]}\end{array}$ & $\begin{array}{r}390.5 \\
{[614.3]}\end{array}$ & $\begin{array}{l}\text { Total external debt stocks } \\
\text { (percent of GDP) }\end{array}$ & $\begin{array}{r}61.8 \\
{[69.0]}\end{array}$ & $\begin{array}{r}74.6 \\
{[92.0]}\end{array}$ & $\begin{array}{r}64.9 \\
{[64.1]}\end{array}$ & $\begin{array}{r}46.2 \\
{[35.2]}\end{array}$ \\
\hline $\begin{array}{l}\text { Fiscal balance } \\
\text { (percent of average tax revenues) }\end{array}$ & $\begin{array}{r}-10.9 \\
{[409.2]}\end{array}$ & $\begin{array}{r}-70.9 \\
{[603.5]}\end{array}$ & $\begin{array}{r}21.5 \\
{[308.7]}\end{array}$ & $\begin{array}{r}2.7 \\
{[300.1]}\end{array}$ & $\begin{array}{l}\text { External debt in foreign currency } \\
\text { (percent of total) } 1 /\end{array}$ & $\begin{array}{r}89.6 \\
{[12.6]}\end{array}$ & $\begin{array}{r}100.0 \\
{[0.0]}\end{array}$ & $\begin{array}{r}91.7 \\
{[11.8]}\end{array}$ & $\begin{array}{r}88.6 \\
{[12.9]}\end{array}$ \\
\hline $\begin{array}{l}\text { Sustainability gap, fiscal balance } \\
\text { (percent of GDP) }\end{array}$ & $\begin{array}{r}1.4 \\
{[16.1]}\end{array}$ & $\begin{array}{r}-0.5 \\
{[26.5]}\end{array}$ & $\begin{array}{r}3.9 \\
{[9.6]}\end{array}$ & $\begin{array}{r}0.5 \\
{[9.6]}\end{array}$ & $\begin{array}{l}\text { Private external debt stocks } \\
\quad \text { (percent of GDP) }\end{array}$ & $\begin{array}{r}12.7 \\
{[22.6]}\end{array}$ & $\begin{array}{r}8.8 \\
{[17.6]}\end{array}$ & $\begin{array}{r}11.3 \\
{[18.1]}\end{array}$ & $\begin{array}{r}17.9 \\
{[28.9]}\end{array}$ \\
\hline $\begin{array}{l}\text { Sustainability gap, primary balance, country- } \\
\text { specific conditions (percent of GDP) }\end{array}$ & $\begin{array}{r}0.1 \\
{[4.8]}\end{array}$ & $\begin{array}{r}0.5 \\
{[4.4]}\end{array}$ & $\begin{array}{r}1.2 \\
{[5.1]}\end{array}$ & $\begin{array}{r}-1.0 \\
{[4.6]}\end{array}$ & $\begin{array}{l}\text { Domestic credit to private sector } \\
\quad \text { (percent of GDP) }\end{array}$ & $\begin{array}{r}30.4 \\
{[25.1]}\end{array}$ & $\begin{array}{r}24.4 \\
{[22.9]}\end{array}$ & $\begin{array}{r}28.0 \\
{[23.4]}\end{array}$ & $\begin{array}{r}38.4 \\
{[26.6]}\end{array}$ \\
\hline $\begin{array}{l}\text { Sustainability gap, primary balance, historical } \\
\text { conditions (percent of GDP) }\end{array}$ & $\begin{array}{r}0.4 \\
{[4.8]}\end{array}$ & $\begin{array}{r}0.7 \\
{[4.3]}\end{array}$ & $\begin{array}{r}1.5 \\
{[5.1]}\end{array}$ & $\begin{array}{r}-0.8 \\
{[4.6]}\end{array}$ & $\begin{array}{l}\text { Short-term external debt stocks } \\
\quad \text { (percent of total) }\end{array}$ & $\begin{array}{r}12.3 \\
{[12.5]}\end{array}$ & $\begin{array}{r}11.6 \\
{[13.0]}\end{array}$ & $\begin{array}{r}12.1 \\
{[12.1]}\end{array}$ & $\begin{array}{r}13.1 \\
{[12.5]}\end{array}$ \\
\hline $\begin{array}{l}\text { Sustainability gap, primary balance, current } \\
\text { conditions (percent of GDP) }\end{array}$ & $\begin{array}{r}0.0 \\
{[6.8]}\end{array}$ & $\begin{array}{r}-0.5 \\
{[6.8]}\end{array}$ & $\begin{array}{r}1.8 \\
{[7.0]}\end{array}$ & $\begin{array}{r}-1.2 \\
{[6.4]}\end{array}$ & $\begin{array}{l}\text { Short-term external debt stocks } \\
\quad \text { (percent of reserves) }\end{array}$ & $\begin{array}{r}923.1 \\
{[14,704.6]}\end{array}$ & $\begin{array}{r}1,607.8 \\
{[15,775.1]}\end{array}$ & $\begin{array}{r}1,123.2 \\
{[20,521.3]}\end{array}$ & $\begin{array}{r}64.2 \\
{[236.7]}\end{array}$ \\
\hline $\begin{array}{l}\text { Sustainability gap, primary balance, stressed } \\
\text { conditions (percent of GDP) }\end{array}$ & $\begin{array}{r}-5.6 \\
{[5.7]}\end{array}$ & $\begin{array}{r}-4.7 \\
{[4.9]}\end{array}$ & $\begin{array}{r}-4.7 \\
{[5.6}\end{array}$ & $\begin{array}{r}-7.0 \\
{[6.0]}\end{array}$ & $\begin{array}{l}\text { Total external debt stocks } \\
\text { (percent of reserves) }\end{array}$ & $\begin{array}{r}2,977.7 \\
{[31,595.7]}\end{array}$ & $\begin{array}{r}5,775.1 \\
{[37,910.9]}\end{array}$ & $\begin{array}{r}2,764.6 \\
{[40,172.7]}\end{array}$ & $\begin{array}{r}391.3 \\
{[986.4]}\end{array}$ \\
\hline $\begin{array}{l}\text { Sustainability gap, primary balance, benign } \\
\text { conditions (percent of GDP) }\end{array}$ & $\begin{array}{r}2.8 \\
{[5.7]}\end{array}$ & $\begin{array}{r}2.8 \\
{[5.0]}\end{array}$ & $\begin{array}{r}4.0 \\
{[6.1]}\end{array}$ & $\begin{array}{r}1.8 \\
{[5.6]}\end{array}$ & $\begin{array}{l}\text { Total external debt stocks } \\
\text { (percent of reserves excluding gold) }\end{array}$ & $\begin{array}{r}5,078.9 \\
{[49,804.9]}\end{array}$ & $\begin{array}{r}11,785.8 \\
{[75,414.2]}\end{array}$ & $\begin{array}{r}2,822.9 \\
{[40,180.3]}\end{array}$ & $\begin{array}{r}428.6 \\
{[1,034.6]}\end{array}$ \\
\hline Balance sheet composition & & & & & Market perception & & & & \\
\hline $\begin{array}{l}\text { General government debt in foreign currency } \\
\text { (percent of total) } 1 /\end{array}$ & $\begin{array}{r}50.2 \\
{[26.1]}\end{array}$ & $\begin{array}{r}26.2 \\
{[17.6]}\end{array}$ & $\begin{array}{r}46.4 \\
{[34.4]}\end{array}$ & $\begin{array}{r}51.1 \\
{[25.3]}\end{array}$ & $\begin{array}{l}\text { 5-year sovereign CDS spreads } \\
\text { (basis points) }\end{array}$ & $\begin{array}{r}585.0 \\
{[3,092.2]}\end{array}$ & $\begin{array}{r}903.7 \\
{[1,565.8]}\end{array}$ & $\begin{array}{r}272.4 \\
{[336.0]}\end{array}$ & $\begin{array}{r}739.4 \\
{[4,072.7]}\end{array}$ \\
\hline $\begin{array}{l}\text { Debt securities held by nonresidents } \\
\text { (percent of total) }\end{array}$ & $\begin{array}{r}1.0 \\
{[1.3]}\end{array}$ & $\left.\begin{array}{c}\cdots \\
{[\ldots]}\end{array}\right]$ & $\begin{array}{r}0.7 \\
{[0.8]}\end{array}$ & $\begin{array}{r}1.2 \\
{[1.5]}\end{array}$ & $\begin{array}{l}\text { Foreign currency long-term sovereign debt } \\
\text { ratings (index ranging from } 1 \text { to } 21 \text { [best]) }\end{array}$ & $\begin{array}{r}10.2 \\
{[3.6}\end{array}$ & $\begin{array}{r}10.8 \\
{[2.9]}\end{array}$ & $\begin{array}{r}10.0 \\
{[3.6]}\end{array}$ & $\begin{array}{r}10.2 \\
{[3.8]}\end{array}$ \\
\hline $\begin{array}{l}\text { General government debt held by nonresidents } \\
\text { (percent of total) } 1 /\end{array}$ & $\begin{array}{r}41.7 \\
{[22.4]}\end{array}$ & $\begin{array}{r}10.4 \\
{[5.6}\end{array}$ & $\begin{array}{r}40.2 \\
{[23.3]}\end{array}$ & $\begin{array}{r}42.6 \\
{[22.0]}\end{array}$ & & & & & \\
\hline
\end{tabular}

Note: Simple averages. Standard deviations are presented in bracket. 1/ Less than 10 data points are available in 1990s. 


\title{
SUPPLEMENTARY APPENDIX
}

\section{A Cross-Country Database of Fiscal Space}

\author{
M. Ayhan Kose, Sergio Kurlat, Franziska Ohnsorge, and Naotaka Sugawara*
}

August 2017

\section{This appendix contains:}

Table A1. $\quad$ Select studies on fiscal databases

Table A2. Derivation of nominal long-term interest rate

Table A3. Correlation coefficients among indicators of fiscal space for all countries (A), advanced economies (B) and emerging market and developing economies (EMDEs) (C).

Table A4. Volatility of fiscal space indicators

Table A5. Changes in fiscal space, share of countries, all countries

Table A6. Changes in fiscal space, share of countries, advanced economies

Table A7. Changes in fiscal space, share of countries, EMDEs

Table A8. $\quad$ List of crisis episodes

Table A9. Changes in fiscal space during financial crises, before vs after

Table A10. Changes in fiscal space, pre-crisis vs current period

Table A11. Changes in fiscal space over oil price plunges

\footnotetext{
* Kose (Development Prospects Group, World Bank; Brookings Institution; CEPR; CAMA; akose@worldbank.org); Ohnsorge (Development Prospects Group, World Bank; CAMA; fohnsorge@worldbank.org); Sugawara (Development Prospects Group, World Bank; nsugawara@worldbank.org). Kurlat was a consultant at the Development Prospects Group when the early analysis was conducted for this study. We would like to thank Carlos Arteta, Eduardo Borenzstein, Kevin Clinton, Raphael Espinoza, Raju Huidrom, Anna Ivanova, Ugo Panizza, Evis Rucaj, Marc Stocker, Carlos Végh, Dana Vorisek and seminar participants at the World Bank for valuable comments, and Graeme Littler and Praveen Penmetsa for developing the database web interface. Xinghao Gong provided excellent research assistance. The findings, interpretations and conclusions expressed in this paper are entirely those of the authors and should not be attributed to the World Bank, its Executive Directors, or the countries they represent. The database is available at: http://www.worldbank.org/en/research/brief/fiscal-space.
} 
Table A1. Select studies on fiscal databases

\begin{tabular}{|c|c|c|c|}
\hline & \multicolumn{2}{|c|}{ Coverage } & \multirow[b]{2}{*}{ Indicators of fiscal space } \\
\hline & Country & Period & \\
\hline $\begin{array}{l}\text { Abbas et al. }(2011) \\
\text { [Fall } 2013 \text { version] }\end{array}$ & $178 \mathrm{AE} / \mathrm{EMDE}$ & $1692-2012$ & Central/General government debt \\
\hline Abbas and Christensen (2010) & 93 LIC/EM & 1975-2004 & Central government domestic debt \\
\hline $\begin{array}{l}\text { Arslanalp and Tsuda (2014a) } \\
\text { [April } 2017 \text { version] }\end{array}$ & $24 \mathrm{AE}$ & 2004Q1-2016Q4 & General government debt 1 / \\
\hline $\begin{array}{l}\text { Arslanalp and Tsuda (2014b) } \\
\text { [April } 2017 \text { version] }\end{array}$ & $24 \mathrm{EM}$ & 2004Q1-2016Q4 & General government debt $1 /$ \\
\hline Bova et al. (2016) & $\begin{array}{l}34 \mathrm{AE} \\
46 \mathrm{EM}\end{array}$ & $1990-2014$ & Contingent liability realizations \\
\hline Bua, Pradelli, and Presbitero (2014) & $40 \mathrm{LIC} / \mathrm{LMC}$ & 1971-2011 & Central government debt $1 /$ \\
\hline Ilzetzki, Mendoza, and Végh (2013) & $\begin{array}{l}20 \mathrm{AE} \\
24 \mathrm{EMDE}\end{array}$ & 1960Q1-2007Q4 & $\begin{array}{l}\text { Government consumption; } \\
\text { Government investment }\end{array}$ \\
\hline Cowan et al. (2006) & $30 \mathrm{AE} / \mathrm{EMDE}$ & 1980-2006 & Central government debt $1 /$ \\
\hline Jaimovich and Panizza (2010) & $140 \mathrm{AE} / \mathrm{EMDE}$ & $1970-2005$ & Central government debt \\
\hline Jeanne and Guscina (2006) & $19 \mathrm{EM}$ & $1980-2002$ & Central government debt $1 /$ \\
\hline Mansour (2014) & 41 Africa & $1980-2010$ & Tax revenues $1 /$ \\
\hline Mauro et al. (2015) & $\begin{array}{l}24 \mathrm{AE} \\
31 \mathrm{EMDE}\end{array}$ & $1800-2011$ & $\begin{array}{l}\text { Government debt; Revenues; } \\
\text { Expenditure; Primary balance }\end{array}$ \\
\hline Panizza (2008) & 130 AE/EMDE & 1990-2007 & Central/General government debt \\
\hline $\begin{array}{l}\text { Prichard, Cobham, and Goodall (2014) } \\
\text { [May } 2016 \text { update] }\end{array}$ & 204 AE/EMDE & $1980-2013$ & Central/General government revenues $1 /$ \\
\hline Reinhart and Rogoff (2011) & 64 AE/EMDE & $1791-2010$ & Revenues; Central government debt 1 / \\
\hline
\end{tabular}

Note: AE, EM, EMDE, LIC and LMC refer to advanced economies, emerging markets, emerging market and developing economies, low income countries and lower-middle income countries, respectively.

1/ The database contains detailed information (e.g., composition and structure) of fiscal indicators. 
Table A2. Derivation of nominal long-term interest rate

\begin{tabular}{ll}
\hline 10-year government bond yield & Australia; Austria; Bangladesh; Belgium; Botswana; Bulgaria; \\
& Canada; Cyprus; Czech Republic; Denmark; Estonia; Fiji; \\
& Finland; France; Germany; Greece; Hong Kong SAR, China; \\
& Hungary; Iceland; India; Indonesia; Ireland; Israel; Italy; \\
& Japan; Korea, Rep.; Latvia; Lithuania; Luxembourg; \\
& Malaysia; Malta; Morocco; Myanmar; Nepal; Netherlands; \\
& New Zealand; Norway; Portugal; Romania; Saudi Arabia; \\
& Singapore; Slovak Republic; Slovenia; South Africa; Spain; \\
& Sweden; Switzerland; Thailand; United Kingdom; United \\
& States; Vanuatu \\
\hline 10-year government bond yield, & Brazil; China; Colombia; Croatia; Egypt, Arab Rep.; Georgia; \\
extended by U.S. 10-year & Mexico; Pakistan; Peru; Philippines; Poland; Russian \\
government bond yield plus actual & Federation; Sri Lanka; Turkey; Ukraine; Vietnam \\
J.P. Morgan EMBI Global & \\
stripped spread (16) & \\
\hline U.S. 10-year government bond & Algeria; Argentina; Armenia; Belarus; Belize; Chile; Cote \\
yield plus actual J.P. Morgan & d'Ivoire; Dominican Republic; Ecuador; El Salvador; Gabon; \\
EMBI Global stripped spread (23) & Ghana; Iraq; Jamaica; Kazakhstan; Lebanon; Nigeria; \\
& Panama; Serbia; Trinidad \& Tobago; Tunisia; Uruguay; \\
\hline U.S. 10-year government bond & Venezuela, RB \\
\hline yield plus estimated J.P. Morgan & Angola; Azerbaijan; Bolivia; Cameroon; Costa Rica; Ethiopia; \\
EMBI Global stripped spread (17) & Mozambique; Namibia; Paraguay; Senegal; Tanzania; Zambia \\
\hline
\end{tabular}

Note: The number of countries is in parenthesis. The derivation of the nominal long-term interest rate differs across countries because of data constraints. First, it is proxied by the 10-year government bond yield for a group of 51 economies that have data available over a reasonably long period. Specifically, the 10-year bond yield is used for countries for which yield data have more observations than J.P. Morgan's EMBI Global Stripped Spread. Because of data availability, data on 5-year government bond yields are used in Fiji, Myanmar, and Nepal, and government bond yields for Estonia cover those over 5 years. Second, there are 16 countries with an insufficient number of observations; for them, the 10-year bond yield is extended using the sum of available U.S. government bond yields and EMBI spreads, since the stripped spread is the spread over U.S. Treasury bond stripped of its collateralized flows (Kim 2014). Finally, for those countries without any 10-year bond yield data, the long-term interest rate is proxied by the sum of the U.S. 10-year government bond yield and each country's EMBI Global Stripped Spread. The actual EMBI spread series is used for the 23 countries that have EMBI data over a long period. For 17 countries with limited availability of EMBI data, the spread is estimated as the predicted value from a fixed-effects linear regression of EMBI Global Stripped Spread on the Economist Intelligence Unit (EIU) country risk scores, using the EMDE sample. Predicted J.P. Morgan EMBI Global stripped spread is obtained in the following fixed-effects model: EMBI spread (in percent) $=-15.88+$ 0.413 [EIU country risk score] $+u+\varepsilon$, where $u$ and $\varepsilon$ are country fixed-effects and residuals, respectively. $R^{2}$ is 0.23 and both coefficients are found to be statistically significant at the 1 percent level. The estimation is based on 758 observations and 62 EMDEs where data are available over the period of 1997-2016. 
Table A3.A. Correlations among indicators of fiscal space, all countries

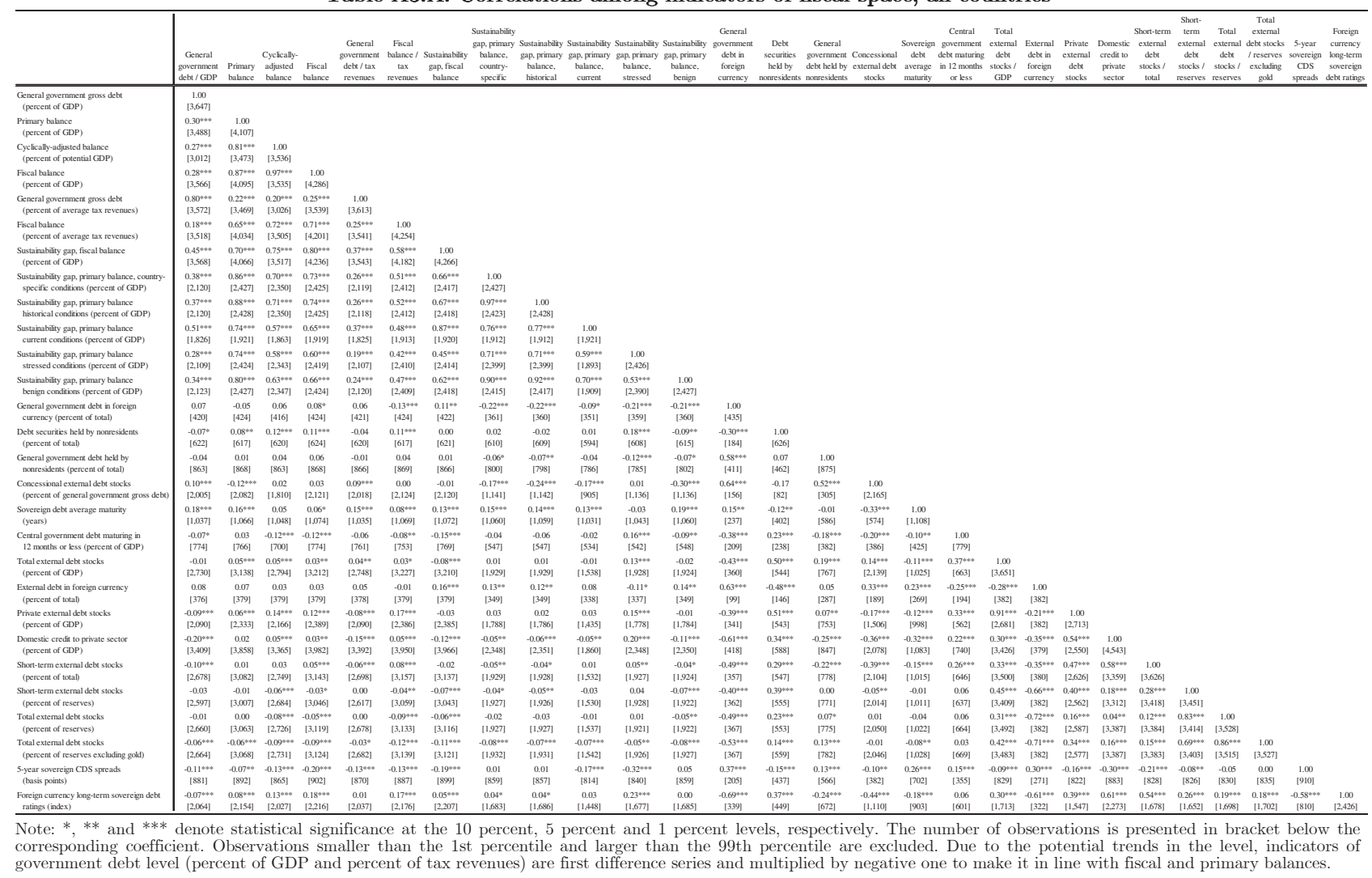


Table A3.B. Correlations among indicators of fiscal space, advanced economies

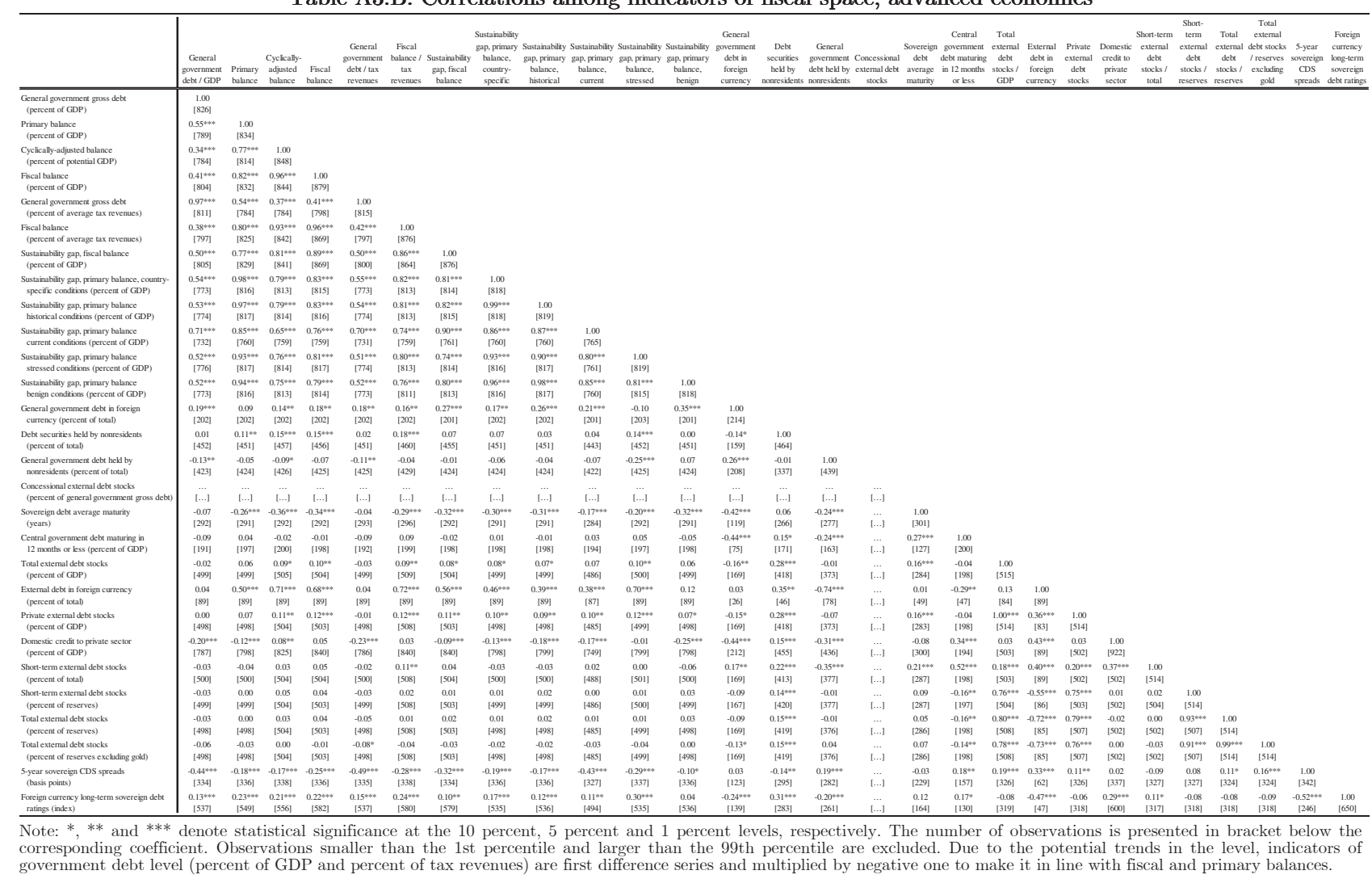


Table A3.C. Correlations among indicators of fiscal space, EMDEs

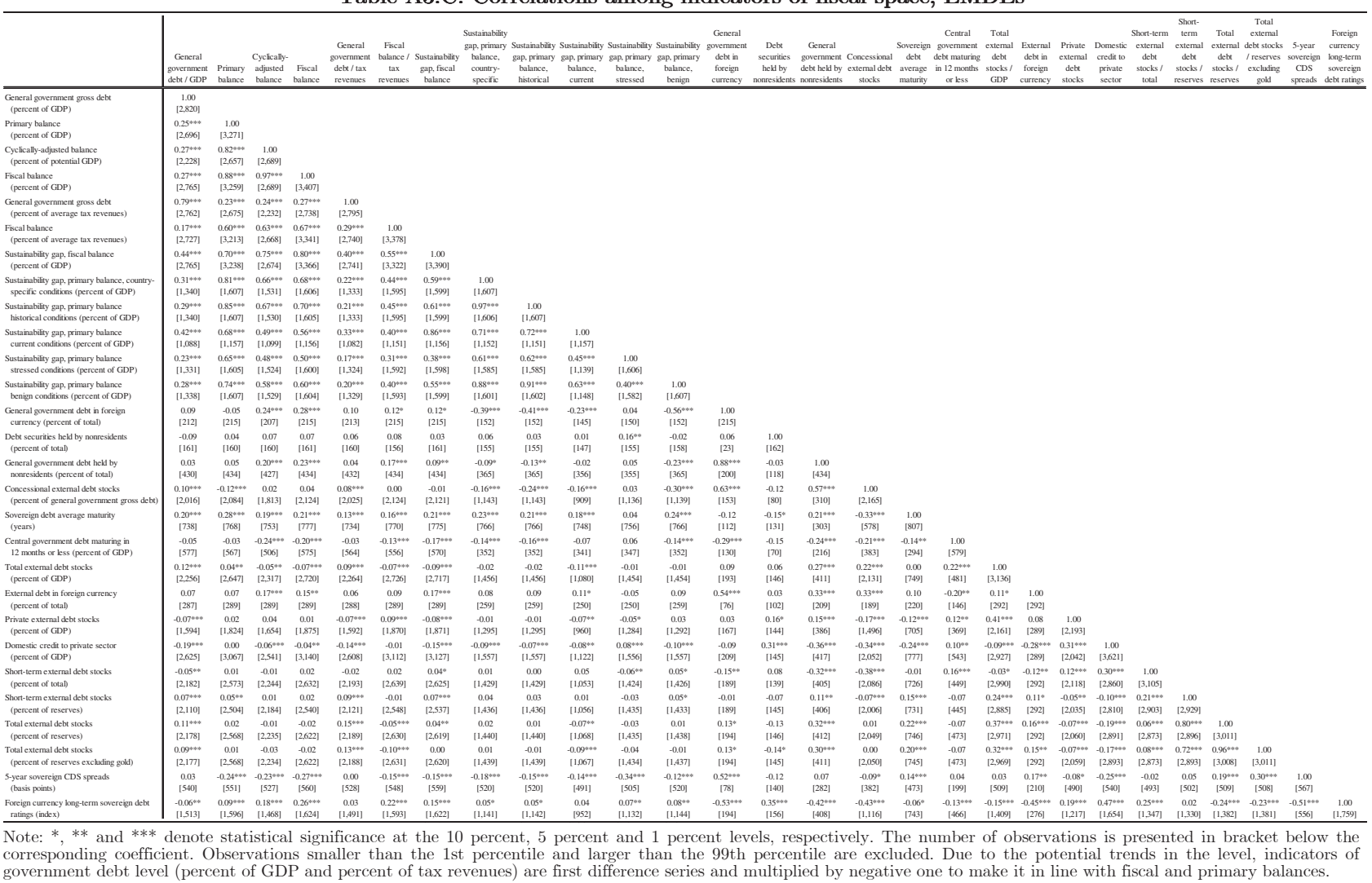


Table A4. Volatility of fiscal space indicators

\begin{tabular}{|c|c|c|c|c|c|c|}
\hline & \multicolumn{2}{|c|}{ All countries } & \multicolumn{2}{|c|}{ Advanced economies } & \multicolumn{2}{|c|}{ EMDEs } \\
\hline & $\begin{array}{l}\text { Cross- } \\
\text { Country }\end{array}$ & $\begin{array}{l}\text { Within- } \\
\text { Country }\end{array}$ & $\begin{array}{l}\text { Cross- } \\
\text { Country }\end{array}$ & $\begin{array}{l}\text { Within- } \\
\text { Country }\end{array}$ & $\begin{array}{l}\text { Cross- } \\
\text { Country }\end{array}$ & $\begin{array}{l}\text { Within- } \\
\text { Country }\end{array}$ \\
\hline \multicolumn{7}{|l|}{ Government debt sustainability } \\
\hline General government gross debt (percent of GDP) & 38.2 & 22.8 & 33.0 & 14.7 & 39.4 & 24.8 \\
\hline Primary balance (percent of GDP) & 5.0 & 4.9 & 2.3 & 2.8 & 5.5 & 5.4 \\
\hline Cyclically-adjusted balance (percent of potential GDP) & 4.8 & 4.3 & 3.3 & 2.7 & 5.2 & 4.7 \\
\hline Fiscal balance (percent of GDP) & 5.5 & 5.1 & 4.1 & 3.0 & 5.8 & 5.6 \\
\hline $\begin{array}{l}\text { General government gross debt } \\
\text { (percent of average tax revenues) }\end{array}$ & 982.3 & 277.4 & 174.7 & 65.7 & $1,082.9$ & 329.6 \\
\hline Fiscal balance (percent of average tax revenues) & 117.2 & 76.8 & 19.2 & 13.2 & 130.5 & 92.5 \\
\hline Sustainability gap, fiscal balance (percent of GDP) & 5.7 & 7.2 & 4.8 & 4.4 & 6.0 & 8.0 \\
\hline $\begin{array}{l}\text { Sustainability gap, primary balance } \\
\text { country-specific conditions (percent of GDP) }\end{array}$ & 2.9 & 3.1 & 2.4 & 2.9 & 3.1 & 3.2 \\
\hline $\begin{array}{l}\text { Sustainability gap, primary balance } \\
\text { historical conditions (percent of GDP) }\end{array}$ & 2.9 & 3.1 & 2.4 & 2.9 & 3.1 & 3.2 \\
\hline $\begin{array}{l}\text { Sustainability gap, primary balance } \\
\text { current conditions (percent of GDP) }\end{array}$ & 3.1 & 5.3 & 2.4 & 4.5 & 3.3 & 5.7 \\
\hline $\begin{array}{l}\text { Sustainability gap, primary balance } \\
\text { stressed conditions (percent of GDP) }\end{array}$ & 4.2 & 3.1 & 2.8 & 2.9 & 4.5 & 3.2 \\
\hline $\begin{array}{l}\text { Sustainability gap, primary balance } \\
\text { benign conditions (percent of GDP) }\end{array}$ & 4.0 & 3.1 & 2.6 & 2.9 & 4.5 & 3.2 \\
\hline \multicolumn{7}{|l|}{ Balance sheet composition } \\
\hline $\begin{array}{l}\text { General government debt in foreign currency } \\
\text { (percent of total) }\end{array}$ & 30.7 & 4.7 & 15.1 & 3.8 & 24.7 & 5.2 \\
\hline Debt securities held by nonresidents (percent of total) & 2.8 & 1.6 & 2.9 & 1.9 & 0.9 & 0.8 \\
\hline $\begin{array}{l}\text { General government debt held by nonresidents } \\
\text { (percent of total) }\end{array}$ & 21.2 & 6.5 & 19.6 & 7.4 & 22.1 & 5.9 \\
\hline $\begin{array}{l}\text { Concessional external debt stocks } \\
\text { (percent of general government gross debt) }\end{array}$ & 25.8 & 9.5 & $\ldots$ & $\ldots$ & 25.8 & 9.5 \\
\hline Sovereign debt average maturity (years) & 3.7 & 2.0 & 2.0 & 1.0 & 4.0 & 2.4 \\
\hline $\begin{array}{l}\text { Central government debt maturing in } \\
12 \text { months or less (percent of GDP) }\end{array}$ & 7.1 & 1.8 & 9.5 & 1.9 & 5.4 & 1.8 \\
\hline \multicolumn{7}{|l|}{ External and private sector debt } \\
\hline Total external debt stocks (percent of GDP) & 349.1 & 41.4 & 723.0 & 79.3 & 45.7 & 31.6 \\
\hline External debt in foreign currency (percent of total) & 27.3 & 3.3 & 25.9 & 4.1 & 11.7 & 2.9 \\
\hline Private external debt stocks (percent of GDP) & 348.3 & 20.4 & 720.4 & 71.5 & 25.5 & 7.1 \\
\hline Domestic credit to private sector (percent of GDP) & 36.7 & 12.5 & 37.6 & 22.2 & 21.8 & 10.1 \\
\hline Short-term external debt stocks (percent of total) & 15.6 & 6.8 & 14.5 & 6.8 & 9.2 & 6.9 \\
\hline Short-term external debt stocks (percent of reserves) & $16,508.7$ & $2,228.1$ & $32,271.0$ & $5,243.4$ & $7,294.6$ & $1,410.1$ \\
\hline Total external debt stocks (percent of reserves) & $36,494.2$ & $5,100.0$ & $71,384.0$ & $8,635.2$ & $16,011.8$ & $4,140.8$ \\
\hline $\begin{array}{l}\text { Total external debt stocks } \\
\text { (percent of reserves excluding gold) }\end{array}$ & $44,221.0$ & $10,285.6$ & $84,391.3$ & $13,785.8$ & $21,593.9$ & $9,336.0$ \\
\hline \multicolumn{7}{|l|}{ Market perception } \\
\hline 5-year sovereign CDS spreads (basis points) & $1,005.4$ & 692.4 & 643.8 & 506.7 & $1,190.6$ & 831.8 \\
\hline $\begin{array}{l}\text { Foreign currency long-term sovereign debt ratings } \\
\quad \text { (index ranging 1-21 [best]) }\end{array}$ & 4.9 & 1.1 & 2.6 & 1.3 & 3.2 & 1.0 \\
\hline
\end{tabular}

Note: Volatility is measured as standard deviation of respecitve variables in specified sample period and country group. Observations smaller than the 1st percentile and larger than the 99th percentile are excluded. 
Table A5. Changes in fiscal space, share of countries, all countries

\begin{tabular}{|c|c|c|c|c|c|c|c|c|}
\hline & \multicolumn{2}{|c|}{$1995-2016$} & \multicolumn{2}{|l|}{$2000-07$} & \multicolumn{2}{|c|}{$2000-16$} & \multicolumn{2}{|c|}{$2007-16$} \\
\hline & Share & & Share & & Share & & Share & \\
\hline & $\Delta-[\Delta+]$ & Obs. & $\Delta-[\Delta+]$ & Obs. & $\Delta-[\Delta+]$ & Obs. & $\Delta-[\Delta+]$ & Obs. \\
\hline \multicolumn{9}{|l|}{ Government debt sustainability } \\
\hline General government gross debt (percent of GDP) & $44.7[55.3]$ & 85 & $77.7[22.3]$ & 157 & $52.6[46.8]$ & 156 & 25.8 [74.2] & 182 \\
\hline Primary balance (percent of GDP) & $62.3[37.7]$ & 122 & $41.6[57.8]$ & 166 & $66.1[32.7]$ & 165 & $75.1[23.8]$ & 181 \\
\hline Cyclically-adjusted balance (percent of potential GDP) & $56.3[41.1]$ & 112 & $40.0[55.2]$ & 145 & $60.7[39.3]$ & 145 & $65.4[33.3]$ & 153 \\
\hline Fiscal balance (percent of GDP) & $52.3[45.3]$ & 128 & $31.0[66.1]$ & 174 & $60.1[38.7]$ & 173 & $75.9[21.4]$ & 187 \\
\hline $\begin{array}{l}\text { General government gross debt } \\
\quad \text { (percent of average tax revenues) }\end{array}$ & $44.7[55.3]$ & 85 & $77.7[22.3]$ & 157 & $53.2[46.8]$ & 156 & $26.1[73.9]$ & 180 \\
\hline Fiscal balance (percent of average tax revenues) & $53.1[46.9]$ & 128 & $32.2[67.8]$ & 174 & $61.3[38.7]$ & 173 & $78.0[21.5]$ & 186 \\
\hline Sustainability gap, fiscal balance (percent of GDP) & $77.6[22.4]$ & 125 & $23.7[75.7]$ & 169 & $63.7[34.5]$ & 168 & $89.3[10.7]$ & 187 \\
\hline $\begin{array}{l}\text { Sustainability gap, primary balance } \\
\text { country-specific conditions (percent of GDP) }\end{array}$ & $61.8[38.2]$ & 76 & $43.4[56.6]$ & 99 & 69.7 [29.3] & 99 & $78.5[21.5]$ & 107 \\
\hline $\begin{array}{l}\text { Sustainability gap, primary balance } \\
\text { historical conditions (percent of GDP) }\end{array}$ & 61.8 [38.2] & 76 & $43.4[56.6]$ & 99 & 69.7 [29.3] & 99 & 78.5 [21.5] & 107 \\
\hline $\begin{array}{l}\text { Sustainability gap, primary balance } \\
\text { current conditions (percent of GDP) }\end{array}$ & $38.7[61.3]$ & 31 & $29.2[69.4]$ & 72 & $57.7[39.4]$ & 71 & $87.1[10.9]$ & 101 \\
\hline $\begin{array}{l}\text { Sustainability gap, primary balance } \\
\text { stressed conditions (percent of GDP) }\end{array}$ & $61.8[38.2]$ & 76 & $43.4[56.6]$ & 99 & 69.7 [29.3] & 99 & $78.5[21.5]$ & 107 \\
\hline $\begin{array}{l}\text { Sustainability gap, primary balance } \\
\text { benign conditions (percent of GDP) }\end{array}$ & $61.8[38.2]$ & 76 & $43.4[56.6]$ & 99 & $69.7[29.3]$ & 99 & $78.5[21.5]$ & 107 \\
\hline \multicolumn{9}{|l|}{ Balance sheet composition } \\
\hline $\begin{array}{l}\text { General government debt in foreign currency } \\
\text { (percent of total) }\end{array}$ & $\ldots[\ldots]$ & 7 & $69.2[7.7]$ & 13 & 66.7 [25.0] & 12 & $40.0[40.0]$ & 15 \\
\hline Debt securities held by nonresidents (percent of total) & $\ldots[\ldots]$ & 0 & $\ldots[\ldots]$ & 0 & $\ldots[\ldots]$ & 0 & $51.2[39.0]$ & 41 \\
\hline $\begin{array}{l}\text { General government debt held by nonresidents } \\
\text { (percent of total) }\end{array}$ & $\ldots[\ldots]$ & 8 & $30.8[69.2]$ & 13 & 15.4 [84.6] & 13 & $45.1[54.9]$ & 51 \\
\hline $\begin{array}{l}\text { Concessional external debt stocks } \\
\text { (percent of general government gross debt) } 1 /\end{array}$ & $75.7[24.3]$ & 37 & $60.4[38.5]$ & 96 & $72.7[23.2]$ & 99 & 69.9 [29.2] & 113 \\
\hline Sovereign debt average maturity (years) & $90.0[10.0]$ & 10 & $54.5[45.5]$ & 22 & $47.8[52.2]$ & 23 & $48.3[51.7]$ & 58 \\
\hline $\begin{array}{l}\text { Central government debt maturing in } \\
12 \text { months or less (percent of GDP) 2/ }\end{array}$ & $\ldots[\ldots]$ & 0 & $\ldots[\ldots]$ & 0 & $\ldots[\ldots]$ & 0 & $32.5[62.4]$ & 117 \\
\hline \multicolumn{9}{|l|}{ External and private sector debt } \\
\hline Total external debt stocks (percent of GDP) & $50.9[49.1]$ & 55 & $70.5[29.5]$ & 129 & $44.8[55.2]$ & 67 & $34.0[66.0]$ & 94 \\
\hline External debt in foreign currency (percent of total) & $\ldots[\ldots]$ & 0 & $\ldots[\ldots]$ & 4 & $\ldots[\ldots]$ & 4 & $56.5[43.5]$ & 23 \\
\hline Private external debt stocks (percent of GDP) & $23.6[69.1]$ & 55 & $36.4[31.8]$ & 129 & $25.4[68.7]$ & 67 & $44.7[51.1]$ & 94 \\
\hline Domestic credit to private sector (percent of GDP) & $7.6[92.4]$ & 158 & $25.7[72.6]$ & 175 & $16.5[83.5]$ & 164 & $24.3[75.1]$ & 169 \\
\hline Short-term external debt stocks (percent of total) & $40.0[56.4]$ & 55 & $34.6[61.5]$ & 130 & $45.5[54.5]$ & 66 & $61.3[33.3]$ & 93 \\
\hline $\begin{array}{l}\text { Short-term external debt stocks } \\
\quad \text { (percent of reserves) }\end{array}$ & $55.6[44.4]$ & 54 & $62.9[33.9]$ & 124 & $62.1[36.4]$ & 66 & $59.1[38.7]$ & 93 \\
\hline Total external debt stocks (percent of reserves) & $74.5[25.5]$ & 55 & $78.2[21.8]$ & 124 & $77.6[22.4]$ & 67 & $46.8[53.2]$ & 94 \\
\hline $\begin{array}{l}\text { Total external debt stocks } \\
\quad \text { (percent of reserves excluding gold) }\end{array}$ & $74.5[25.5]$ & 55 & $78.2[21.8]$ & 124 & $74.6[25.4]$ & 67 & $45.7[54.3]$ & 94 \\
\hline \multicolumn{9}{|l|}{ Market perception } \\
\hline 5-year sovereign CDS spreads (basis points) & $\ldots[\ldots]$ & 0 & $93.3[0.0]$ & 15 & $66.7[33.3]$ & 15 & $1.9[98.1]$ & 53 \\
\hline $\begin{array}{l}\text { Foreign currency long-term sovereign debt ratings } \\
\quad \text { (index ranging } 1-21 \text { [best]) }\end{array}$ & $41.1[51.8]$ & 56 & $19.4[61.2]$ & 103 & $37.6[53.5]$ & 101 & $51.9[28.7]$ & 129 \\
\hline
\end{tabular}

Note: Share shows the percent shares of countries with negative change $\left(\Delta^{-}\right)$and with positive change $(\Delta+)$ (in bracket) over the denoted periods. The percent shares are not computed, when the number of observations is less than 10. A negative (positive) change refers to a change at least by 0.1 percenrage point for variables expressed in percent (or 10 basis points for CDS spreads). For sovereign debt average maturity and long-term sovereign debt ratings, a change by 0.1 percent is used. Because of small or no change in some indicators, they do not always add up to 100. 1/ Data for 2015 are used, instead of 2016. 2/ Data for 2011 are used, instead of 2007. 
Table A6. Changes in fiscal space, share of countries, advanced economies

\begin{tabular}{|c|c|c|c|c|c|c|c|c|}
\hline & \multicolumn{2}{|c|}{$1995-2016$} & \multicolumn{2}{|l|}{$2000-07$} & \multicolumn{2}{|l|}{$2000-16$} & \multicolumn{2}{|l|}{$2007-16$} \\
\hline & Share & & Share & & Share & & Share & \\
\hline & $\Delta-[\Delta+]$ & Obs. & $\Delta-[\Delta+]$ & Obs. & $\Delta-[\Delta+]$ & Obs. & $\Delta-[\Delta+]$ & Obs. \\
\hline \multicolumn{9}{|l|}{ Government debt sustainability } \\
\hline General government gross debt (percent of GDP) & $30.0[70.0]$ & 30 & $69.7[30.3]$ & 33 & $18.2[81.8]$ & 33 & $13.5[86.5]$ & 37 \\
\hline Primary balance (percent of GDP) & $37.9[62.1]$ & 29 & $48.5[51.5]$ & 33 & $63.6[36.4]$ & 33 & $77.8[22.2]$ & 36 \\
\hline Cyclically-adjusted balance (percent of potential GDP) & $32.3[64.5]$ & 31 & $55.9[38.2]$ & 34 & $50.0[50.0]$ & 34 & $51.4[45.7]$ & 35 \\
\hline Fiscal balance (percent of GDP) & $22.6[74.2]$ & 31 & $38.2[58.8]$ & 34 & $55.9[44.1]$ & 34 & 78.4 [18.9] & 37 \\
\hline $\begin{array}{l}\text { General government gross debt } \\
\quad \text { (percent of average tax revenues) }\end{array}$ & $30.0[70.0]$ & 30 & $69.7[30.3]$ & 33 & $18.2[81.8]$ & 33 & $13.9[86.1]$ & 36 \\
\hline Fiscal balance (percent of average tax revenues) & $22.6[77.4]$ & 31 & $38.2[61.8]$ & 34 & $55.9[44.1]$ & 34 & $81.1[18.9]$ & 37 \\
\hline Sustainability gap, fiscal balance (percent of GDP) & $51.7[48.3]$ & 29 & $35.3[61.8]$ & 34 & $67.6[29.4]$ & 34 & $91.9[8.1]$ & 37 \\
\hline $\begin{array}{l}\text { Sustainability gap, primary balance } \\
\text { country-specific conditions (percent of GDP) }\end{array}$ & $37.9[62.1]$ & 29 & $48.5[51.5]$ & 33 & $63.6[36.4]$ & 33 & $77.1[22.9]$ & 35 \\
\hline $\begin{array}{l}\text { Sustainability gap, primary balance } \\
\text { historical conditions (percent of GDP) }\end{array}$ & $37.9[62.1]$ & 29 & $48.5[51.5]$ & 33 & $63.6[36.4]$ & 33 & $77.1[22.9]$ & 35 \\
\hline $\begin{array}{l}\text { Sustainability gap, primary balance } \\
\text { current conditions (percent of GDP) }\end{array}$ & $22.7[77.3]$ & 22 & $42.9[53.6]$ & 28 & 70.4 [29.6] & 27 & $76.5[17.6]$ & 34 \\
\hline $\begin{array}{l}\text { Sustainability gap, primary balance } \\
\text { stressed conditions (percent of GDP) }\end{array}$ & $37.9[62.1]$ & 29 & $48.5[51.5]$ & 33 & $63.6[36.4]$ & 33 & $77.1[22.9]$ & 35 \\
\hline $\begin{array}{l}\text { Sustainability gap, primary balance } \\
\text { benign conditions (percent of GDP) }\end{array}$ & $37.9[62.1]$ & 29 & $48.5[51.5]$ & 33 & $63.6[36.4]$ & 33 & $77.1[22.9]$ & 35 \\
\hline \multicolumn{9}{|l|}{ Balance sheet composition } \\
\hline $\begin{array}{l}\text { General government debt in foreign currency } \\
\text { (percent of total) }\end{array}$ & $\ldots[\ldots]$ & 6 & $72.7[0.0]$ & 11 & $70.0[20.0]$ & 10 & $33.3[41.7]$ & 12 \\
\hline Debt securities held by nonresidents (percent of total) & $\ldots[\ldots]$ & 0 & $\ldots[\ldots]$ & 0 & $\ldots[\ldots]$ & 0 & $56.7[36.7]$ & 30 \\
\hline $\begin{array}{l}\text { General government debt held by nonresidents } \\
\text { (percent of total) }\end{array}$ & $\ldots[\ldots]$ & 7 & $33.3[66.7]$ & 12 & $16.7[83.3]$ & 12 & $39.3[60.7]$ & 28 \\
\hline $\begin{array}{l}\text { Concessional external debt stocks } \\
\text { (percent of general government gross debt) }\end{array}$ & $\ldots[\ldots]$ & 0 & $\ldots[\ldots]$ & 0 & $\ldots[\ldots]$ & 0 & $\ldots[\ldots]$ & 0 \\
\hline Sovereign debt average maturity (years) & $\ldots[\ldots]$ & 0 & $\ldots[\ldots]$ & 0 & $\ldots[\ldots]$ & 0 & $30.0[70.0]$ & 20 \\
\hline $\begin{array}{l}\text { Central government debt maturing in } \\
12 \text { months or less (percent of GDP) } 1 /\end{array}$ & $\ldots[\ldots]$ & 0 & $\ldots[\ldots]$ & 0 & $\ldots[\ldots]$ & 0 & $54.5[39.4]$ & 33 \\
\hline \multicolumn{9}{|l|}{ External and private sector debt } \\
\hline Total external debt stocks (percent of GDP) $2 /$ & $\ldots[\ldots]$ & 0 & $9.4[90.6]$ & 32 & $9.4[90.6]$ & 32 & $50.0[50.0]$ & 32 \\
\hline External debt in foreign currency (percent of total) & $\ldots[\ldots]$ & 0 & $\ldots[\ldots]$ & 2 & $\ldots[\ldots]$ & 2 & $\ldots[\ldots]$ & 5 \\
\hline Private external debt stocks (percent of GDP) $2 /$ & $\ldots[\ldots]$ & 0 & $12.5[87.5]$ & 32 & $31.3[68.8]$ & 32 & $75.0[25.0]$ & 32 \\
\hline Domestic credit to private sector (percent of GDP) & $8.6[91.4]$ & 35 & $25.7[74.3]$ & 35 & $22.9[77.1]$ & 35 & $50.0[50.0]$ & 36 \\
\hline Short-term external debt stocks (percent of total) $2 /$ & $\ldots[\ldots]$ & 0 & $40.6[59.4]$ & 32 & $59.4[40.6]$ & 32 & $68.8[28.1]$ & 32 \\
\hline $\begin{array}{l}\text { Short-term external debt stocks } \\
\quad \text { (percent of reserves) } 2 /\end{array}$ & $\ldots[\ldots]$ & 0 & $6.3[93.8]$ & 32 & $46.9[53.1]$ & 32 & $78.1[21.9]$ & 32 \\
\hline Total external debt stocks (percent of reserves) 2/ & $\ldots[\ldots]$ & 0 & $3.1[96.9]$ & 32 & $40.6[59.4]$ & 32 & $75.0[25.0]$ & 32 \\
\hline $\begin{array}{l}\text { Total external debt stocks } \\
\quad \text { (percent of reserves excluding gold) } 2 /\end{array}$ & $\ldots[\ldots]$ & 0 & $3.1[96.9]$ & 32 & $28.1[71.9]$ & 32 & $75.0[25.0]$ & 32 \\
\hline \multicolumn{9}{|l|}{ Market perception } \\
\hline 5-year sovereign CDS spreads (basis points) & $\ldots[\ldots]$ & 0 & $\ldots[\ldots]$ & 0 & $\ldots[\ldots]$ & 0 & $0.0[100.0]$ & 20 \\
\hline $\begin{array}{l}\text { Foreign currency long-term sovereign debt ratings } \\
\quad \text { (index ranging } 1-21 \text { [best]) }\end{array}$ & $45.2[41.9]$ & 31 & 7.9 [63.2] & 38 & $44.7[39.5]$ & 38 & $52.5[20.0]$ & 40 \\
\hline
\end{tabular}

Note: Share shows the percent shares of countries with negative change $\left(\Delta^{-}\right)$and with positive change $(\Delta+)$ (in bracket) over the denoted periods. The percent shares are not computed, when the number of observations is less than 10. A negative (positive) change refers to a change at least by 0.1 percenrage point for variables expressed in percent (or 10 basis points for CDS spreads). For sovereign debt average maturity and long-term sovereign debt ratings, a change by 0.1 percent is used. Because of small or no change in some indicators, they do not always add up to 100. 1/ Data for 2015 are used, instead of 2016. 2/ Data for 2011 are used, instead of 2007. 3/ Data for 2003 are used, instead of 2000 . 
Table A7. Changes in fiscal space, share of countries, EMDEs

\begin{tabular}{|c|c|c|c|c|c|c|c|c|}
\hline & \multicolumn{2}{|c|}{$1995-2016$} & \multicolumn{2}{|c|}{$2000-07$} & \multicolumn{2}{|l|}{$2000-16$} & \multicolumn{2}{|c|}{$2007-16$} \\
\hline & Share & & Share & & Share & & Share & \\
\hline & $\Delta-[\Delta+]$ & Obs. & $\Delta-[\Delta+]$ & Obs. & $\Delta-[\Delta+]$ & Obs. & $\Delta-[\Delta+]$ & Obs. \\
\hline \multicolumn{9}{|l|}{ Government debt sustainability } \\
\hline General government gross debt (percent of GDP) & $52.7[47.3]$ & 55 & 79.8 [20.2] & 124 & $61.8[37.4]$ & 123 & $29.0[71.0]$ & 145 \\
\hline Primary balance (percent of GDP) & $69.9[30.1]$ & 93 & 39.8 [59.4] & 133 & $66.7[31.8]$ & 132 & $74.5[24.1]$ & 145 \\
\hline Cyclically-adjusted balance (percent of potential GDP) & $65.4[32.1]$ & 81 & $35.1[60.4]$ & 111 & $64.0[36.0]$ & 111 & 69.5 [29.7] & 118 \\
\hline Fiscal balance (percent of GDP) & $61.9[36.1]$ & 97 & 29.3 [67.9] & 140 & $61.2[37.4]$ & 139 & $75.3[22.0]$ & 150 \\
\hline $\begin{array}{l}\text { General government gross debt } \\
\quad \text { (percent of average tax revenues) }\end{array}$ & $52.7[47.3]$ & 55 & $79.8[20.2]$ & 124 & $62.6[37.4]$ & 123 & $29.2[70.8]$ & 144 \\
\hline Fiscal balance (percent of average tax revenues) & $62.9[37.1]$ & 97 & $30.7[69.3]$ & 140 & $62.6[37.4]$ & 139 & $77.2[22.1]$ & 149 \\
\hline Sustainability gap, fiscal balance (percent of GDP) & $85.4[14.6]$ & 96 & 20.7 [79.3] & 135 & $62.7[35.8]$ & 134 & $88.7[11.3]$ & 150 \\
\hline $\begin{array}{l}\text { Sustainability gap, primary balance } \\
\text { country-specific conditions (percent of GDP) }\end{array}$ & $76.6[23.4]$ & 47 & $40.9[59.1]$ & 66 & $72.7[25.8]$ & 66 & $79.2[20.8]$ & 72 \\
\hline $\begin{array}{l}\text { Sustainability gap, primary balance } \\
\text { historical conditions (percent of GDP) }\end{array}$ & 76.6 [23.4] & 47 & 40.9 [59.1] & 66 & $72.7[25.8]$ & 66 & $79.2[20.8]$ & 72 \\
\hline $\begin{array}{l}\text { Sustainability gap, primary balance } \\
\text { current conditions (percent of GDP) }\end{array}$ & $\ldots[\ldots]$ & 9 & 20.5 [79.5] & 44 & $50.0[45.5]$ & 44 & 92.5 [7.5] & 67 \\
\hline $\begin{array}{l}\text { Sustainability gap, primary balance } \\
\text { stressed conditions (percent of GDP) }\end{array}$ & $76.6[23.4]$ & 47 & $40.9[59.1]$ & 66 & $72.7[25.8]$ & 66 & $79.2[20.8]$ & 72 \\
\hline $\begin{array}{l}\text { Sustainability gap, primary balance } \\
\text { benign conditions (percent of GDP) }\end{array}$ & $76.6[23.4]$ & 47 & $40.9[59.1]$ & 66 & $72.7[25.8]$ & 66 & $79.2[20.8]$ & 72 \\
\hline \multicolumn{9}{|l|}{ Balance sheet composition } \\
\hline $\begin{array}{l}\text { General government debt in foreign currency } \\
\text { (percent of total) }\end{array}$ & $\ldots[\ldots]$ & 1 & $\ldots[\ldots]$ & 2 & $\ldots[\ldots]$ & 2 & $\ldots[\ldots]$ & 3 \\
\hline Debt securities held by nonresidents (percent of total) & $\ldots[\ldots]$ & 0 & $\ldots[\ldots]$ & 0 & $\ldots[\ldots]$ & 0 & 36.4 [45.5] & 11 \\
\hline $\begin{array}{l}\text { General government debt held by nonresidents } \\
\text { (percent of total) }\end{array}$ & $\ldots[\ldots]$ & 1 & $\ldots[\ldots]$ & 1 & $\ldots[\ldots]$ & 1 & $52.2[47.8]$ & 23 \\
\hline $\begin{array}{l}\text { Concessional external debt stocks } \\
\text { (percent of general government gross debt) } 1 /\end{array}$ & $75.7[24.3]$ & 37 & 60.4 [38.5] & 96 & $72.7[23.2]$ & 99 & 69.9 [29.2] & 113 \\
\hline Sovereign debt average maturity (years) & $90.0[10.0]$ & 10 & $54.5[45.5]$ & 22 & $47.8[52.2]$ & 23 & $57.9[42.1]$ & 38 \\
\hline $\begin{array}{l}\text { Central government debt maturing in } \\
12 \text { months or less (percent of GDP) 2/ }\end{array}$ & $\ldots[\ldots]$ & 0 & $\ldots[\ldots]$ & 0 & $\ldots[\ldots]$ & 0 & $23.8[71.4]$ & 84 \\
\hline \multicolumn{9}{|l|}{ External and private sector debt } \\
\hline Total external debt stocks (percent of GDP) & $50.9[49.1]$ & 55 & $75.0[25.0]$ & 120 & $50.0[50.0]$ & 58 & $25.8[74.2]$ & 62 \\
\hline External debt in foreign currency (percent of total) & $\ldots[\ldots]$ & 0 & $\ldots[\ldots]$ & 2 & $\ldots[\ldots]$ & 2 & $50.0[50.0]$ & 18 \\
\hline Private external debt stocks (percent of GDP) & $23.6[69.1]$ & 55 & $38.3[27.5]$ & 120 & $25.9[67.2]$ & 58 & $29.0[64.5]$ & 62 \\
\hline Domestic credit to private sector (percent of GDP) & $7.3[92.7]$ & 123 & $25.7[72.1]$ & 140 & $14.7[85.3]$ & 129 & $17.3[82.0]$ & 133 \\
\hline Short-term external debt stocks (percent of total) & $40.0[56.4]$ & 55 & $33.1[62.8]$ & 121 & $38.6[61.4]$ & 57 & $57.4[36.1]$ & 61 \\
\hline $\begin{array}{l}\text { Short-term external debt stocks } \\
\quad \text { (percent of reserves) }\end{array}$ & $55.6[44.4]$ & 54 & $67.8[28.7]$ & 115 & $59.6[38.6]$ & 57 & $49.2[47.5]$ & 61 \\
\hline Total external debt stocks (percent of reserves) & $74.5[25.5]$ & 55 & 83.5 [16.5] & 115 & $77.6[22.4]$ & 58 & $32.3[67.7]$ & 62 \\
\hline $\begin{array}{l}\text { Total external debt stocks } \\
\quad \text { (percent of reserves excluding gold) }\end{array}$ & $74.5[25.5]$ & 55 & $83.5[16.5]$ & 115 & $74.1[25.9]$ & 58 & $30.6[69.4]$ & 62 \\
\hline \multicolumn{9}{|l|}{ Market perception } \\
\hline 5-year sovereign CDS spreads (basis points) & $\ldots[\ldots]$ & 0 & $93.3[0.0]$ & 15 & $66.7[33.3]$ & 15 & 3.0 [97.0] & 33 \\
\hline $\begin{array}{l}\text { Foreign currency long-term sovereign debt ratings } \\
\quad \text { (index ranging } 1-21 \text { [best]) }\end{array}$ & $36.0[64.0]$ & 25 & $26.2[60.0]$ & 65 & 33.3 [61.9] & 63 & 51.7 [32.6] & 89 \\
\hline
\end{tabular}

Note: Share shows the percent shares of countries with negative change $\left(\Delta^{-}\right)$and with positive change $(\Delta+)$ (in bracket) over the denoted periods. The percent shares are not computed, when the number of observations is less than 10. A negative (positive) change refers to a change at least by 0.1 percenrage point for variables expressed in percent (or 10 basis points for CDS spreads). For sovereign debt average maturity and long-term sovereign debt ratings, a change by 0.1 percent is used. Because of small or no change in some indicators, they do not always add up to 100. 1/ Data for 2015 are used, instead of 2016. 2/ Data for 2011 are used, instead of 2007. 
Table A8. List of crisis episodes

\begin{tabular}{|c|c|c|c|c|c|c|c|c|c|c|c|c|c|c|c|}
\hline \multicolumn{4}{|c|}{ Advanced economies (25) } & \multicolumn{12}{|l|}{ EMDEs (94) } \\
\hline & $\begin{array}{r}\text { Banking } \\
\text { crises }\end{array}$ & $\begin{array}{r}\text { Currency } \\
\text { crises }\end{array}$ & $\begin{array}{r}\text { Debt } \\
\text { distress }\end{array}$ & & $\begin{array}{r}\text { Banking } \\
\text { crises }\end{array}$ & $\begin{array}{r}\text { Currency } \\
\text { crises }\end{array}$ & $\begin{array}{r}\text { Debt } \\
\text { distress }\end{array}$ & & $\begin{array}{r}\text { Banking } \\
\text { crises }\end{array}$ & $\begin{array}{r}\text { Currency } \\
\text { crises }\end{array}$ & $\begin{array}{r}\text { Debt } \\
\text { distress }\end{array}$ & & $\begin{array}{r}\text { Banking } \\
\text { crises }\end{array}$ & $\begin{array}{r}\text { Currency } \\
\text { crises }\end{array}$ & $\begin{array}{r}\text { Deb } \\
\text { distress }\end{array}$ \\
\hline Austria & 2008 & & & Albania & 1994 & 1997 & & Gabon & & 1994 & 2002 & Pakistan & & & 1999 \\
\hline Belgium & 2008 & & & Algeria & & 1994 & & Gambia, The & & 2003 & & Papua New Guinea & & 1995 & \\
\hline Czech Republic & 1996 & & & Angola & & 1996 & & Georgia & & 1999 & & Paraguay & 1995 & 2002 & \\
\hline Denmark & 2008 & 1993 & & Argentina & 1995, 2001 & 2002 & 2001 & Ghana & & 1993, 2000, 2009 & & Philippines & 1997 & 1998 & \\
\hline Finland & & 1993 & & Armenia & 1994 & & & Grenada & & & 2004 & Romania & & 1996 & \\
\hline France & 2008 & & & Azerbajan & 1995 & & & Guinea & 1993 & 2005 & & Russian Federation & 1998,2008 & 1998 & 1998 \\
\hline Germany & 2008 & & & Belarus & 1995 & 1997, 2009 & & Guinea-Bissau & 1995 & 1994 & & Sao Tome \& Principe & & 1997 & \\
\hline Greece & 2008 & & 2012 & Benin & & 1994 & & Guyana & 1993 & & & Senegal & & 1994 & \\
\hline Iceland & 2008 & 2008 & & Bolivia & 1994 & & & Haiti & 1994 & 2003 & & Serbia & & 2000 & \\
\hline Ireland & 2008 & & & Brazil & 1994 & 1999 & 2002 & Hungary & 2008 & & & Seychelles & & 2008 & 2008 \\
\hline Italy & 2008 & 1995 & & Bulgaria & 1996 & 1996 & & India & 1993 & & & Sierra Leone & & 1998 & \\
\hline Japan & 1997 & & & Burkina Faso & & 1994 & & Indonesia & 1997 & 1998 & 1998 & South Africa & & & 1993 \\
\hline Korea, Rep. & 1997 & 1997,2008 & & Burundi & 1994 & & & Iran, Islamic Rep. & & 1993,2000 & & Sri Lanka & & & 1996 \\
\hline Latvia & 1995,2008 & & & Cabo Verde & 1993 & & & Jamaica & 1996 & & 2010 & Sudan & & 1993 & \\
\hline Lithuania & 1995 & & & Cameroon & 1995 & 1994 & & Kazakhstan & 2008 & 1999 & & Suriname & & 1995, 2001 & \\
\hline Luxembourg & 2008 & & & Central African Rep. & 1995 & 1994 & & Kenya & & 1993 & & Swaziland & 1995 & & \\
\hline Netherlands & 2008 & & & Chad & & 1994 & & Kyrgyz Republic & 1995 & 1997 & & Tajkistan & & 1999 & \\
\hline Portugal & 2008 & & & China & 1998 & & & Lao PDR & & 1997 & & Thailand & 1997 & 1998 & \\
\hline Slovak Republic & 1998 & & & Colombia & 1998 & & & Libya & & 2002 & & Togo & 1993 & 1994 & \\
\hline Slovenia & 2008 & & & Comoros & & 1994 & & Macedonia, FYR & 1993 & & & Turkey & 2000 & 2001 & 2001 \\
\hline Spain & 2008 & 1995 & & Congo, Dem. Rep. & 1994 & 1994,2009 & & Madagascar & & 1994,2004 & & Turkmenistan & & 2008 & \\
\hline Sweden & 2008 & & & Congo, Rep. & & 1994 & & Malawi & & 1994 & & Uganda & 1994 & & \\
\hline Switzerland & 2008 & & & Costa Rica & 1994 & & & Malaysia & 1997 & 1998 & & Ukraine & 1998,2008 & 1998, 2009 & 1998 \\
\hline United Kingdom & 2007 & & & Cote d'Ivoire & & 1994 & 2000 & Mali & & 1994 & & Uruguay & 2002 & 2002 & 2003 \\
\hline \multirow[t]{8}{*}{ United States } & 2007 & & & Croatia & 1998 & & 1993 & Mauritania & & 1993 & & Uzbekistan & & 2000 & \\
\hline & & & & Dominica & & & 2002 & Mexico & 1994 & 1995 & & Venezuela, RB & 1994 & $1994,2002,2010$ & 1998, 2005 \\
\hline & & & & Dominican Republic & 2003 & 2003 & 2005 & Moldova & & 1999 & 2002 & Vietnam & 1997 & & \\
\hline & & & & Ecuador & 1998 & 1999 & 1999,2008 & Mongolia & 2008 & 1997 & & Yemen, Rep. & 1996 & 1995 & \\
\hline & & & & Equatorial Guinea & & 1994 & & Myanmar & & 2001,2007 & & Zambia & 1995 & 1996, 2009 & \\
\hline & & & & Eritrea & 1993 & & & Nicaragua & 2000 & & & Zimbabwe & 1995 & 2003 & \\
\hline & & & & Ethiopia & & 1993 & & Niger & & 1994 & & & & & \\
\hline & & & & Fiji & & 1998 & & Nigeria & 2009 & 1997 & 2001 & & & & \\
\hline
\end{tabular}

Note: Financial crises are based on Gourinchas and Obstfeld (2012) and Laeven and Valencia (2013). Only the crisis episodes considered in Figure 6 and Tables A9 and A10 are listed. episodes in EMDEs. 
Table A9. Changes in fiscal space during financial crises, before vs after

\begin{tabular}{|c|c|c|c|c|c|c|c|c|c|c|c|}
\hline & \multicolumn{2}{|c|}{ Before } & \multicolumn{2}{|c|}{ After } & \multirow{2}{*}{$\begin{array}{c}\text { Difference } \\
\text { (P-value) }\end{array}$} & & \multicolumn{2}{|c|}{ Before } & \multicolumn{2}{|c|}{ After } & \multirow{2}{*}{$\begin{array}{c}\text { Difference } \\
(\mathrm{P}-\mathrm{value})\end{array}$} \\
\hline & Mean & $\mathrm{N}$ & Mean & $\mathrm{N}$ & & & Mean & $\mathrm{N}$ & Mean & $\mathrm{N}$ & \\
\hline Advanced economies & & & & & & EMDEs & & & & & \\
\hline \multicolumn{12}{|c|}{ General government gross debt (percent of GDP) } \\
\hline Banking crises & 48.6 & 45 & 65.6 & 46 & 0.01 & Banking crises & 37.0 & 37 & 52.7 & 54 & $\mathbf{0 . 0 3}$ \\
\hline Currency crises & 47.8 & 13 & 63.3 & 14 & 0.26 & Currency crises & 68.9 & 77 & 71.2 & 103 & 0.79 \\
\hline Debt distress & & & & & & Debt distress & 72.6 & 34 & 70.1 & 42 & 0.75 \\
\hline \multicolumn{12}{|c|}{ Primary balance (percent of GDP) } \\
\hline Banking crises & 0.7 & 45 & -4.8 & 46 & $\mathbf{0 . 0 0}$ & Banking crises & 0.3 & 66 & -0.4 & 82 & 0.34 \\
\hline Currency crises & 0.9 & 14 & -0.8 & 14 & 0.23 & Currency crises & -8.4 & 110 & -0.2 & 131 & 0.09 \\
\hline Debt distress & & & & & & Debt distress & 1.7 & 39 & 3.0 & 46 & 0.19 \\
\hline \multicolumn{12}{|c|}{ Sustainability gap, primary balance, historical conditions (percent of GDP) } \\
\hline Banking crises & 0.9 & 45 & -4.6 & 46 & 0.00 & Banking crises & 2.3 & 51 & 1.9 & 59 & 0.66 \\
\hline Currency crises & 1.1 & 14 & -0.6 & 14 & 0.22 & Currency crises & 0.1 & 59 & 2.3 & 70 & 0.00 \\
\hline Debt distress & & & & & & Debt distress & 2.9 & 31 & 3.5 & 38 & 0.62 \\
\hline \multicolumn{12}{|c|}{ Sustainability gap, primary balance, current conditions (percent of GDP) } \\
\hline Banking crises & 3.0 & 40 & -8.0 & 41 & 0.00 & Banking crises & 2.3 & 26 & -2.7 & 41 & 0.04 \\
\hline Currency crises & -1.6 & 12 & -1.8 & 12 & 0.93 & Currency crises & 0.0 & 32 & 3.1 & 45 & 0.07 \\
\hline Debt distress & & & & & & Debt distress & 1.8 & 20 & 0.5 & 28 & 0.68 \\
\hline \multicolumn{12}{|c|}{ Sovereign debt average maturity (years) } \\
\hline Banking crises & 7.9 & 30 & 8.2 & 30 & 0.61 & Banking crises & 11.7 & 32 & 11.4 & 44 & 0.83 \\
\hline Currency crises & & & & & & Currency crises & 13.8 & 32 & 12.4 & 39 & 0.30 \\
\hline Debt distress & & & & & & Debt distress & 15.9 & 25 & 12.2 & 30 & $\mathbf{0 . 0 3}$ \\
\hline \multicolumn{12}{|c|}{ Total external debt stocks, change (percent points of GDP) } \\
\hline Banking crises & 49.7 & 38 & 11.4 & 39 & 0.18 & Banking crises & 1.1 & 96 & 1.1 & 105 & 0.99 \\
\hline Currency crises & & & & & & Currency crises & 2.0 & 150 & -3.5 & 153 & 0.15 \\
\hline Debt distress & & & & & & Debt distress & 1.6 & 40 & -3.0 & 43 & 0.17 \\
\hline \multicolumn{12}{|c|}{ Domestic credit to private sector, change (percentage points of GDP) } \\
\hline Banking crises & 5.8 & 47 & -0.6 & 48 & 0.01 & Banking crises & 2.8 & 94 & -3.0 & 104 & 0.00 \\
\hline Currency crises & 1.8 & 14 & -4.8 & 14 & 0.37 & Currency crises & 0.9 & 141 & -1.9 & 156 & $\mathbf{0 . 0 0}$ \\
\hline Debt distress & & & & & & Debt distress & 1.0 & 44 & -1.1 & 48 & 0.06 \\
\hline \multicolumn{12}{|c|}{ Short-term external debt stocks (percent of total) } \\
\hline Banking crises & 41.0 & 38 & 38.3 & 40 & 0.46 & Banking crises & 14.7 & 99 & 11.5 & 108 & 0.10 \\
\hline Currency crises & & & & & & Currency crises & 14.6 & 152 & 12.6 & 154 & 0.17 \\
\hline Debt distress & & & & & & Debt distress & 14.8 & 40 & 12.8 & 44 & 0.40 \\
\hline \multicolumn{12}{|c|}{ Foreign currency long-term sovereign debt ratings (index ranging 1-21 [best]) } \\
\hline Banking crises & 19.2 & 46 & 17.8 & 49 & 0.05 & Banking crises & 10.9 & 48 & 8.7 & 59 & 0.00 \\
\hline Currency crises & 18.5 & 14 & 16.5 & 14 & 0.04 & Currency crises & 9.2 & 50 & 7.0 & 64 & 0.00 \\
\hline Debt distress & & & & & & Debt distress & 7.9 & 32 & 5.7 & 36 & 0.00 \\
\hline
\end{tabular}

Note: Mean value is the average of each variable before and after the onset of crises. The period coverage is two years, meaning that averages for "Before" cover $t-2$ and $t-1$ and those for "After" do $t+1$ and $t+2$. $N$ is the number of observations used to compute mean values. P-values of Wald tests where the null hypothesis is that the two mean values are equal are reported. The values in bold show that the two means are statistically significantly different at least at the 10 percent level. When the number of observations is less than five in a year, that year is excluded from the calculation. 
Table A10. Changes in fiscal space, pre-crisis vs current period

\begin{tabular}{|c|c|c|c|c|c|c|c|c|c|c|c|}
\hline & \multicolumn{2}{|c|}{ Before crisis } & \multicolumn{2}{|c|}{ Current period } & \multirow{2}{*}{$\begin{array}{c}\text { Difference } \\
\text { (P-value) }\end{array}$} & & \multicolumn{2}{|c|}{ Before crisis } & \multicolumn{2}{|c|}{ Current period } & \multirow{2}{*}{$\begin{array}{r}\text { Difference } \\
\text { (P-value) }\end{array}$} \\
\hline & Mean & $\mathrm{N}$ & Mean & $\mathrm{N}$ & & & Mean & $\mathrm{N}$ & Mean & $\mathrm{N}$ & \\
\hline Advanced economies & & & & & & EMDEs & & & & & \\
\hline \multicolumn{12}{|c|}{ General government gross debt (percent of GDP) } \\
\hline Banking crises & 48.6 & 45 & 71.4 & 37 & 0.01 & Banking crises & 37.0 & 37 & 52.7 & 148 & 0.00 \\
\hline Currency crises & 47.8 & 13 & 71.4 & 37 & 0.08 & Currency crises & 68.9 & 77 & 52.7 & 148 & 0.03 \\
\hline Debt distress & & & 71.4 & 37 & & Debt distress & 72.6 & 34 & 52.7 & 148 & 0.00 \\
\hline \multicolumn{12}{|c|}{ Primary balance (percent of GDP) } \\
\hline Banking crises & 0.7 & 45 & 0.6 & 37 & 0.86 & Banking crises & 0.3 & 66 & -3.5 & 146 & $\mathbf{0 . 0 0}$ \\
\hline Currency crises & 0.9 & 14 & 0.6 & 37 & 0.81 & Currency crises & -8.4 & 110 & -3.5 & 146 & 0.31 \\
\hline Debt distress & & & 0.6 & 37 & & Debt distress & 1.7 & 39 & -3.5 & 146 & 0.00 \\
\hline \multicolumn{12}{|c|}{ Sustainability gap, primary balance, historical conditions (percent of GDP) } \\
\hline Banking crises & 0.9 & 45 & 1.0 & 35 & 0.93 & Banking crises & 2.3 & 51 & -2.0 & 72 & $\mathbf{0 . 0 0}$ \\
\hline Currency crises & 1.1 & 14 & 1.0 & 35 & 0.91 & Currency crises & 0.1 & 59 & -2.0 & 72 & $\mathbf{0 . 0 0}$ \\
\hline Debt distress & & & 1.0 & 35 & & Debt distress & 2.9 & 31 & -2.0 & 72 & $\mathbf{0 . 0 0}$ \\
\hline \multicolumn{12}{|c|}{ Sustainability gap, primary balance, current conditions (percent of GDP) } \\
\hline Banking crises & 3.0 & 40 & 1.6 & 34 & 0.07 & Banking crises & 2.3 & 26 & -3.0 & 70 & $\mathbf{0 . 0 0}$ \\
\hline Currency crises & -1.6 & 12 & 1.6 & 34 & 0.16 & Currency crises & 0.0 & 32 & -3.0 & 70 & 0.02 \\
\hline Debt distress & & & 1.6 & 34 & & Debt distress & 1.8 & 20 & -3.0 & 70 & 0.04 \\
\hline \multicolumn{12}{|c|}{ Sovereign debt average maturity (years) } \\
\hline Banking crises & 7.9 & 30 & 7.8 & 23 & 0.87 & Banking crises & 11.7 & 32 & 9.0 & 62 & 0.03 \\
\hline Currency crises & & & 7.8 & 23 & & Currency crises & 13.8 & 32 & 9.0 & 62 & 0.00 \\
\hline Debt distress & & & 7.8 & 23 & & Debt distress & 15.9 & 25 & 9.0 & 62 & 0.00 \\
\hline \multicolumn{12}{|c|}{ Total external debt stocks (percent of GDP) } \\
\hline Banking crises & 441.7 & 38 & 397.3 & 35 & 0.85 & Banking crises & 64.4 & 99 & 59.7 & 67 & 0.54 \\
\hline Currency crises & & & 397.3 & 35 & & Currency crises & 71.0 & 150 & 59.7 & 67 & 0.20 \\
\hline Debt distress & & & 397.3 & 35 & & Debt distress & 54.1 & 40 & 59.7 & 67 & 0.38 \\
\hline \multicolumn{12}{|c|}{ Domestic credit to private sector (percent of GDP) } \\
\hline Banking crises & 114.0 & 48 & 110.7 & 36 & 0.78 & Banking crises & 29.4 & 97 & 43.0 & 134 & 0.00 \\
\hline Currency crises & 115.8 & 14 & 110.7 & 36 & 0.82 & Currency crises & 19.3 & 149 & 43.0 & 134 & 0.00 \\
\hline Debt distress & & & 110.7 & 36 & & Debt distress & 24.9 & 45 & 43.0 & 134 & $\mathbf{0 . 0 0}$ \\
\hline \multicolumn{12}{|c|}{ Short-term external debt stocks (percent of total) } \\
\hline Banking crises & 41.0 & 38 & 36.9 & 35 & 0.28 & Banking crises & 14.7 & 99 & 14.4 & 67 & 0.88 \\
\hline Currency crises & & & 36.9 & 35 & & Currency crises & 14.6 & 152 & 14.4 & 67 & 0.90 \\
\hline Debt distress & & & 36.9 & 35 & & Debt distress & 14.8 & 40 & 14.4 & 67 & 0.85 \\
\hline \multicolumn{12}{|c|}{ Foreign currency long-term sovereign debt ratings (index ranging 1-21 [best]) } \\
\hline Banking crises & 19.2 & 46 & 17.4 & 40 & 0.01 & Banking crises & 10.9 & 48 & 9.8 & 99 & 0.04 \\
\hline Currency crises & 18.5 & 14 & 17.4 & 40 & 0.12 & Currency crises & 9.2 & 50 & 9.8 & 99 & 0.30 \\
\hline Debt distress & & & 17.4 & 40 & & Debt distress & 7.9 & 32 & 9.8 & 99 & 0.00 \\
\hline
\end{tabular}

Note: Mean value is the average of each variable over two years before the crises (t-2 and t-1) and in 2016 (for the current period). $\mathrm{N}$ is the number of observations used to compute mean values. P-values of Wald tests where the null hypothesis is that the two mean values are equal are reported. The values in bold show that the two means are statistically significantly different at least at the 10 percent level. When the number of observations is less than five in a year, that year is excluded from the calculation. 
Table A11. Changes in fiscal space over oil price plunges

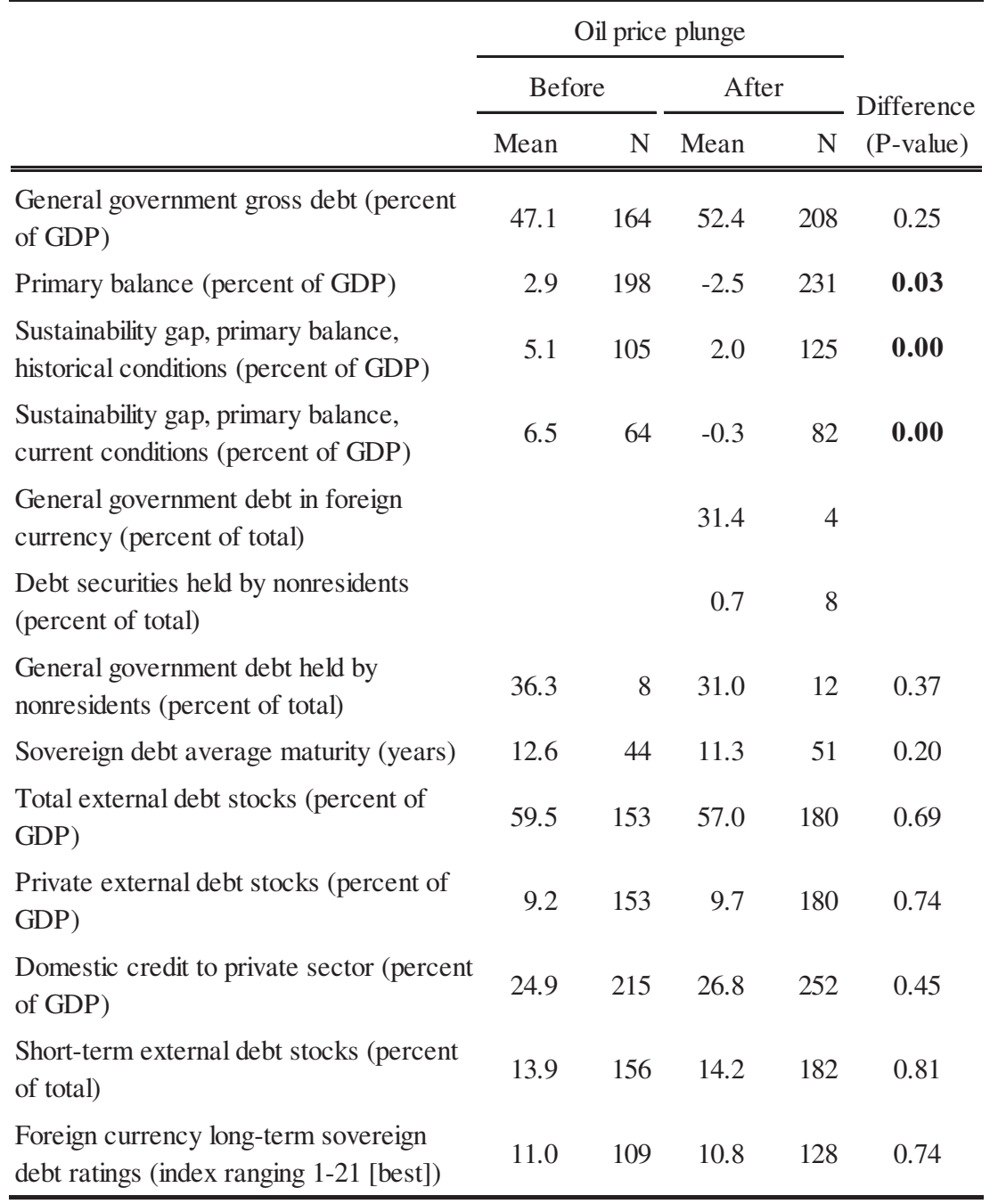

Note: Mean value is the average of each variable before and after oil price plunges. The period coverage is two years, meaning that averages for "Before" cover $t-2$ and $\mathrm{t}-1$ and those for "After" do $\mathrm{t}+1$ and $\mathrm{t}+2 . \mathrm{N}$ is the number of observations used to compute mean values. P-values of Wald tests where the null hypothesis is that the two mean values are equal are reported. The values in bold show that the two means are statistically significantly different at least at the 10 percent level. When the number of observations is less than five in a year, that year is excluded from the calculation. 